\title{
DOE/PC/94063--T6
}

QUARTERLY TECHNICAL PROGRESS REPORT

AND KEY PERSONNEL STAFFING REPORT

NUMBER 6

\section{PRODUCTION AND SCREENING OF CARBON PRODUCTS PRECURSORS FROM COAL}

\author{
CARBON PRODUCTS CONSORTIUM
}

CONTRACT NO. DE-AC22-95PC94063

\section{REPORTING PERIOD:}

April 1, 1996 to June 30, 1996

Submitted to:

AAD Document Control Center

U.S. Department of Energy

Pittsburgh Energy Technology Center

PO Box 10940, MS 921-143

Pittsburgh, PA 15236-0940

Submitted by:

West Virginia University Research Corporation on behalf of West Virginia University

617 N. Spruce Street

Morgantown, WV 26506

July, 1996 


\section{DISCLAMMER}

Portions of this document may be illegible in electronic image products. Images are produced from the best available original document. 


\section{DISCLAIMER}

This report was prepared as an account of work sponsored by an agency of the United States Government. Neither the United States Government nor any agency thereof, nor any of their employees, makes any warranty, express or implied, or assumes any legal liability or responsibility for the accuracy, completeness, or usefulness of any information, apparatus, product, or process disclosed, or represents that its use would not infringe privately owned rights. Reference herein to any specific commercial product, process, or service by trade name, trademark, manufacturer, or otherwise does not necessarily constitute or imply its endorsement, recommendation, or favoring by the United States Government or any agency thereof. The views and opinions of authors expressed herein do not necessarily state or reflect those of the United States Government or any agency thereof. 


\section{TABLE OF CONTENTS}

Executive Summary $\ldots \ldots \ldots \ldots \ldots \ldots \ldots \ldots \ldots \ldots \ldots \ldots \ldots \ldots \ldots$

$1.0 \quad$ Project Planning and Administration $\ldots \ldots \ldots \ldots \ldots \ldots \ldots \ldots \ldots$

$2.0 \quad$ Consortium Administration and Reporting $\ldots \ldots \ldots \ldots \ldots \ldots \ldots \ldots$

$3.0 \quad$ Coal Extraction $\ldots \ldots \ldots \ldots \ldots \ldots \ldots \ldots \ldots \ldots \ldots \ldots \ldots \ldots$

$4.0 \quad$ Technical/Economic Evaluation of WVU Extraction Process $\ldots \ldots \ldots \ldots \ldots$

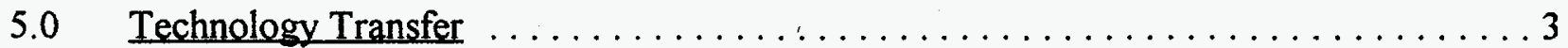

ATTACHMENTS $\ldots \ldots \ldots \ldots \ldots \ldots \ldots \ldots \ldots \ldots \ldots \ldots \ldots \ldots \ldots \ldots \ldots$ 


\section{Executive Summary}

This quarterly report covers activities during the period from April 1, 1996 through June 30, 1996. The first year of the project ended in February, 1996; however, the WVU research effort has continued on a no-cost extension of the original contract. Samples have been supplied to CPC participants so they could conduct their portions of the project as contracted through ORNL.

\subsection{Project Planning and Administration}

The purpose of Task 1.0 is to prepare and submit to the DOE, a Project Management plan for the WVU portion of the Carbon Products Consortium (CPC) workplan. This Management Plan was submitted to PETC on July 2, 1995. It has been accepted by the COTR and by the contracts management staff. Task 1.0 is complete.

\subsection{Consortium Administration and Reporting}

The purpose of Task 2.0 is to establish a Participants Agreement (PA) and a Proprietary Information Agreement (PIA) for members of the CPC, to facilitate communications between CPC participants and the COTR, and to help secure, maintain and manage CPC funds obtained under this contract.

The PA and the PIA were finalized on September 1, 1995. It was necessary to revise the PA to define the category of Affiliated Participant for an organization which does not sign the PA or the PIA, but is involved with the work of the CPC. A copy of the revised PA was included with Monthly Status Report No. 8, September 1, 1995 - September 30, 1995.

All monthly status and quarterly technical reports have been submitted as required by the contract. In addition to the required reports, regular communications with the COTR have been maintained.

Extensive efforts have been made to maintain funding through Fossil Energy, as well as, to broaden the base of funding for the work of the CPC. Programs are under development with the Office of Heavy Vehicle Technologies, the Office of Industrial Technologies (letter of June 20, 1996 to Charles Sorrell is attached), as well as, with the Navy Surface Warfare Center.

A copy of the final report which UCAR Carbon submitted to ORNL is included as an attachment to this report.

\subsection{Coal Extraction}

Under Task 3.0 and subtasks, WVU will provide a variety of types and sizes of samples of coal extracts to the industrial and national laboratory participants. In addition, green and calcined 
cokes will be developed. A summary of technical developments and other activities follow:

Koppers requested more coal-derived pitch for testing as a binder. WVU produced and delivered 500 grams of coal extract from West Virginia coal WVGS 13423. It is anticipated that Koppers will use the pitch in an anode test specimen.

ALCOA is continuing to qualify coal-based samples provided by WVU. Data has been received from Alcoa which summarize the latest findings of Alcoa on the WVU pitch materials. Indications are that the coke from the coal-derived pitch is quite suitable for use in aluminum production anodes.

A subcontract to WVU on AMOCO's Navy project was completed during the reporting period. Discussions on Amoco's pitch specifications for high-thermal conductivity fibers have started. Laboratory equipment is being assembled and made ready for operation.

FMI used the toluene-soluble pitch fraction from hydrogenated coal as an impregnation pitch for a 3-D carbon fiber preform. Another preform was impregnated with commercially available impregnation pitch. The two samples will be tested and compared after curing.

WVU has developed reactor systems to produce larger samples of carbon foams and is currently in full production of small test specimens. Evaluation of these specimens is being carried out at the NASA Langley Research Center. The coal-based carbon foam technology was developed concurrently with the CPC program.

The CPC group met with Vic Suski of the American Trucking Association (ATA) to discuss applications of carbon materials to heavy transportation vehicles. A prospectus has been prepared and submitted to ATA for use in establishing contacts with the U.S. Department of Transportation.

\subsection{Technical/Economic Evaluation of WVU Extraction Process}

WVU provided all requested information to the MTRE Corporation for their economic analysis of the coal extraction process. A draft of the MITRE report was received in mid July, 1995 and a revised version was received in September, 1995.

The MITRE report suggests several process changes whose implementation on a larger scale could substantially reduce the cost of the coal extraction process. MITRE finds that coal extract based calcined coke for anodes could be produced for approximately $\$ 177$ per ton. A February 1 article in the Financial Times reported that world aluminum production could be restricted by shortages of petroleum coke. The article said that coke prices have doubled the past year to between $\$ 240$ and $\$ 250$ a ton. This is because it is more profitable for refineries to make liquids than coke. MITRE also recommends research on the production of isotropic carbon fibers from coal extracts of unhydrogenated coal. Such fibers are in the $\$ 8$ to $\$ 10$ range and the market 
is expected to double in the near future.

\subsection{Technology Transfer}

Irv Lewis, John Zondlo, and Carl Irwin attended the Fossil Energy Materials Conference in Knoxville, Tennessee on May 14 and 15, 1996. Lewis and Zondlo presented a paper entitled, "Preparation and Evaluation of Coal Extracts as Precursors for Carbon and Graphite Products," and Irwin did a poster presentation entitled, "Overview of the Carbon Products Consortium." (Copies of both papers were included with Monthly Report \#16.)

A confidentiality agreement between BASF, Koppers and WVU is being negotiated. The agreement will facilitate discussions on scaling up production of certain types of coal-based extracts for further evaluation. BASF makes the solvent NMP which is used in the WVU coal extraction process.

There have been several planning meetings for the workshop entitled, "Applications of Carbon Products for Efficient Operation of Heavy Trucks, Buses, and Other Commercial Vehicles." The DOE Office of Heavy Vehicles Technologies is sponsoring the workshop which is scheduled for September 4-5, 1996 in Chicago. A copy of the latest workshop agenda is attached.

A letter (copy attached) has been sent to Jack L. White of the American Carbon Society proposing a workshop entitled, "Carbon Products and Critical Industries of the Future."

\section{ATTACHMENTS:}

1. Charles Sorrell Letter

2. Final Report from UCAR to ORNL

3. Most recent Workshop Agenda

4. Jack White letter 


\section{ATTACHMENT 1}

CHARLES SORRELL LETTER 
Carson Comoany Kooper industies CONOCO ALCOA

Amoco Poiymers toer Materials inc. Virginia University

Atfiliates:

ax Ridge Nationa Laboratory
June 20, 1996

Charles Sorrell

U.S. Department of Energy, EE-20

office of Industrial Technologies

1000 Independence Avenue, SW

Washington, D.C. 20585-0121

Fax No. (202) 586-3180

\section{Dear Charles:}

Since the May 21, 1996 meeting between representatives of the Carbon Products consortium (CPC) and the office of Industrial Technologies (OIT), I have been in touch with the CPC members concerning their views on future collaborations with the OIT. I can assure you we have a high level of interest in working with the OIT to develop a technology vision and research agenda to enhance and promote industrial uses of carbon products especially in the seven OIT designated industries of the future.

I think it is evident from the excellent presentations made on May 21 by the CPC industrial participants that there are compelling reasons for us to address issues such as feedstock quality and availability, loss of American technology to offshore interests, reducing costs, and transfer of advanced technology from defense to commercial applications.

The CPC has evolved partly in response to section 1304 of the National Energy Policy Act of 1992. This section authorizes an R\&D program on non-fuel uses of coal and, hopefully, will lead to production of high-value advanced materials derived from coals which may no longer be in demand for power generation.

As you know, we are currently organizing a workshop in cooperation with Jim Eberhardt and Sid Diamond of OTT to explore the applications of carbon products in heavy vehicle technologies. The end result of this workshop will be a MultiYear Program plan to help prioritize topics and organize resources for cooperative R\&D programs between industry, government, national labs, and academia. 
As you suggested, the CPC could undertake a series of workshops to develop vision statements and research agendas relative to the OIT's Industries of the Future Program. This approach would fit well with a primary goal of the CPC which is to promote interactions on selected topics among CPC participants, affiliates, and other interested colleagues.

on a related topic, we have proposed to the executive board of the American Carbon Society (ACS) that a workshop on the role of carbon products in critical industries of the future be planned for May 1998. The Acs workshop could largely reflect vision statements and research agendas which we would develop with the OIT over the next two years.

Thank you again for hosting our meeting on May 21 and for writing and circulating a report on the meeting to other OIT personnel who were unable to attend. We look forward to working with the OIT.

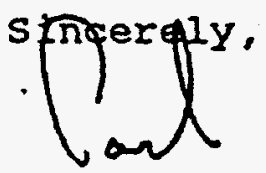

Caulton L. Irwin

(304) 293-7318 ×403 phone (304) 293-3749 fax 
ATTACHMENT 2

UCAR'S FINAL REPORT TO ORNL 


\title{
COAL PRECURSORS FOR PRODUCTION OF CARBON AND GRAPHITE PRODUCTS
}

\author{
FINAL REPORT
}

\author{
April 8, 1996 \\ Report Prepared by \\ I. C. Lewis, R T. Lewis, and H. K. Mayer \\ UCAR CARBON COMPANY INC. \\ Parma Technical Center \\ P. O. Box 6116 \\ Cleveland, Ohio 44101 \\ under Subcontract 62X-SR928C, WBS Element-UCAR-3 \\ for \\ OAK RIDGE NATIONAL LABORATORY \\ Oak Ridge, Tennessee 37831 \\ Managed by \\ LOCKHEED MARTIN ENERGY RESEARCH CORPORATION \\ for the \\ U.S. DEPARTMENT OF ENERGY \\ under contract DE-AC05-96OR22464
}


This report has been reproduced directly from the best available copy.

Available to DOE and DOE contractors from the Office of Scientific and Technical information, P.O. Box 62, Oak Ridge, TN 37831; prices available from (423) 576-8401.

Available to the public from the National Technical Information Service, U.S. Department of Commerce, 5285 Port Royal Rd., Springfield, VA 22161.

This report was prepared as an account of work sponsored by an agency of the United States Government. Neither the United States Government nor any agency thereof, nor any of their employees, makes any warranty, expressed or implied, or assumes any legal liability or responsibility for the accuracy, completeness, or usefulness of any information, apparatus, product, or process disclosed, or represents that its use would not infringe privately owned rights. Reference herein to any specific commercial product, process, or service by trade name, trademark, manufacturer, or otherwise, does not necessarily constitute or imply lts endorsement, recommendation, or favoring by the United States Government or any agenisy thereof. The views and opinions of authors expressed herein do not necessarily state or reflect those of the United States Government or any agency thereof. 


\title{
COAL PRECURSORS FOR PRODUCTION OF CARBON AND GRAPHITE PRODUCTS
}

\author{
FINAL REPORT
}

April 8, 1996

Research Sponsored by the U.S. Department of Energy,

Office of Fossil Energy

Advanced Research and Technology Development Materials Program

Report Prepared by

I. C. Lewis, R. T. Lewis, and H. K. Mayer

UCAR CARBON COMPANY INC.

Parma Technical Center

P. O. Box 6116

Cleveland, Ohio 44101

under Subcontract 62X-SR928C, WBS Element-UCAR-3

for

OAK RIDGE NATIONAL LABORATORY

Oak Ridge, Tennessee 37831

Managed by

LOCKHEED MARTIN ENERGY RESEARCH CORPORATION

for the

U.S. DEPARTMENT OF ENERGY

under contract DE-AC05-96OR22464 
Chemical and analytical characterization data were obtained for NMP extracts of hydrotreated coal prepared by the West Virginia University (WVU) Group. Initial evaluation of small-scale samples produced by varying coal hydrotreating time, temperature, and catalyst type were used to define the conditions that would produce material suitable as binder, impregnant, $\mathrm{C} / \mathrm{C}$ matrix pitches and precursors for needle coke, anode coke, and mesophase pitch fibers. In addition to analytical characterization, mesophase formation studies were used to assess the coal extract quality.

Based on the small-scale testing, specific extracts derived from hydrotreating coal at $450^{\circ} \mathrm{C}$ were recommended for scaleup. Evaluation of the $450^{\circ} \mathrm{C}-2$-hour hydrotreated coal extract showed that it should be suitable as an impregnant or binder pitch and as a precursor for needle coke and mesophase pitch. This material formed a large-domained mesophase, despite a high oxygen and nitrogen content.

A small graphite artifact was produced using coke derived from the extract as the filler and the extract itself as the binder. The coefficient of thermal expansion (CTE) of $0.26 \times 10^{-6} / \mathrm{C}^{\circ}$, measured for the artifact is in the range found for electrode type graphite.

Coal extraction residues were steam activated to produce active carbons with surface areas from $400-700 \mathrm{~m}^{2} / \mathrm{gm}$. The program has demonstrated that the coal extraction process coupled with hydrotreatment, has the potential for providing a broad range of carbon and graphite products.

\section{INTRODUCTION}

The main goal of the overall program on "Coal-Based Precursors for Carbon Products" was to demonstrate the utility of coal extracts from the WVU extraction process as suitable base raw materials for the carbon products encompassed by the Carbon Products Consortium (CPC) team. These include binder and impregnating pitch, coke for graphite electrodes, cokes for anodes and specialty graphite, matrices for $\mathrm{C} / \mathrm{C}$ composites and raw material for mesophase pitch fibers. Each of these products has unique requirements for properties of a suitable precursor. Our previous work on the Coal Precursor for Graphite Program ${ }^{(1)}$ has shown that the WVU coal extraction process coupled with hydrotreatment, does have the potential for achieving this objective. Our current effort, therefore, involved the screening and evaluation of extracts produced by the WVU Group and recommending appropriate materials for scaleup for subsequent evaluation by Consortium Team members.

Our program involved an initial characterization of small-scale extracts using standard analytical methods and mesophase formation studies. This was followed by feedback to the WVU Group and to the CPC partners (Koppers, ALCOA, FMI, and APPI) with recommendation of material for scaleup. We also performed similar analytical and mesophase studies on some of the scaled-up extracts. 
As part of our program, we investigated the activation of the coal extraction residues for the purpose of producing a useful active carbon. A further task, which was started towards the end of the program, was to fabricate a small graphite artifact using coke derived from coal extract as the filler and the coal extract itself as a binder. The results of our studies are summarized in the following sections of this report.

\section{EXPERIMENTAL PROCEDURES}

A. Analytical Methods

1. Elemental Analysis - Elemental C, H, N, and O data were measured using a LECO CHN 1000 Analyzer. Elemental sulfur was measured using a LECO SC-132 carbon analyzer.

2. Thermogravimetric Analysis (TGA) - The data were obtained using TA Instruments 951 TGA module. Samples were heated at a rate of $10^{\circ} \mathrm{C} /$ minute in an inert atmosphere.

3. Nuclear Magnetic Resonance (NMR) - The NMR spectra were measured for $\mathrm{CS}_{2}$ solutions using a Varian A-60 spectrometer. In order to increase solubility, the solutions were prepared by either refluxing with solvent or by ultrasonic mixing.

4. Toluene and Trichlorobenzene (TCB) Solubility - The insoluble contents in toluene and TCB were determined using procedures in ASTM D-4072.

5. Mettler Softening Point (SP) - The softening points were measured using a Mettler FP83HT SP apparatus following the standard procedures in ASTM D-3104.

6. Modified Conradson Carbon (MCC) - The MCC data (carbon yields) were obtained using procedures in ASTM D-2146.

7. Gel Permeation Chromatography (GPC) - Molecular weight determinations were obtained from GPC measurements using a Dupont 850 Liquid Chromatographic System coupled with a Knauer High Temperature Differential Refractometer. The column configuration and calibration have been described elsewhere ${ }^{(2)}$. The GPC data were obtained for the portion soluble in TCB solvent at $90^{\circ} \mathrm{C}$. 
B. Mesophase Formation Studies

1. Test-Tube Evaluations

The small-scale extracts were evaluated initially for mesophase quality by heating $0.7-1.3 \mathrm{gm}$ samples in pyrex test tubes for six hours at $400^{\circ} \mathrm{C}$ in an inert gas environment. The objective was to produce a $15-40 \%$ mesophase content in the heat-treated residue, with most of the mesophase concentrated at the bottom of the test tube. After heat treatment, the pyrex test tubes were dissolved in aqueous HF, and the residues were mounted and polished by standard metallographic procedures to show a midline vertical cross-section. Polarized light microscopy techniques were used to make a qualitative assessment of the amount and quality of the mesophase and the presence, if any, of insoluble solid contaminants in the extracts.

2. Mesophase Domain Size

Specimens for automated image analysis were prepared by heat treating the coal extracts in an inert atmosphere at $400^{\circ} \mathrm{C}$ in ceramic boats and then preparing "annealed" samples for the mesophase domain size measurements using procedures described elsewhere ${ }^{(3)}$.

3. Hot-Stage Microscopy

Direct observations of the melting behavior, gas evolution characteristics, mesophase formation rate, and mesophase quality were made while heating the coal extracts up to $400^{\circ} \mathrm{C}$ at $6-10^{\circ} \mathrm{C} / \mathrm{min}$. and holding at $400^{\circ} \mathrm{C}$ for several hours. Details of the cover glass "sandwich" configuration used to contain the sample, the modified Kofler hot stage and the polarized light microscope have been reported previously ${ }^{(4)}$.

A simple CCD video camera and color monitor/VCR system were acquired late in the contract period to facilitate direct recording of the dynamic behavior of the coal extracts when they were heated on the hot-stage microscope.

\section{Steam Activations}

Activation experiments were carried out on powdered coal extraction residues using a specially designed tumbling furnace. The activations were performed by passing a mixture of steam and $\mathrm{N}_{2}$ over the sample maintained at a constant temperature of $900^{\circ} \mathrm{C}$. The treatment was interrupted intermittently and the sample weighed to determine percent burn-off. 


\section{Graphite Fabrication}

Small $19 \mathrm{~mm}$-diameter graphite electrodes were fabricated using calcined , produced from hydrotreated coal extract as filler and the hydrotreated extract as the binder. i binder and filler were mixed and extruded using standard procedures. The formed rods were the baked and graphitized to $3,000^{\circ} \mathrm{C}$.

\section{EXPERIMENTAL RESULTS}

A. Small-Scale Coal Extracts

\section{Sample Preparations}

The WVU Group initially carried out a series of small-scale extractions on a hydrotreated bituminous coal, WVGS-13421. The coal was hydrotreated at three different temperatures $350^{\circ} \mathrm{C}, 400^{\circ} \mathrm{C}$, and $450^{\circ} \mathrm{C}$ for a period of 1 hour in 800 psig $\mathrm{H}_{2}$. An additional set of hydrotreatments was carried out at $450^{\circ} \mathrm{C}$ for 2 hours. For each temperature, the hydrotreatments were performed using tetralin as a hydrogen donor without a catalyst, and with the use of a $\mathrm{Fe}_{2} \mathrm{~S}_{3}$ catalyst or a sulfided Mo catalyst. The NMP extractions were performed on the hydrotreated products.

Initial characterization data from the WVU Group showed that the softening temperatures of the $350^{\circ} \mathrm{C}$ and $400^{\circ} \mathrm{C}$ extracts were much too high to make them useful for most of the proposed applications of the Team. We therefore agreed to fully characterize only the $450^{\circ} \mathrm{C}$-treated materials.

Our characterization results for the extracts from the WVGS-13421 coal hydrotreated at $450^{\circ} \mathrm{C}$ for 1 and 2 hours follow.

\section{Analytical Characterization of $450^{\circ} \mathrm{C}-1$-Hour Samples}

The analytical characterization data for the 3 different materials prepared from hydrotreated coal at $450^{\circ} \mathrm{C}$ for 1 hour are presented in Table I. The Mettler softening points (measured at WVU) range from $156^{\circ}$ to $190^{\circ} \mathrm{C}$ which are too high for use as conventional binder and impregnant pitches. 
Table I

Characterization Data for Extracts from Hydrotreated Coal, WVGS-13421, $450^{\circ} \mathrm{C}-1$ Hour

\begin{tabular}{|l|c|c|c|}
\hline & $\begin{array}{c}\mathbf{C - 2 6 9 - 2} \\
\text { Thermal }\end{array}$ & $\begin{array}{c}\mathbf{C - 2 7 9 - 1} \\
\mathbf{F e}_{2} \mathbf{S}_{\mathbf{3}}\end{array}$ & $\begin{array}{c}\mathbf{C - 2 8 8 - 2} \\
\mathbf{M o}(\mathbf{S})\end{array}$ \\
\hline $\mathrm{SP}{ }^{\circ} \mathrm{C}$ & 190 & 156 & 158 \\
\hline$\% \mathrm{C}$ & 85.2 & 84.5 & 81.9 \\
\hline$\% \mathrm{H}$ & 5.51 & 5.63 & 5.82 \\
\hline $\mathrm{C} / \mathrm{H}$ atomic ratio & 1.30 & 1.26 & 1.18 \\
\hline$\% \mathrm{~N}$ & 3.08 & 2.89 & 3.73 \\
\hline$\% \mathrm{O}$ & 4.73 & 4.60 & 6.07 \\
\hline$\% \mathrm{~S}$ & 0.49 & 0.57 & 0.43 \\
\hline TGA Yd\% & 49 & 46 & 42 \\
\hline$\% \mathrm{TI}$ & 28.9 & $-\cdots--$ & ------ \\
\hline$\%$ Arom. H. & 38 & .36 & 33 \\
\hline GPC - MW (Mn) & 415 & 395 & 371 \\
\hline$\% \mathrm{TCB}$ Insoluble & 40.6 & 26.0 & 19.7 \\
\hline$\% \mathrm{NMP}$ & 0 & 0.1 & 5 \\
\hline
\end{tabular}

All the extracts show very high $\mathrm{N}$ and $\mathrm{O}$ contents. The Mo(S)-treated coal extract showed the highest $\mathrm{N}$ content as a result of retained NMP. The low $\mathrm{C} / \mathrm{H}$ ratios are expected for the hydrotreated extracts.

The proton NMR spectra obtained in $\mathrm{CS}_{2}$ solution are presented in Figures 1-3. The extracts were incompletely soluble in $\mathrm{CS}_{2}$. We were able to obtain essentially complete solution in pyridine D-5; however, the residual hydrogen or water in the solvent interfered with the analysis. The extracts all show extremely high aliphatic hydrogen contents resulting from the hydrogenation of aromatic rings. The NMR results are also summarized in Table I. For comparison, a spectrum for coal tar binder pitch exhibits about $85 \%$ aromatic hydrogen compared to the $33-38 \%$ range for the extracts. From the NMR data as well as the $\mathrm{C} / \mathrm{H}$ ratios, it appears that the catalytically treated materials may have been slightly more hydrogenated.

The TGA data for the 3 extracts are presented in Figures 4-6. The TGA carbon yields of $42-49 \%$ are quite acceptable for a pitch-type material. The low-temperature weight loss occurring from about $150-250^{\circ} \mathrm{C}$ is attributed to evolution of retained NMP solvent. This is particularly apparent in the TGA result for the Mo(S) product in Figure 6.

The GPC curves for the three $450^{\circ} \mathrm{C}-1-\mathrm{hr}$. samples are shown in Figures 7-9. They are all similar, except for a resolved doublet in the $\mathrm{Fe}_{2} \mathrm{~S}_{3}$ 
catalyzed material. They all show a broad symmetrical molecular weight distribution (MWD) with an apparent molecular weight range of about 250-900. The negative peaks in the GPC spectra are attributed to retained NMP. An estimate of the amount of NMP present was made by integrating these peaks and the results are summarized in the last line of Table I. Also shown in Table I are the toluene insolubles (TI) content and the measured insolubles in TCB.

\section{Analytical Characterization of $450^{\circ} \mathrm{C}-2$-Hour Samples}

The analytical data for the small-scale extracts obtained from coal hydrotreated at $450^{\circ} \mathrm{C}$ for 2 hours are summarized in Table II. The softening points are all considerably lower than those for the samples produced by hydrotreating for $450^{\circ} \mathrm{C}$ for 1 hour. Like the $450^{\circ} \mathrm{C}-1$-hour samples, the products in Table II exhibit very high $\mathrm{N}$ and $\mathrm{O}$ contents. The $\mathrm{H}$ contents, however, are higher, for the 2-hour samples reflecting the greater degree of hydrogenation. The 2-hour materials also showed a higher solubility in TCB than the 1-hour samples.

Table II

Characterization Data for Extracts from Hydrotreated Coal, WVGS-13421, $450^{\circ} \mathrm{C}-2$ Hours

\begin{tabular}{|l|c|c|c|}
\hline & $\begin{array}{c}\mathbf{C - 3 0 0 - 3} \\
\text { Thermal }\end{array}$ & $\begin{array}{c}\mathbf{C - 3 0 0 - 6} \\
\mathbf{F e}_{2} \mathbf{S}_{3}\end{array}$ & $\begin{array}{c}\mathbf{C - 3 0 0 - 9} \\
\mathbf{M o}(\mathbf{S})\end{array}$ \\
\hline $\mathrm{SP}{ }^{\circ} \mathrm{C}$ & 126 & 123 & 131 \\
\hline$\% \mathrm{C}$ & 84.2 & 83.9 & 86.1 \\
\hline$\% \mathrm{H}$ & 5.74 & 5.75 & 5.82 \\
\hline $\mathrm{C} / \mathrm{H}$ atomic ratio & 1.23 & 1.23 & 1.27 \\
\hline$\% \mathrm{~N}$ & 3.65 & 3.60 & 3.22 \\
\hline$\% \mathrm{O}$ & 5.53 & 5.66 & 4.61 \\
\hline$\% \mathrm{~S}$ & 0.35 & 0.42 & 0.41 \\
\hline TGA Yd\% & 40 & 41 & 42 \\
\hline$\%$ Arom. H & 40 & 40 & 43 \\
\hline GPC - Mn & 421 & 426 & 416 \\
\hline$\% \mathrm{TCB}$ Insoluble & 21.9 & 22.3 & 18.1 \\
\hline$\% \mathrm{NMP}$ & 2 & 2 & 1 \\
\hline
\end{tabular}

The proton NMR data for the extracts in Figures 10-12 show a lower content of long chain aliphatic protons than for the 1-hour treated samples, indicative of more selective hydrogenation of aromatic rings. The TGA results in Figures 13-15 demonstrate a reduced carbon yield for the 
$450^{\circ} \mathrm{C}$ - 2-hour materials as compared to the 1-hour samples. The presence of retained NMP is evident from the weight loss occurring below $300^{\circ} \mathrm{C}$. The GPC curves for the $450^{\circ} \mathrm{C}$ - 2-hour samples in Figures 16-18 exhibit somewhat broader MWD's when compared to the 1-hour extracts, which could account for the lower softening points. The amounts of NMP solvent present in the extracts, as measured from integrating the negative GPC peaks, are also summarized in Table II. From the measured properties, there appears to be no advantage for the use of a catalyst during the hydrotreatment.

\section{Mesophase Formation Studies of $450^{\circ} \mathrm{C}-1$-Hour and 2-Hour Samples}

Hot-stage microscopy examinations were carried out on all three of the small-scale $450^{\circ} \mathrm{C}-1$-hour samples. The primary results from the heat-up and hold period at $400^{\circ} \mathrm{C}$ are summarized in Table III. The initial softening temperatures from visual observations on the hot-stage were reasonably consistent with the Mettler S. P. results in Table I. The most unusual feature of the hot-stage microscopy observations was the onset of vigorous bubbling, presumably gas evolution, at temperatures in the $250^{\circ}$ to $275^{\circ} \mathrm{C}$ range. Conventional coal tar and petroleum pitches do not show this vigorous bubbling behavior below $300^{\circ} \mathrm{C}$. Evolution of residual NMP $\left(202^{\circ} \mathrm{C}\right.$ Boiling Point) could be responsible for a portion of the low-temperature gas evolution from the extracts, but certainly not all of it, because the vigorous gas evolution continued throughout the $300^{\circ}-400^{\circ} \mathrm{C}$ range. Dehydrogenation and/or decomposition reactions are suspected to be the origin of the gas evolution in these initial $450^{\circ} \mathrm{C}-1$-hour extracts, but an attempt to confirm evolution of $\mathrm{H}_{2}, \mathrm{H}_{2} \mathrm{O}$, or other low MW gases in this temperature range was not successful ${ }^{(5)}$.

Mesophase spheres were detected at the edge of the cover glass sandwich in all three $450^{\circ} \mathrm{C}-1$-hour samples after $\sim 20 \mathrm{~min}$. at $400^{\circ} \mathrm{C}$, indicating that all of them had comparable mesophase formation rates. The mesophase viscosity appeared to be reasonably low, based on bubble deformation behavior, and was essentially equivalent in the 3 samples. The overall mesophase quality was estimated to be borderline for a needle coke precursor.

All of the samples contained a small amount of finely divided solids, but none had a concentration judged high enough to have a significant effect on coke quality or performance as an impregnant. However, these finely divided solids would be expected to degrade the performance of these extracts as a mesophase pitch fiber precursor. 
All of the $450^{\circ} \mathrm{C}-1$-hour and $450^{\circ} \mathrm{C}-2$-hour samples were evaluated $\mathrm{b}$ the test-tube method. Measured yields after heat treatment at $400^{\circ} \mathrm{C}$ for six hours were in the 72 to $85 \%$ range. However, all of these samples foamed extensively during the heat treatment, so some material may have been lost. The extensive foaming during the test-tube heat treatments of the $450^{\circ} \mathrm{C}$ - 1-hour samples is consistent with the vigorous low-temperature bubbling behavior noted during the hot-stage microscopy observations. The $450^{\circ} \mathrm{C}$ - 2-hour samples foamed as much as the $450^{\circ} \mathrm{C}$ 1-hour samples in the test-tube heat treatments, so the additional reaction time at $450^{\circ} \mathrm{C}$ did not seem to have any significant effect on this characteristic of the small-scale extracts.

Examination of the domain size in the coalesced mesophase layer, which collects at the bottom of the test tube for conventional coal tar and petroleum pitches, can be used as an indicator of overall mesophase quality. Unfortunately, gas evolution from all of the small-scale extracts was so copious and disruptive that no well-defined coalesced mesophase formed at the bottom of the test tube. The actual appearance of all of the residues from test-tube heat treatments of the extracts is shown schematically in Figure 19. Because of the effects of gas evolution, we were not able to obtain a definitive evaluation of the uniformity and quality of the mesophase formed in the small-scale extract by the test-tube method. However, based on appearance, the overall mesophase quality was judged to be borderline for a needle coke precursor. The true mesophase quality may have been somewhat better, but the effects from the gas evolution precluded obtaining a definitive answer.

Finely divided solids were detected around the perimeter of most of the coalesced mesophase regions and many of the larger mesophase spheres in all of the test-tube residues. These solids provided a local, short-range decrease in the mesophase domain size, but the effect on the overall quality was minor.

Qualitative SEM/EDX analyses were carried out on the finely divided solids in the C-296-2 (Thermal, $450^{\circ} \mathrm{C}-1$-hour) extract. Most appeared to be carbonaceous, some contained high $\mathrm{Si}, \mathrm{Al}, \mathrm{O}$ levels $\left(\mathrm{SiO}_{2}+\mathrm{Al}_{2} \mathrm{O}_{3}\right.$ ?), and some contained high $\mathrm{Cu}, \mathrm{Fe}, \mathrm{S}$, and $\mathrm{O}$ levels (possibly a mixed copper and iron sulfate). The WVU Group suggested that the high $\mathrm{Cu}$ content in the last type of solid may have originated via attack of a copper gasket by the hot reactant mixture in the small-scale apparatus. 
Table III

Summary of Hot-Stage Microscopy Observations on $450^{\circ} \mathrm{C}$ - 1-Hour Samples

\begin{tabular}{|c|c|c|c|}
\hline SAMPLE & $\begin{array}{l}\text { INITIALL } \\
\text { SOFTENING } \\
\text { TEMP, }{ }^{\circ} \mathrm{C}\end{array}$ & $\begin{array}{c}\text { ONSET OF } \\
\text { VIGOROUS } \\
\text { BUBBLING, }{ }^{\circ} \mathrm{C}\end{array}$ & $\begin{array}{l}\text { INITIAL } \\
\text { DETECTION OF } \\
\text { MESOPHASE, } \\
\text { TIME AT } 400^{\circ} \mathrm{C}\end{array}$ \\
\hline $\begin{array}{l}\text { C269-2 } \\
\text { Thermal }\end{array}$ & 198 & $255-275$ & $21 \mathrm{~min}$. \\
\hline $\begin{array}{l}\mathrm{C} 279-1 \\
\mathrm{CF}-1, \mathrm{Fe}_{2} \mathrm{~S}_{3}\end{array}$ & 155 & 250 & 16 \\
\hline $\begin{array}{l}\mathrm{C} 288-2 \\
\mathrm{CF}-2, \mathrm{Mo}(\mathrm{S})\end{array}$ & 125 & 235 & 24 \\
\hline
\end{tabular}

B. Large-Scale Extracts from Hydrogenated Coal

1. Sample Preparation

Following our evaluation of the small-scale extracts, we recommended that the $450^{\circ} \mathrm{C}$ hydrotreated coal materials be scaled up for evaluation by the Team. The extracts produced without the use of any catalyst appeared suitable for testing as a binder and impregnating pitch and as a precursor for needle coke and mesophase pitch for fibers.

Scaleup of the hydrotreated coal extracts was performed at WVU by hydrotreating 600 grams of powdered coal in 1-gallon batch reactors. They investigated 2 different coals using hydrotreatment times of 1 and 2 hours at $450^{\circ} \mathrm{C}$. A description of the 4 materials produced (A066, A076, A075, and A073) and the properties measured at WVU are summarized in Table IV. The materials were also vacuum dried for an extended time in order to remove all of the retained NMP. We received about $\mathbf{2 0 0}$ gms of each material for further characterization. 
Table IV

Large-Scale, Hydrotreated Coal Extracts

\begin{tabular}{|c|c|c|c|c|}
\hline Prepared Conditions & $\begin{array}{c}\text { A066 } \\
\text { Coal } 13421 \\
450^{\circ} \mathrm{C}-1 \mathrm{hr} .\end{array}$ & $\begin{array}{c}\mathrm{A} 076 \\
\text { Coal } 13421 \\
450^{\circ} \mathrm{C}-2 \mathrm{hr}\end{array}$ & $\begin{array}{c}\mathrm{A075} \\
\text { Coal } 13423 \\
450^{\circ} \mathrm{C}-1 \mathrm{hr} .\end{array}$ & 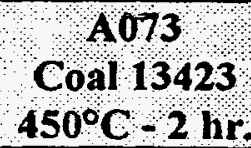 \\
\hline $\mathrm{SP},{ }^{\circ} \mathrm{C}$ & 155.8 & 101.7 & 129.3 & 112.5 \\
\hline Density, $g / c c$ & 1.264 & 1.227 & 1.220 & 1.223 \\
\hline $\mathrm{TI}, \mathrm{Wt} \%$ & 22.3 & 12.1 & 19.8 & 20.9 \\
\hline Coke Yield, Wt \% & 62.4 & 54.0 & 54.7 & 52.6 \\
\hline
\end{tabular}

\section{Analytical Data for Large-Scale $450^{\circ} \mathrm{C}$ Hydrotreated Coal Extracts}

The data and properties obtained for the four large-scale coal extracts are summarized in Table V. We fully characterized the more extensively hydrotreated (2-hour) samples because these had the lowest softening points, making them more suitable for use as binder or impregnating pitch. In general, these larger scale products were superior in behavior to the small-scale samples discussed previously. One major characteristic was the essentially complete absence of any retained NMP. The $\mathrm{N}$ and $\mathrm{O}$ contents were therefore substantially reduced, but they were still much higher than those found in conventional coal tar pitches. The $\mathrm{C} / \mathrm{H}$ ratios are similar to those in the comparably treated small-scale extracts.

Only the 2-hour products had softening points in the range of those for conventional carbon binder and impregnant pitches. The carbon yields of $52 \%$ for these materials are similar to those for commercial solids-free pitches of comparable softening point. 
Table $\mathrm{V}$

Properties of Large-Scale WVU Coal Extracts

\begin{tabular}{|c|c|c|c|c|}
\hline & $\begin{array}{c}\mathrm{A} 076 \\
450^{\circ} \mathrm{C}-2 \text { Hrs. } \\
\text { Coal } 13421\end{array}$ & $\begin{array}{r}\mathrm{A066} \\
450^{\circ} \mathrm{C}-1 \mathrm{Hr} \text {. } \\
\mathrm{Coal} 13421\end{array}$ & $\begin{array}{c}\text { A073 } \\
450^{\circ} \mathrm{C}-2 \text { Hrs. } \\
\text { Coal } 13423\end{array}$ & $\begin{array}{c}\mathrm{A} 075 \\
450^{\circ} \mathrm{C}-1 \mathrm{Hr} \text {. } \\
\mathrm{Coal} 13423\end{array}$ \\
\hline $\mathrm{SP},{ }^{\circ} \mathrm{C}$ & 104.7 & 160.7 & 115.3 & 134.5 \\
\hline MCC \% & 52.9 & 63.0 & 51.7 & 53.7 \\
\hline TGA Yd\% & 34 & 45 & 31 & 36 \\
\hline $\mathrm{C}, \%$ & 88.9 & $\cdots$ & 89.6 & $-\ldots$ \\
\hline $\mathrm{H}, \%$ & 5.85 & -ב-י- & 5.78 & $-\cdots$ \\
\hline C/H Ratio & 1.28 & $\ldots$ & 1.30 & $-\cdots$ \\
\hline $\mathrm{N}, \%$ & 2.20 & --.-- & 1.90 & $-\cdots$ \\
\hline $0, \%$ & 2.74 & 2.27 & 2.49 & 3.33 \\
\hline $\mathrm{S}, \%$ & 0.45 & - & 0.33 & $\ldots$ \\
\hline $\mathrm{ArH} \%$ & 45 & 44 & 48 & 39 \\
\hline $\mathrm{Mn}(\mathrm{GPC})$ & 367 & 417 & 389 & 388 \\
\hline Mesophase $(\mu)$ & 272 & 166 & 136 & 78 \\
\hline
\end{tabular}

The proton NMR spectra for the four materials in Table $\mathrm{V}$ are presented in Figures 20-23. All the extracts show substantial contents of hydrogenated ring systems. The decrease in the long chain aliphatic hydrogen peak at about $1.3 \mathrm{ppm}$, with extended hydrogenation, is particularly noticeable for the WVGS-13423 coal. The TGA curves for these large-scale extracts are shown in Figures 24-27. It is evident that the improved sample-drying procedure has removed any retained NMP. As expected, the total TGA weight losses increase for the more severely hydrotreated samples. The GPC curves for the four materials shown in Figures 28-31 do not exhibit any negative peaks due to NMP. The more severely hydrotreated coals show a broader molecular weight distribution (MWD) and the presence of an unresolved component at 280 a.m.u. when compared to the 1-hour samples.

3. Characterization of Extract Distillation Residues

We also received 3 distillation residues prepared by vacuum stripping of Sample A073 at temperatures of $250^{\circ} \mathrm{C}, 350^{\circ} \mathrm{C}$, and $400^{\circ} \mathrm{C}$. The materials are described in Table VI. The samples were prepared to determine whether we could detect any chemical changes resulting from heat treating at these temperatures. 
Table VI

Vacuum Distillation Residues from Sample A073 (WVGS $13423-450^{\circ} \mathrm{C}-2$ Hours)

\begin{tabular}{|c|c|c|}
\hline SAMPLE & DISTILLATION TEMP., $\%$ YTELD, \% \\
\hline D035-1 & 250 & 76 \\
\hline$D 035-2$ & 350 & 70 \\
\hline$D 035-3$ & 400 & 68 \\
\hline
\end{tabular}

We obtained NMR and TGA data for these residues and the results are summarized in Table VII. The NMR results show an increasing aromaticity with increasing depth of distillation. It is not possible to determine whether this effect is due to removal of volatile hydrogenated components during distillation or to low-temperature cracking reactions. The NMR data for the distillation residues are presented in Figures 32-34 while the TGA data are shown in Figures 35-37.

Table VII

Characterization of Hydrotreated Coal Extract Distillation Residues

\begin{tabular}{|c|c|c|c|}
\hline SAMPLE & $\%$ AROM H & \% LONG CHAN * & TGA Yd. \% \\
\hline D035-1 & 52 & 21 & 43 \\
\hline$D 035-2$ & 55 & 22 & 58 \\
\hline$D 035-3$ & 60 & 15 & 57 \\
\hline
\end{tabular}

* \% of aliphatic $\mathrm{H}$ that is long chain

\section{Mesophase Evaluations of Large-Scale Extracts}

Hot-stage microscopy examinations were carried out on both of the $450^{\circ} \mathrm{C}$ - 2-hour extracts in the same run. The A073 extract began to soften visibly at $94^{\circ} \mathrm{C}$, and the $\mathrm{A} 076$ extract had slumped noticeably by $104^{\circ} \mathrm{C}$ while they were being heated at $6^{\circ} \mathrm{C} / \mathrm{min}$. to $400^{\circ} \mathrm{C}$. The low initial visible softening temperatures on the hot-stage are consistent with the low Mettler S. P.'s given in Tables IV and V for these two extracts.

Both of these large-scale extracts evolved much less gas between $250^{\circ} \mathrm{C}-350^{\circ} \mathrm{C}$ as compared to the levels seen with all of the small-scale extracts. They behaved much more like conventional petroleum and coal tar pitches in their low-temperature gas evolution characteristics Apparently, the combined effects of more stringent drying conditions remove residual NMP and the somewhat more severe reaction conditj 
employed by the WVU Group for the large-scale extracts had nearly eliminated the severe gas evolution problem detected with the small-scale extracts.

Small amounts of mesophase spheres were detected at the edges of the cover glass sandwiches in both A073 and A076 extracts after $\sim 25$ min. at $400^{\circ} \mathrm{C}$, indicating that they had comparable initial mesophase formation rates. These onset times are only marginally longer than those noted for the $450^{\circ} \mathrm{C}$ - 1-hour, small-scale samples.

A hot-stage microscopy run carried out with both of the $450^{\circ} \mathrm{C}$ 1-hour samples showed an initial softening temperature of $114^{\circ} \mathrm{C}$ for A.066 extract and $146^{\circ} \mathrm{C}$ for $\mathrm{A} 075$ extract. These results are reasonably consistent with the Mettler S. P. data in Tables IV and V.

The A066 and A075 extracts also evolved much less gas in the $250^{\circ}-350^{\circ} \mathrm{C}$ range than the small-scale extracts. Clearly, the beneficial effects from the more stringent drying conditions and the somewhat different reaction conditions employed by the WVU Group were realized after only 1 hour at a nominal reaction temperature of $450^{\circ} \mathrm{C}$.

Small amounts of mesophase were detected at the perimeter of the cover glass sandwiches for both A066 and A075 extracts after 21-22 min. at $400^{\circ} \mathrm{C}$ on the hot-stage microscope. Hence, the mesophase formation rates of these large-scale $450^{\circ} \mathrm{C}$ - 1-hour samples were comparable to each other and to those for both the $450^{\circ} \mathrm{C}-1$ hour large-scale and small-scale extracts. Both of the $450^{\circ} \mathrm{C}-1$-hour samples appeared to generate slightly more true pyrolysis gas during the hold period at $400^{\circ} \mathrm{C}$ than the $450^{\circ} \mathrm{C}-$ 2-hour samples. This is an indication that the $450^{\circ} \mathrm{C}-1$-hour samples had a slightly higher initial rate for cracking reactions.

All of the large-scale extracts were heat treated in boats at $400^{\circ} \mathrm{C}$ to produce approximately $50 \%$ mesophase and then subjected to the "annealing" process for measurement of mesophase domain size. Polarized light (crossed polars) micrographs taken at $50 \mathrm{X}$ and $250 \mathrm{X}$ magnification of the derived mesophase are shown in Figures 38-41. It is apparent that the more extensively hydrotreated extracts give larger domain size mesophase than the less-treated 1-hour samples. It is also evident that the mesophase derived from the WVGS-13421 coal extract has a larger domain size than that from WVGS-13423 coal for the same hydrotreatment severity. The A076 extract from WVGS coal 13421 hydrotreated 2 hours at $450^{\circ} \mathrm{C}$ gave the largest mesophase domain size of any of the large-scale extracts. Mesophase domain sizes were obtained by image analysis and are reported in Table V. It is apparent that the domain sizes of the extracts from the 
WVGS-13423 coal are significantly smaller than the corresponding extract from the WVGS-13421 coal. The measured domain size of $272 \mu \mathrm{m}$ for the A076 extract is in the range found for excellent needle coke precursors.

The presence of solid particles in the coalesced mesophase and at the mesophase/isotropic phase boundary was noted to some extent in the annealed samples from all of the large-scale extracts. The WVGS-13421 extracts had more of this finely divided material than those derived from WVGS-13423. Figure 42 shows an area where the solids have collected or segregated in a small region near the edge of the coalesced mesophase from the A076 extract sample from WVGS-13421. SEM/EDX analyses of the particles in this cluster showed that several different materials were present. Carbonaceous particles with very high $\mathrm{C}$ and modest $\mathrm{S}$ levels were numerous, presumably coke-like material from the original coal which had not reacted during hydrotreatment. Particles with high $\mathrm{Si}, \mathrm{Al}$, and $\mathrm{O}$ contents were also prevalent, presumably very small ash particles from the original coal which had not been removed completely during the filtration step after hydrotreatment and NMP extraction. There was also a significant number of particles with high $\mathrm{Fe}, \mathrm{Cr}, \mathrm{S}$, and possibly $\mathrm{O}$ contents, presumably iron and chromium sulfates. A few particles with high $\mathrm{Ti}$ and $\mathrm{O}$ contents $\left(\mathrm{TiO}_{2}\right.$ ?) or high $\mathrm{Cu}, \mathrm{K}$, and small $\mathrm{O}$ contents (calcium and potassium sulfides or sulfates?) were also detected. As expected, most of these finely divided solids originate in the coal. Presumably, their removal would be more complete in larger scale equipment.

\section{Additional Extract Samples}

Small quantities of three additional extract materials were received from the WVU Group toward the end of the contract period. Two of the samples were the toluene soluble (TS) portions from hydrotreated coal extracts. D065-2 was the TS portion from a $450^{\circ} \mathrm{C}$ - 1 -hour hydrotreatment of the WVGS-13423 coal, and D054 was TS from a $450^{\circ} \mathrm{C}-2$-hour hydrotreatment of WVGS- 13421 coal. Both of these extracts melted in the $90^{\circ}-100^{\circ} \mathrm{C}$ range on the hot-stage microscope and had low yields after heating to $400^{\circ} \mathrm{C}$ at $6^{\circ} \mathrm{C} / \mathrm{min}$. Both were also very refractory during the hold period at $400^{\circ} \mathrm{C}$ and required $1.5-2.0$ hours to produce detectable mesophase spheres. An attempt to evaluate their mesophase domain size was unsuccessful because these TS materials were so unreactive under the normal heat treatment conditions and had low yields. The low softening point behavior and low yield upon heat treatment are consistent with the low MW range encompassed by toluene soluble material.

A third extract (A122) was prepared at WVU by carrying out a $450^{\circ} \mathrm{C}-1$-hour hydrotreatment on the toluene insoluble (TI) fraction from a large-scale NMP extract from an initial $450^{\circ} \mathrm{C}$ - 2-hour hydrotreatment of WVGS-13423 coal. This double-hydrotreated material had an initial softening temperature of $188^{\circ} \mathrm{C}$ and formed mesophase spheres quite rapidly at $400^{\circ} \mathrm{C}$, probably due to distillation of volatiles. Additional mesophase formed at a normal rate for 
thermal processing of good feedstocks at $400^{\circ} \mathrm{C}$. The mesophase quality appeared excellent on the hot stage. A standard mesophase evaluation showed that A122 had a domain size of approximately $200 \mu \mathrm{m}$ by visual observation on the annealed sample. Quantitative image analysis was not reliable on this sample because the mesophase in the annealed specimen had so many cracks. The oxygen content of the double-hydrotreated A122 material was still $1.88 \%$, indicating that the $O$ heteroatom structures in these coal extracts are very resistant to removal by hydrogenation. Even with this high oxygen content, the Al22 extract still formed a high-quality mesophase.

\section{Activation of Coal Extraction Residues}

The economics of the coal extraction process would be improved if the extraction residues also had some value. For this purpose, we attempted to activate these materials to produce a high surface area carbon. We obtained samples of the NMP extraction residue of raw coal WVGS-13421, as well as the extraction residue of a coal hydrotreated at $450^{\circ} \mathrm{C}$ for 2 hours (A-67).

Both materials were activated in a $\mathrm{H}_{2} \mathrm{O} / \mathrm{N}_{2}$ mixture at $900^{\circ} \mathrm{C}$ using a tumbling furnace. The hydrotreated (A-67) residue was very refractory and after about 81 hours of treatment gave a $64 \%$ burn-off. The raw coal residue was much more reactive and gave about $85 \%$ burn-off after 48 hours.

The surface areas and pore characteristics were determined for both materials at the Oak Ridge Laboratory by T. Burchell and E. L. Fuller. The measured surface area for the activated residue from the untreated coal was $770 \mathrm{~m}^{2} / \mathrm{gm}$ while that for the hydrotreated coal was $212 \mathrm{~m}^{2} / \mathrm{gm}$. The lower surface area and refractory nature of the hydrotreated residue is expected since it would have a greater ash content than the residue from the untreated coal. Since hydrotreatment increases the extraction yield, it would also lead to a higher ash content in the insoluble residue.

In a subsequent study, we obtained a second sample of the extraction residue from untreated coal and attempted to produce active carbons using different amounts of burn-off. We prepared 3 materials with active carbon yields of 50,65 , and $68 \%$. These samples were also submitted to T. Burchell for surface area measurement. The results are summarized in Table VIII along with our measured ash analysis for these activated carbons. The results show that surface area does increase with increasing burn-off. However, more detailed studies would be needed to determine the optimum activation that can be achieved for these residues. 
Table VIII

Active Carbons from Coal Extraction Residue (Activated at $900^{\circ} \mathrm{C}, \mathrm{H}_{2} \mathrm{O}$ )

\begin{tabular}{|c|c|c|c|}
\hline SAMPLE & ACTIVE CARBON Yd. \% & SURFACE AREA m $^{2} / \mathrm{gm}$ & $\%$ ASH \\
\hline $65-1$ & 50 & 464 & 4.6 \\
\hline $65-3$ & 65 & 410 & 4.3 \\
\hline $65-2$ & 68 & 332 & 4.2 \\
\hline
\end{tabular}

\section{E. Fabrication of Graphite Artifacts from Hydrotreated Coal Extracts}

We produced a graphite artifact using coal extract-derived coke as the filler and the coal extract itself as the binder. The coal extract coke was produced from WVGS-13421 coal hydrotreated for $450^{\circ} \mathrm{C}$ for 2 hours. The raw coke was prepared at WVU and then calcined to $1,100^{\circ} \mathrm{C}$ by $\mathrm{T}$. Burchell at the Oak Ridge Laboratory. The same coal NMP extract was used as the binder for graphite fabrication. The extract $(\mathrm{D}-085)$ had a $113^{\circ} \mathrm{C}$ Mettler softening point and a $52.6 \% \mathrm{MCC}$ value. After milling, the calcined coke was mixed with $1 / 3$ by weight of the coal extract binder and then extruded to produce $19 \mathrm{~mm}$-diameter rods. The rods were baked and graphitized to $3,000^{\circ} \mathrm{C}$. The properties measured for the graphitized rods were the following:

Coefficient of Thermal Expansion (CTE) $=0.26 \times 10^{-6} /{ }^{\circ} \mathrm{C}$

Specific Resistance $=9.55$ micro-ohm-meters

Density $=1.376 \mathrm{~g} / \mathrm{cc}$

The very low CTE value of 0.26 is similar to that measured for electrode graphite derived from petroleum needle coke. The relatively low density for the fabricated artifact could be due to an inappropriate binder level or to a puffing effect from the nitrogen in the coke.

\section{DISCUSSION}

Our screening evaluation studies have demonstrated that the coal extraction process has the potential for producing acceptable products for all the applications anticipated for the program. However, hydrotreatment is necessary to produce materials that are suitable for use as pitches, coke precursors, or mesophase raw materials.

The extract from the hydrotreated coal WVGS-13421, $450^{\circ}-2$ hours appears to be acceptable as either a carbon binder or impregnation pitch. Summarized in Table IX is a comparison of the properties for the A076 extract with those for commercial coal tar binder and petroleum impregnant pitches. The carbon yield (MCC) for the extract is quite high for a solids-free pitch with a softening point of $105^{\circ} \mathrm{C}$. Some of the analytical characteristics of the extract are quite unusual in comparison to those for the commercial pitches. The low aromatic 
hydrogen content reflects the effects of hydrotreatment of the precursor coal. The high $\mathrm{N}$ and $\mathrm{O}$ contents are also unusual for a binder or impregnant pitch material.

Our mesophase evaluation studies show that a material, such as the NMP extract of the WVGS-13421 coal hydrotreated for $450^{\circ} \mathrm{C}$ for 2 hours, is capable of forming a very large domain mesophase. This extract could therefore be used to produce a mesophase pitch which may be acceptable for fibers. The mesophase quality is comparable to that for precursors of needle coke. The high nitrogen content would be a drawback for processing of such a coke. The excellent mesophase development for a pitch such as the A076 extract is surprising because of its very high oxygen content. A high oxygen content in coal conversion materials has been previously associated with a high reactivity and a poor mesophase quality. Obviously, the form of oxygen in these hydrotreated coal extracts is different from that in typical coal conversion products and does not lead to a fast coking reactivity.

Our results have shown that a hydrotreated coal extract such as the A076 can be used directly as a binder pitch without any subsequent processing. The direct production of pitches by the extraction process could have advantages over the current commercial coal tar binder pitch processes which involve the distillation of coal tar. The need for coke oven processing for tar generation and the handling of by-products from tar distillation would be avoided. It is likely that pitches with different properties could be obtained by controlling the hydrotreatment and extraction conditions.

We have demonstrated that coke derived from hydrotreated coal extract can be used to produce graphite with a low coefficient of thermal expansion, a requisite for graphite electrodes. By altering the processing conditions and the use of blends, it would be possible to produce graphites with varying degrees of anistropy. We had shown previously that isotropic graphite can be produced from the coal extract ${ }^{(1)}$. No other process has the flexibility for producing this range of carbon materials. The high nitrogen contents of the extracts could, however, be a drawback for the use of these materials for some graphite products.

Finally, the extraction residue can be activated to produce an activated carbon. The best procedure for achieving an optimum active carbon still needs to be defined. However, the use of the residue for a commercial applications would definitely improve total process economics. 
Table XI

Properties of Coal Extract and Commercial Pitches

\begin{tabular}{|l|c|c|c|}
\hline & $\begin{array}{c}\text { EXTRACT } \\
\text { A076 }\end{array}$ & $\begin{array}{c}\text { COAL } \\
\text { BINDER }\end{array}$ & $\begin{array}{c}\text { PETROLEUM } \\
\text { MMPREGNANT }\end{array}$ \\
\hline SP, ${ }^{\circ} \mathrm{C}$ & 105 & 112 & 120 \\
\hline $\mathrm{MCC} \%$ & 53 & 58 & 52 \\
\hline $\mathrm{C}, \%$ & 88.9 & 93.8 & 91.5 \\
\hline $\mathrm{H}, \%$ & 5.85 & 3.92 & 5.0 \\
\hline $\mathrm{N}, \%$ & 2.20 & 0.70 & 0.6 \\
\hline $\mathrm{O}, \%$ & 2.74 & 0.93 & 0.5 \\
\hline $\mathrm{S}, \%$ & 0.45 & 0.56 & 2.5 \\
\hline ArH \% & 45 & 85 & 55 \\
\hline $\mathrm{Mol}$ Wt. & 370 & 410 & 500 \\
\hline
\end{tabular}


References:

(1) "Coal-Based Nuclear Graphites for the New Production Gas-Cooled Reactor" DOE Grant DE FG02-91 NP00159, Final Report, May 31, 1994

(2) R. A. Greinke and L. H. O'Connor, Anal. Chem. 52, 1877 (1980)

(3) R. T. Lewis, I. C. Lewis, R. A. Greinke, S. L. Strong, Carbon 25, 289 (1987)

(4) R. T. Lewis, Extended Abstract for $12^{\text {th }}$ Biennial Carbon Conference, Pittsburgh, PA, p. 215,1975

(5) E. L. Fuller, ORNL, personal communication

\section{Figures}

Figure 1: $\quad$ Proton NMR in $\mathrm{CS}_{2}$ Solution for C-269-2, Hydrotreated Coal $450^{\circ} \mathrm{C}-1 \mathrm{Hour}$, No Catalyst

Figure 2: $\quad$ Proton NMR in $\mathrm{CS}_{2}$ Solution for C-279-1, Hydrotreated Coal $450^{\circ} \mathrm{C}-1$ Hour, $\mathrm{Fe}_{2} \mathrm{~S}_{3}$ Catalyst

Figure 3: $\quad$ Proton NMR in $\mathrm{CS}_{2}$ Solution for C-288-2, Hydrotreated Coal $450^{\circ} \mathrm{C}-1 \mathrm{Hour}$, $\mathrm{Mo}(\mathrm{S})$ Catalyst

Figure 4: $\quad$ TGA Curve for C-269-2, Hydrotreated Coal $450^{\circ} \mathrm{C}-1$ Hour, No Catalyst

Figure 5: $\quad$ TGA Curve for C-279-1, Hydrotreated Coal $450^{\circ} \mathrm{C}-1 \mathrm{Hour}, \mathrm{Fe}_{2} \mathrm{~S}_{3}$ Catalyst

Figure 6: $\quad$ TGA Curve for C-288-2, Hydrotreated Coal $450^{\circ} \mathrm{C}-1$ Hour, $\mathrm{Mo}(\mathrm{S})$ Catalyst

Figure 7: Gel Permeation Chromatography (GPC) Curve for C-269-2, Hydrotreated Coal $450^{\circ} \mathrm{C}$ - 1 Hour, No Catalyst

Figure 8: Gel Permeation Chromatography (GPC) Curve for C-279-1, Hydrotreated Coal $450^{\circ} \mathrm{C}-1 \mathrm{Hour}, \mathrm{Fe}_{2} \mathrm{~S}_{3}$ Catalyst

Figure 9: Gel Permeation Chromatography (GPC) Curve for C-288-2, Hydrotreated Coal $450^{\circ} \mathrm{C}-1$ Hour, $\mathrm{Mo}(\mathrm{S})$ Catalyst

Figure 10: Proton NMR in $\mathrm{CS}_{2}$ for C-300-3, Hydrotreated Coal $450^{\circ} \mathrm{C}-2$ Hours, No Catalyst 
Figure 11: Proton NMR in $\mathrm{CS}_{2}$ for C-300-6, Hydrotreated Coal $450^{\circ} \mathrm{C}-2$ Hours, $\mathrm{Fe}_{2} \mathrm{~S}_{3}$ Catalyst

Figure 12: Proton NMR in $\mathrm{CS}_{2}$ for C-300-9, Hydrotreated Coal $450^{\circ} \mathrm{C}-2$ Hours, $\mathrm{Mo}(\mathrm{S})$ Catalyst

Figure 13: TGA Curve for C-300-3, Hydrotreated Coal $450^{\circ} \mathrm{C}-2$ Hours, No Catalyst

Figure 14: TGA Curve for C-300-6, Hydrotreated Coal $450^{\circ} \mathrm{C}-2$ Hours, $\mathrm{Fe}_{2} \mathrm{~S}_{3}$ Catalyst

Figure 15: TGA Curve for C-300-9, Hydrotreated Coal $450^{\circ} \mathrm{C}-2$ Hours, $\mathrm{Mo}(\mathrm{S})$ Catalyst

Figure 16: Gel Permeation Chromatography Curve for C-300-3, Hydrotreated Coal $450^{\circ} \mathrm{C}-2$ Hours, No Catalyst

Figure 17: Gel Permeation Chromatography Curve for C-300-6, Hydrotreated Coal $450^{\circ} \mathrm{C}-2$ Hours, $\mathrm{Fe}_{2} \mathrm{~S}_{3}$ Catalyst

Figure 18: Gel Permeation Chromatography Curve for C-300-9, Hydrotreated Coal $450^{\circ} \mathrm{C}-2$ Hours, $\mathrm{Mo}(\mathrm{S})$ Catalyst

Figure 19: Schematic Diagram of Test-Tube Heated Coal Extract

Figure 20: Proton NMR Spectrum for A076 from Hydrotreated Coal WVGS-13421 $-450^{\circ} \mathrm{C}, 2$ Hours

Figure 21: Proton NMR Spectrum for A066 from Hydrotreated Coal WVGS-13421 $-450^{\circ} \mathrm{C}, 1$ Hour

Figure 22: Proton NMR Spectrum for A073 from Hydrotreated Coal WVGS- $13423-450^{\circ} \mathrm{C}, 2$ Hours

Figure 23: Proton NMR Spectrum for A075 from Hydrotreated Coal WVGS- $13423-450^{\circ} \mathrm{C}, 1$ Hour

Figure 24: TGA Curve for A076 from Hydrotreated Coal WVGS- $13421-450^{\circ} \mathrm{C}, 2$ Hours

Figure 25: TGA Curve for A066 from Hydrotreated Coal WVGS-13421 $-450^{\circ} \mathrm{C}, 1$ Hour

Figure 26: TGA Curve for A073 from Hydrotreated Coal WVGS- $13423-450^{\circ} \mathrm{C}, 2$ Hours

Figure 27: TGA Curve for A075 from Hydrotreated Coal WVGS- $13423-450^{\circ} \mathrm{C}, 1$ Hour

Figure 28: Gel Permeation Chromatogram for A076 from Hydrotreated Coal WVGS-13421 - $450^{\circ} \mathrm{C}, 2$ Hours 
Figure 29: Gel Permeation Chromatogram for A066 from Hydrotreated Coal WVGS-13421 $-450^{\circ} \mathrm{C}, 1$ Hour

Figure 30: Gel Permeation Chromatogram for A073 from Hydrotreated Coal WVGS- $13423-450^{\circ} \mathrm{C}, 2$ Hours

Figure 31: Gel Permeation Chromatogram for A075 from Hydrotreated Coal WVGS- $13423-450^{\circ} \mathrm{C}, 1$ Hour

Figure 32: Proton NMR Spectrum for $250^{\circ} \mathrm{C}$ Distillation Residue D035-1

Figure 33: Proton NMR Spectrum for $350^{\circ} \mathrm{C}$ Distillation Residue D035-2

Figure 34: Proton NMR Spectrum for $400^{\circ} \mathrm{C}$ Distillation Residue D035-3

Figure 35: TGA Curve for $250^{\circ} \mathrm{C}$ Distillation Residue D035-1

Figure 36: TGA Curve for $350^{\circ} \mathrm{C}$ Distillation Residue D035-2

Figure 37: TGA Curve for $400^{\circ} \mathrm{C}$ Distillation Residue D035-3

Figure 38: Annealed Mesophase Pitch from Sample A076

Figure 39: Annealed Mesophase Pitch from Sample A066

Figure 40: Annealed Mesophase Pitch from Sample A073

Figure 41: Annealed Mesophase Pitch from Sample A075

Figure 42: $\quad$ Area in Annealed Mesophase Pitch from Sample A076 Showing Clusters of Solid Particles 


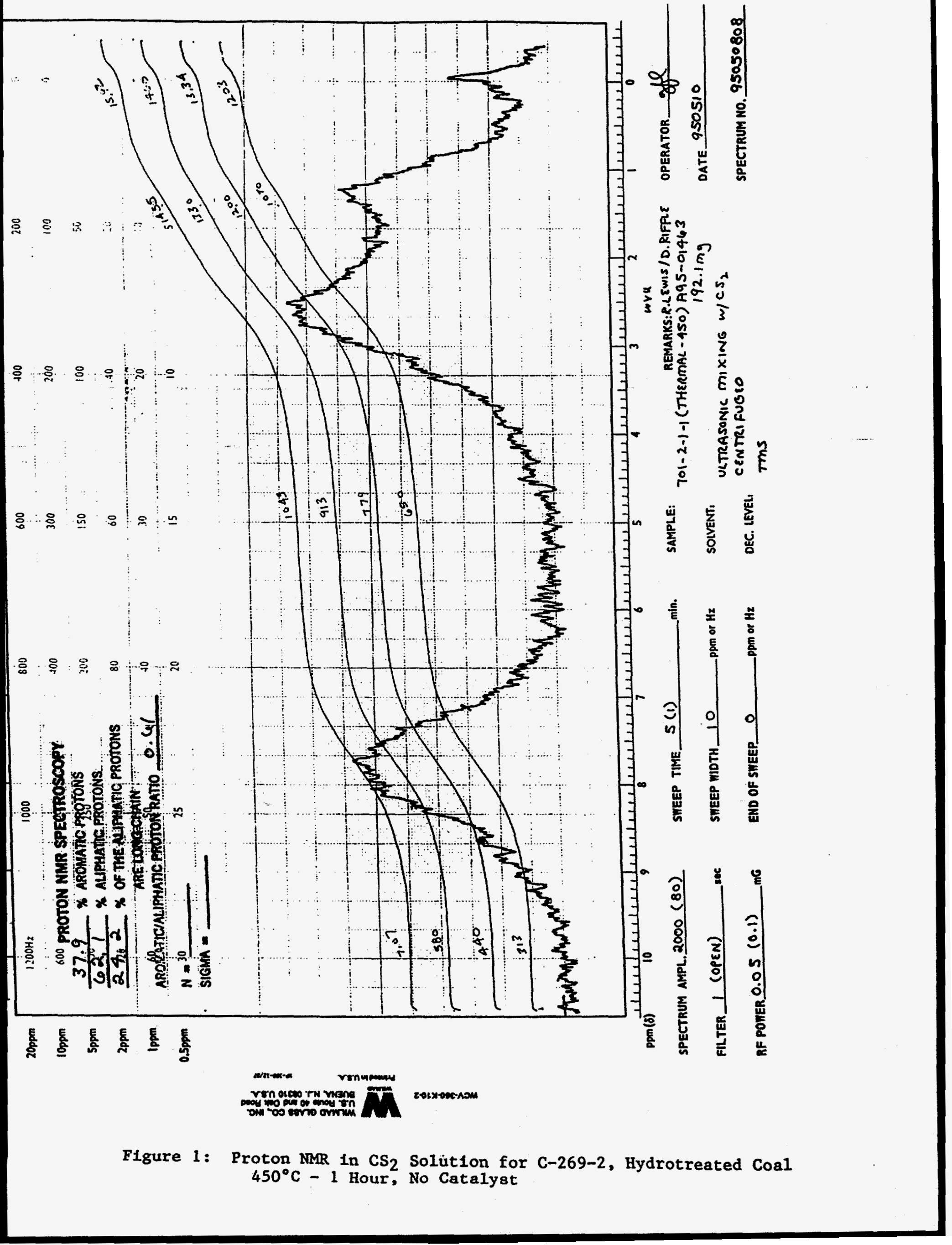




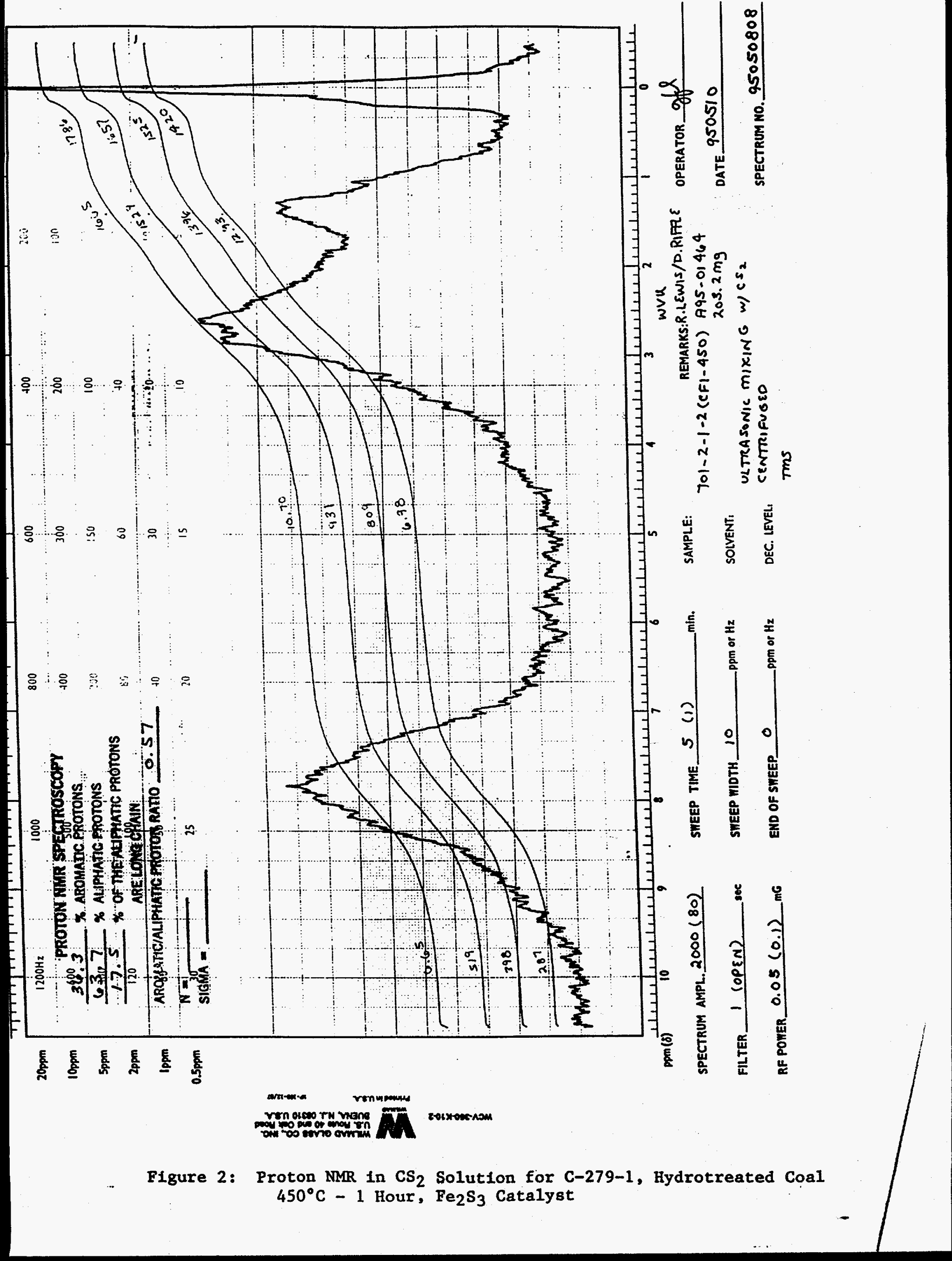




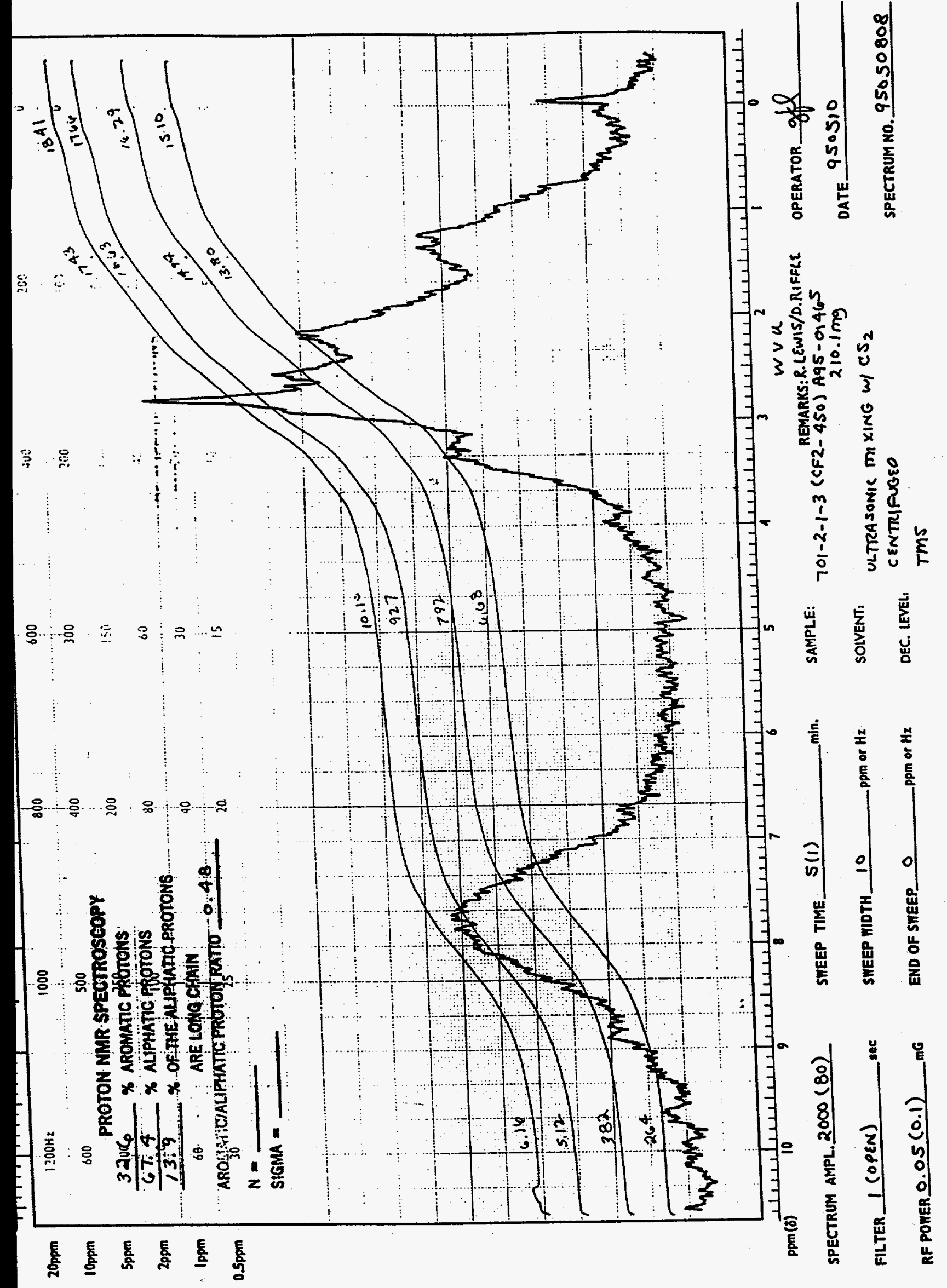

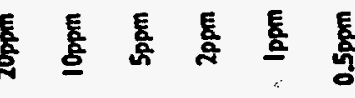

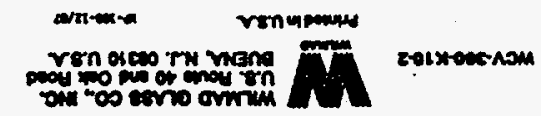

Figure 3: Proton NMR in $\mathrm{CS}_{2}$ Solution for C-288-2, Hydrotreated Coal $450^{\circ} \mathrm{C}$ - 1 Hour, Mo(S) Catalyst 


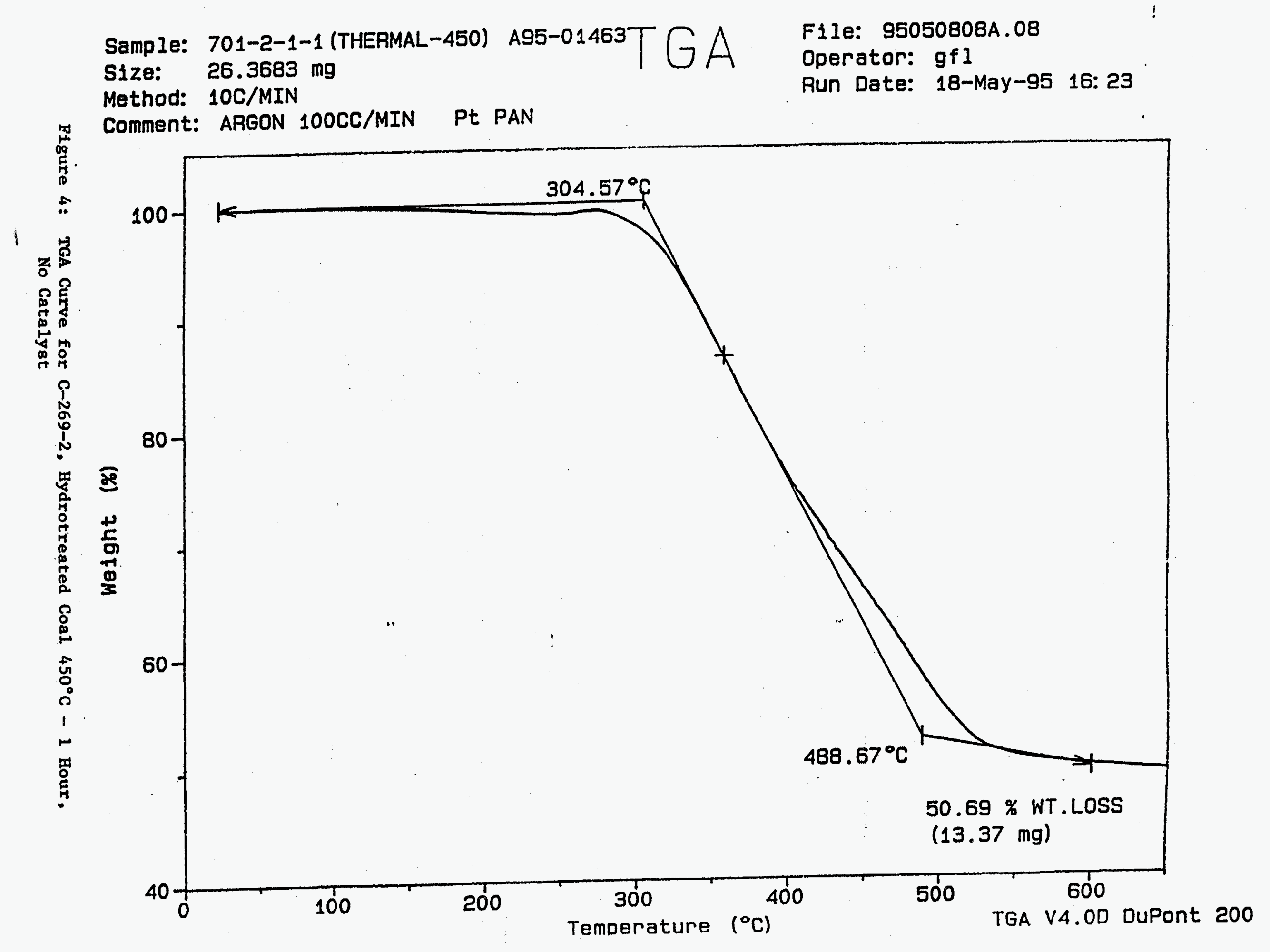




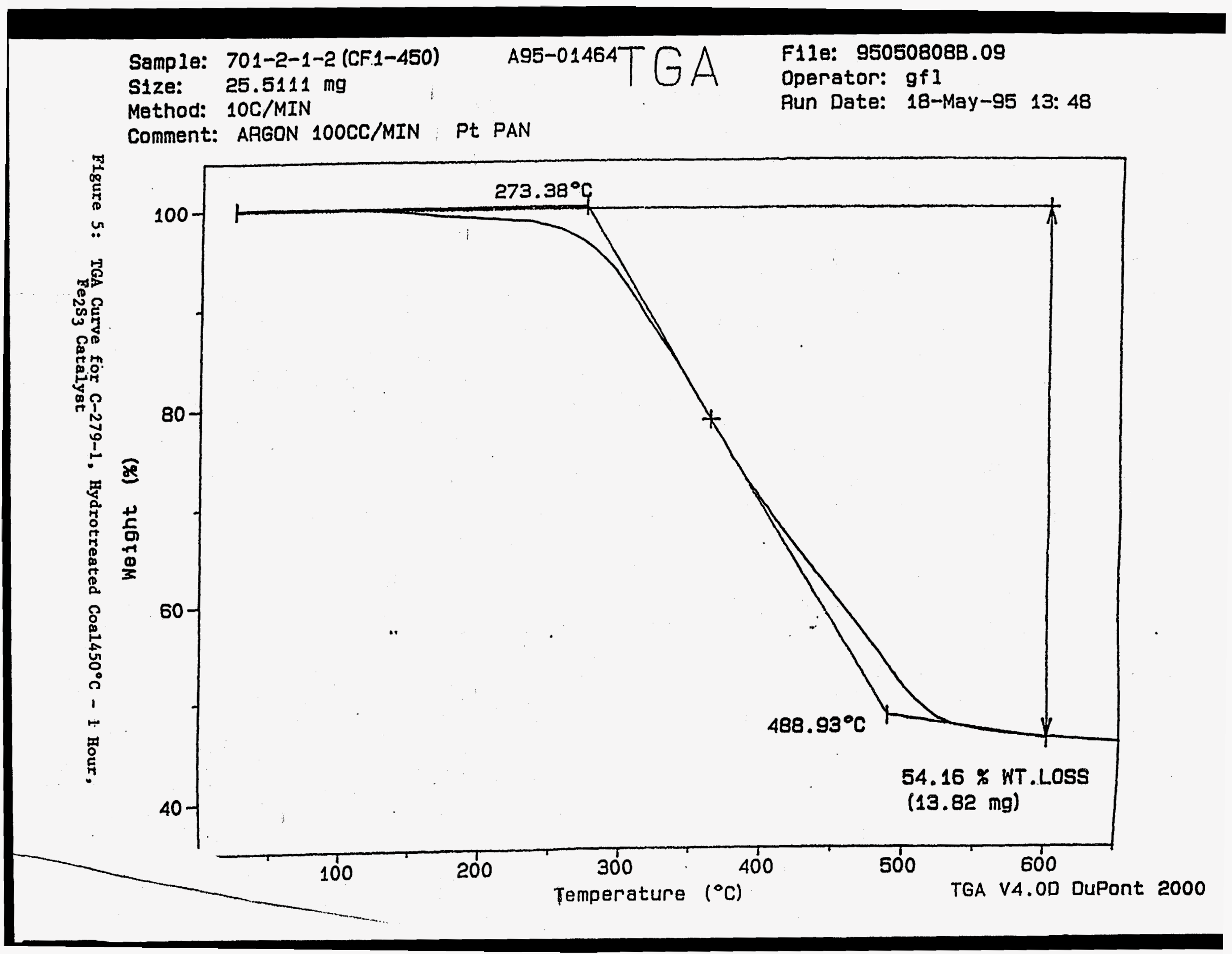




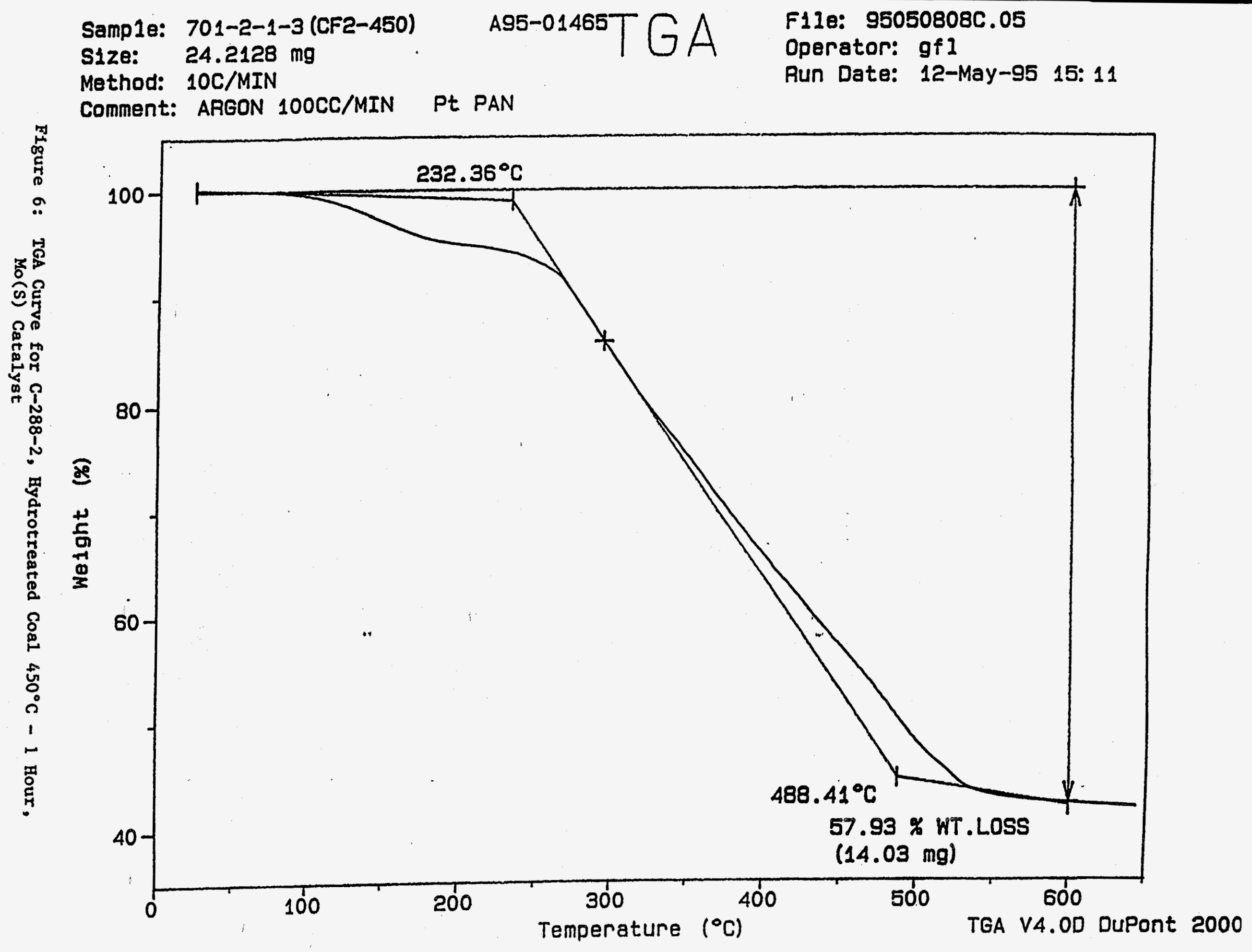


project Name: GPC Sample Name:

$701-2-1-1$.

Vial:

Injection:

pate Acquired: Brocessing Method:

commentis: .. .

$$
2
$$$$
1
$$

GPC
06/22/95 01:55:58 - PM

95050808-1:1g3ml TCB Thermal - 450. prepped. 5/16/95
Sauple Type:

Volume:

Run Time:

Date Processed:

Pressure:

Submitter:
Broad Unknown

100.00

$30.0 \mathrm{~min}$

06/23/95 10:02:42 AM 75

hkm

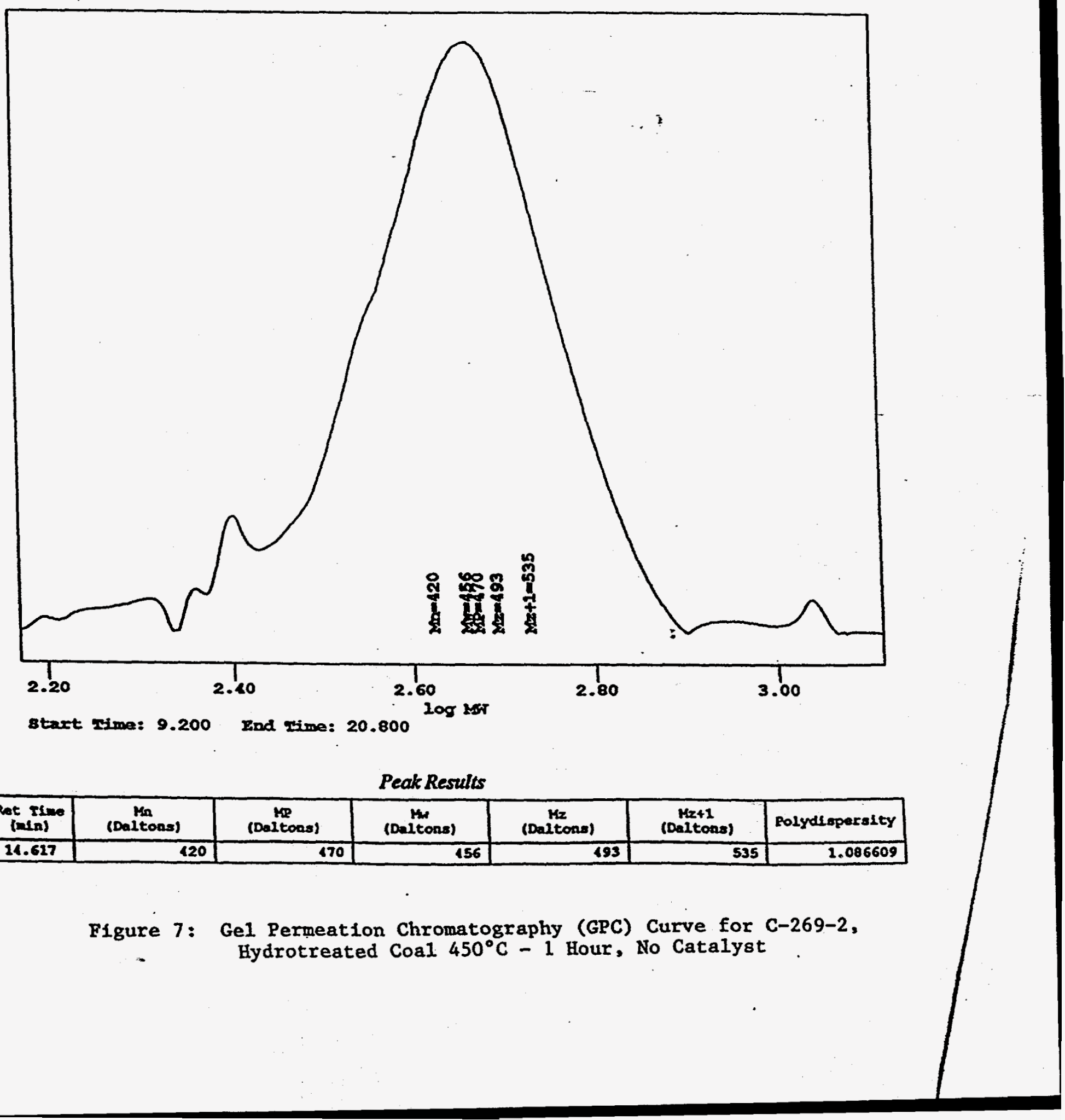


Broject Name: GPC

Sample Name: 701-2-1-2,

Vial:

Injection:

Date Acquired:

Processing Method:

Comments:

3

1

GPC
$06 / 22 / 95 \cdot 02: 51: 24$ BNF

95050808 .1g3m ICB CF-1- 450 prepped 5/16/95

$\begin{array}{ll}\text { Sample Type: } & \text { Broad Unknown } \\ \text { Volume: } & 100.00 \\ \text { Run Time: } & 30.0 \text { min } \\ \text { Date Processed: } & 06 / 23 / 95 \quad \text { 10:02:13 AM } \\ \text { Pressure: } & 75 \\ \text { Submitter: } & \text { hkm }\end{array}$

Sarple Type: Broad Unknown

06/23/95 10:02:13 AM

hikm

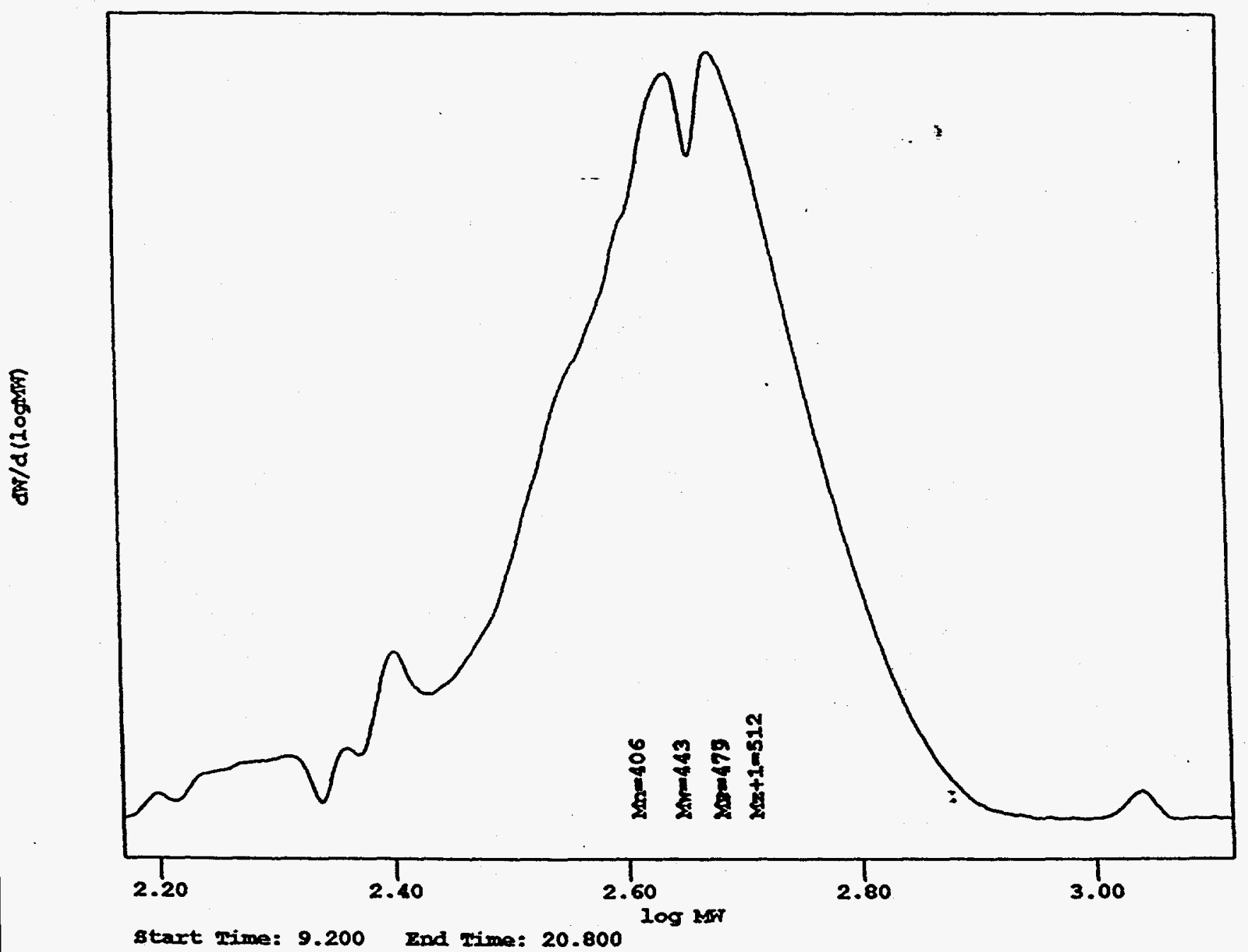

Peak Results

\begin{tabular}{|c|c|c|c|c|c|c|c|}
\hline 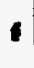 & $\begin{array}{l}\text { Ret Ine } \\
\text { (min) }\end{array}$ & $\operatorname{Mn}_{\text {(Daitons) }}$ & $\underset{\text { (Dsitons) }}{\text { MP }}$ & (Daltons) & $\begin{array}{c}\text { Mz } \\
\text { (Daitons) }\end{array}$ & $\begin{array}{c}\mathrm{Mz+1} \\
\text { (Daltons) }\end{array}$ & Polyds spersity \\
\hline 1 & 14.517 & 106 & 479 & 413 & 477 & 512 & 1.090000 \\
\hline
\end{tabular}

Figure 8: Gel Permeation Chromatography (GPC) Curve for C-279-1, Hydrotreated Coal $450^{\circ} \mathrm{C}-1$ Hour, $\mathrm{Fe}_{2} \mathrm{~S}_{3}$ Catalyst 
3roject Name: Sample Name:

vial:

infection:

bate Acquired: Processing Method:

comments:

\section{GPC}

701-2-1-3 :

4

1

06/22/95 03:32:41 EM.

GPC
Sample Type:

Volume:

Run Time:

Date Processed:

Rressure:

Submitter:

95050808 .1g3mil TCB CE-2- 450 prepped 5/16/95"
Broad Unknown

100.00

30.0 min

06/23/95 10:01:31 AM 75

hkm

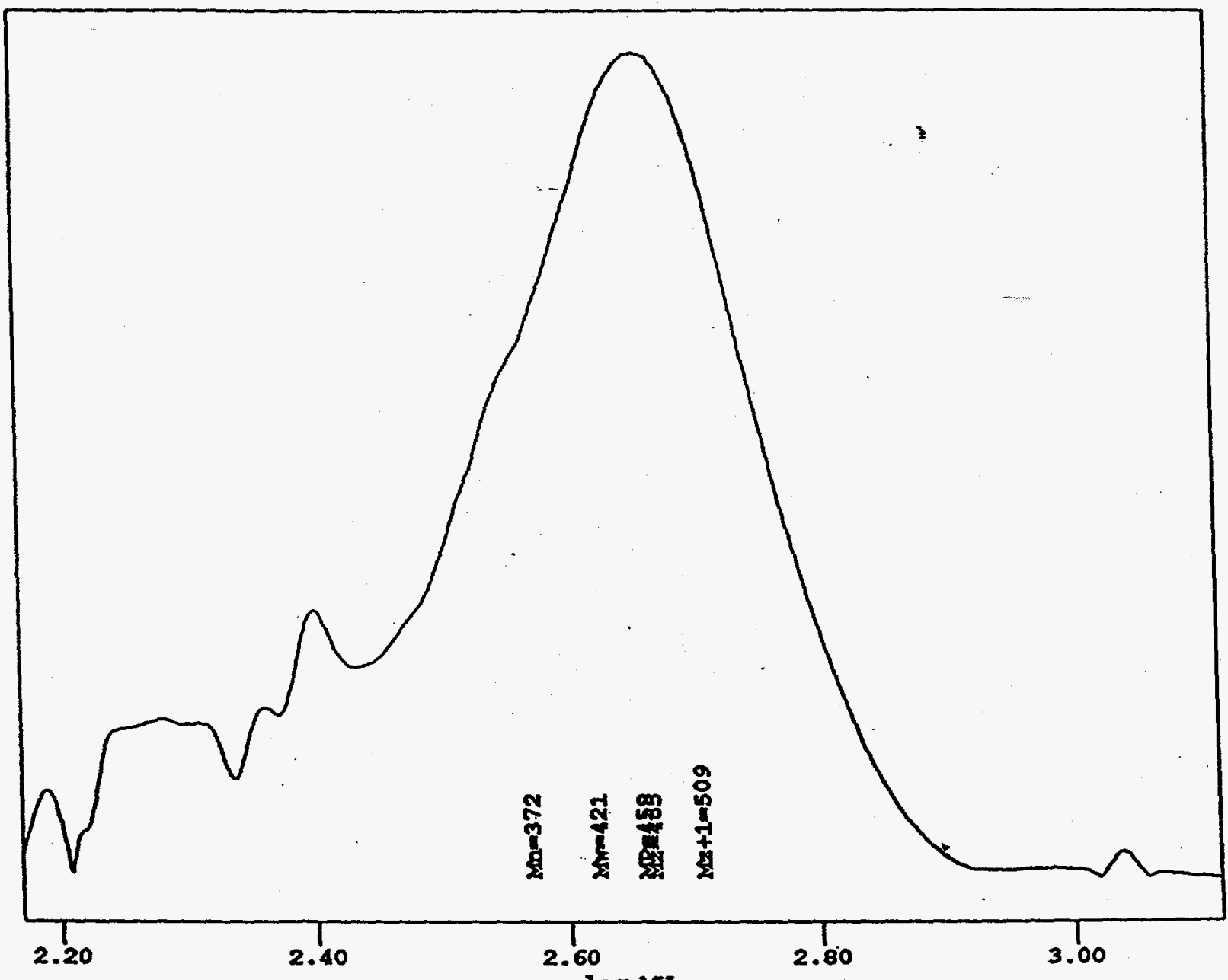

Start Fime: 9.200 End Time: 20.800

$\log$

Peak Results

\begin{tabular}{|c|c|c|c|c|c|c|c|}
\hline 11 & $\begin{array}{c}\text { Ret Tine } \\
\text { (nin) }\end{array}$ & $\mathrm{Mn}_{\text {(Daltons) }}$ & $\begin{array}{c}\text { MP } \\
\text { (Daitona) }\end{array}$ & (Daitons) & $\begin{array}{c}\text { Mr } \\
\text { (Daitons) }\end{array}$ & $\begin{array}{c}\text { Hex+1 } \\
\text { (Daltons) }\end{array}$ & Polydlepersity \\
\hline 1 & 14.750 & 372 & 458 & 121 & 465 & 509 & 2.129627 \\
\hline
\end{tabular}

Figure 9: Gel Permeation Chromatography (GPC) Curve for C-288-2, Hydrotreated Coal $450^{\circ} \mathrm{C}-1$ Hour, Mo(s) Catalyst 


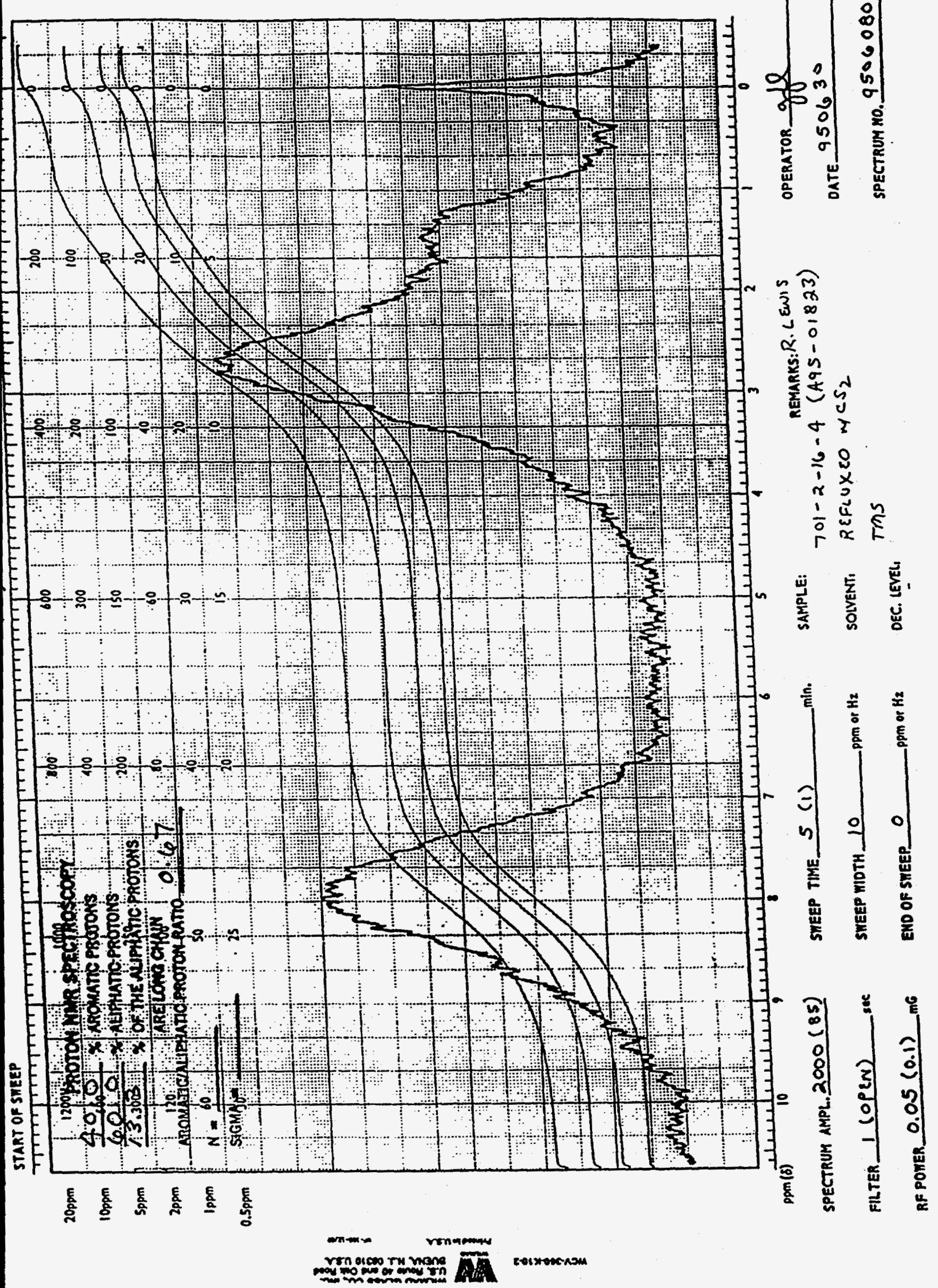

Figure 10: Proton NMR in $\mathrm{CS}_{2}$ for C $-300-3$, Hydrotreated Coal $450^{\circ} \mathrm{C}-2$ Hours, No Catalyst 


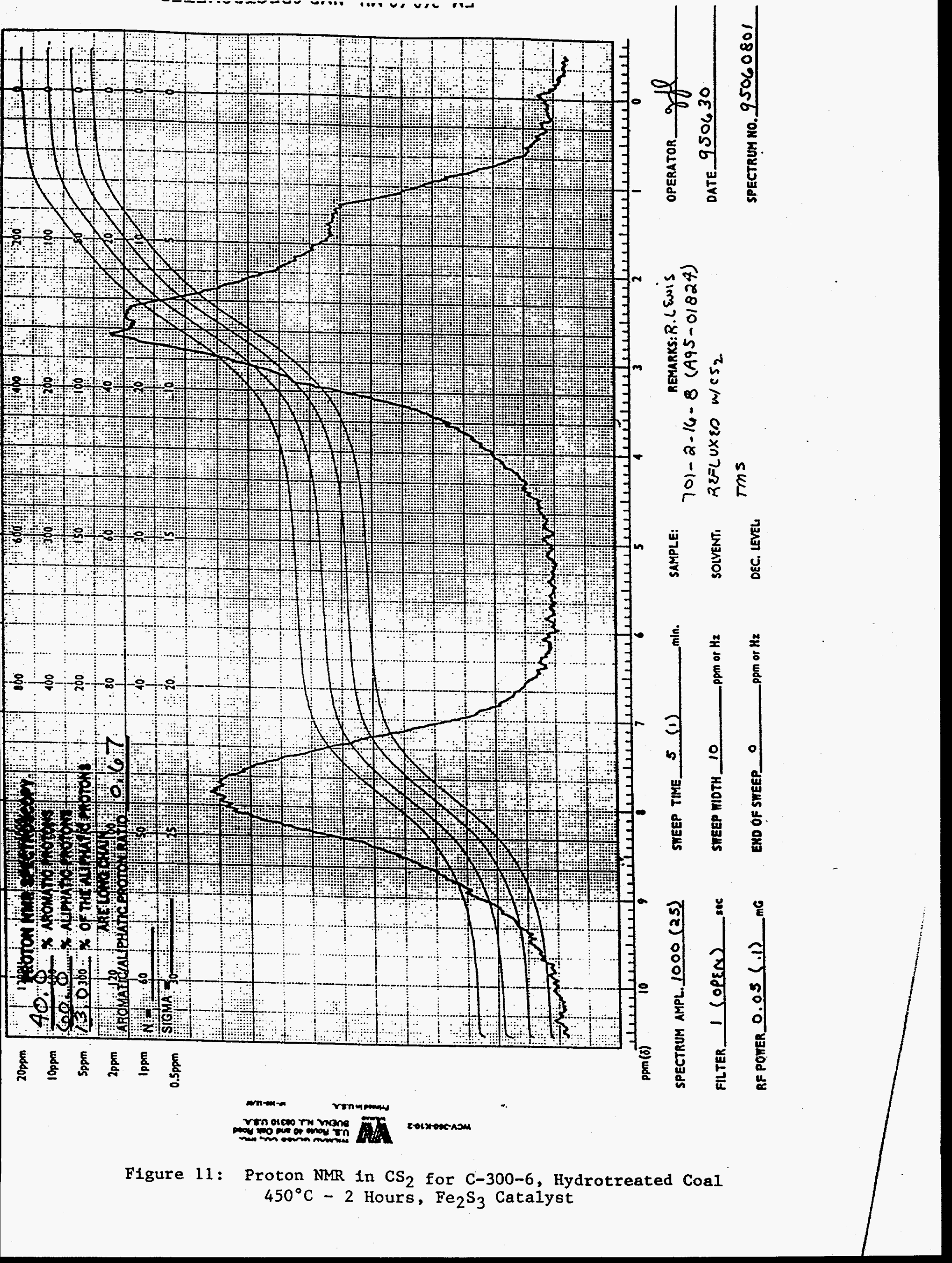



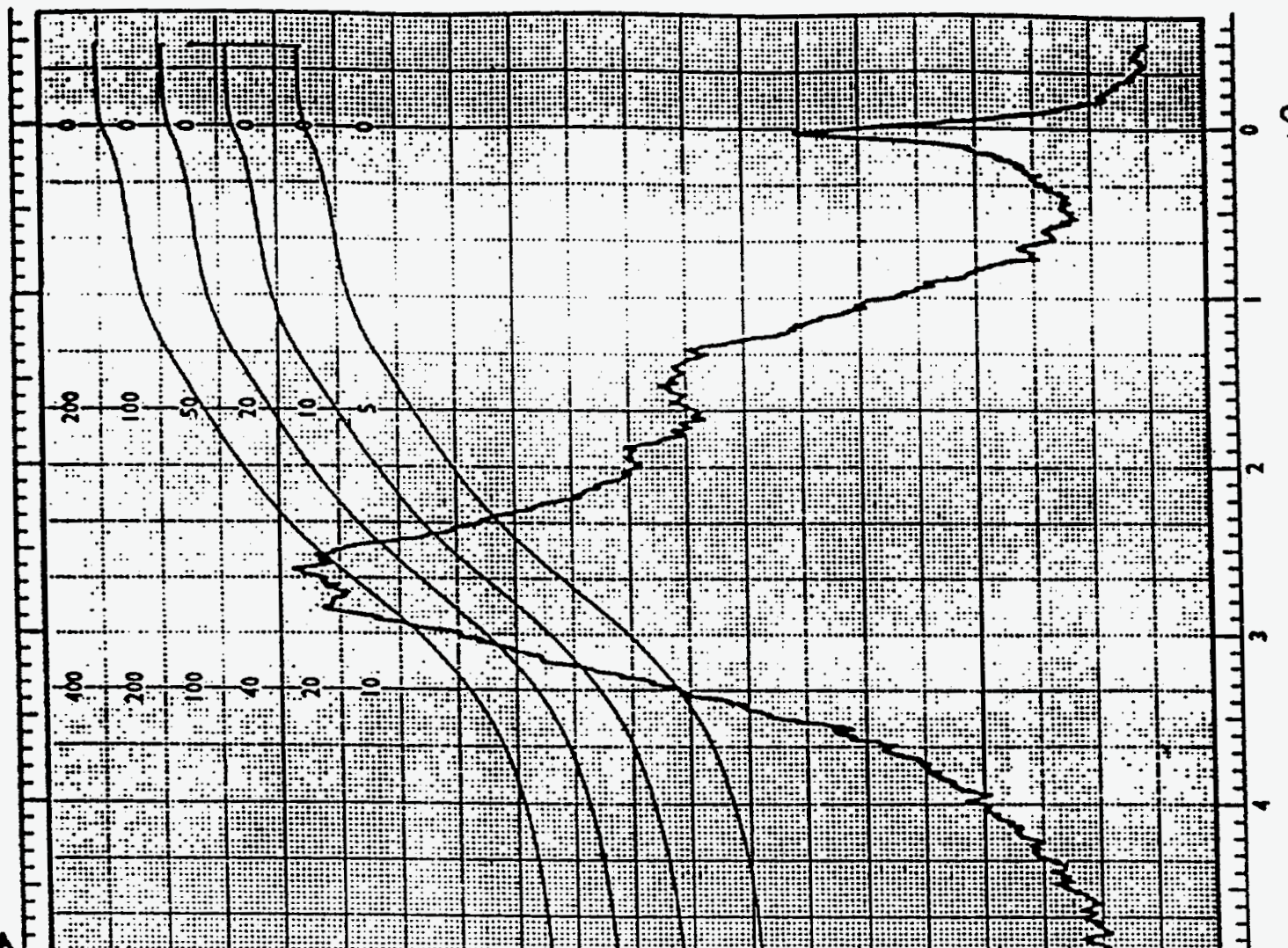

$\hat{\bar{f}}$

王

$8+1000 \%$

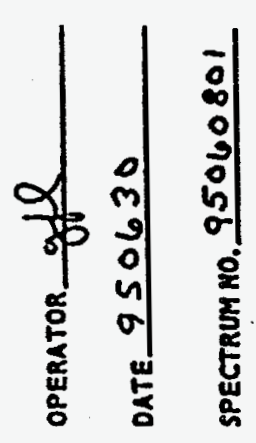

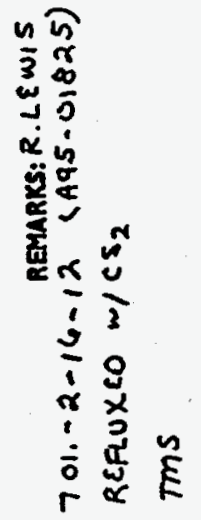

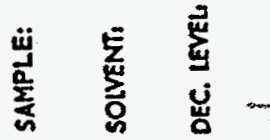

$\stackrel{\dot{E}}{E} \cong$

言

8:

EF

产 总

至

ô

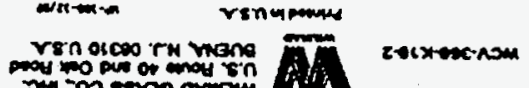

Figure 12: Proton NMR in $\mathrm{CS}_{2}$ for $\mathrm{C}-300-9$, Hydrotreated Coal $450^{\circ} \mathrm{C}-2$ Hours, Mo(S) Catalyst 


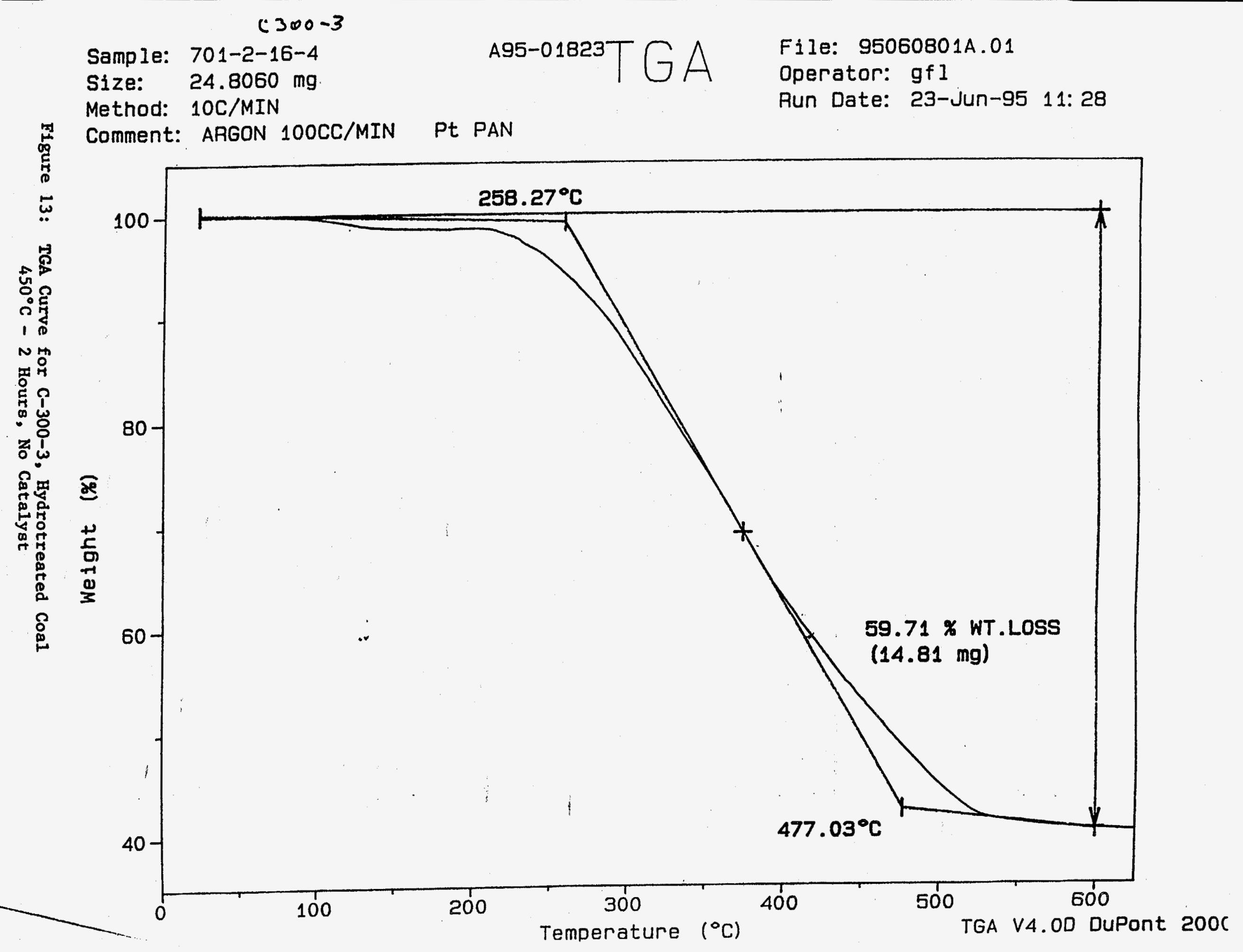




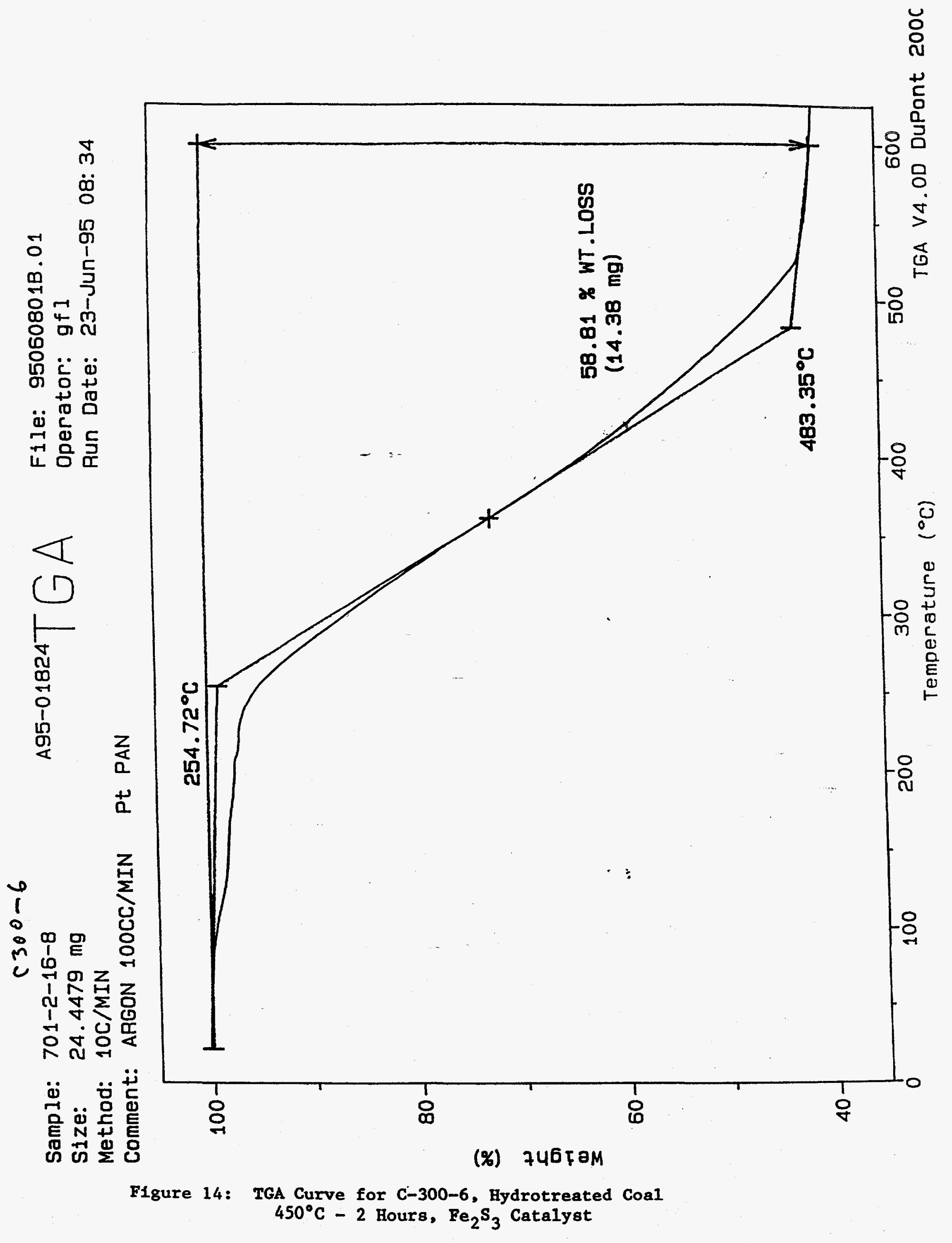


roject rame:

ample Name:

rial:

injection:

ate Acquired:

rocessing Method:

omments:

$\begin{array}{lll}\text { GPC } & \text { Sample Tyge: } & \text { Broad Unknown } \\ 701-2-16-4 & \text { Volume: } & 100.00 \\ 2 & \text { Run Time: } & 30.0 \text { min } \\ 1 & \text { Date Processed: } & 06 / 19 / 9509: 38: 03 \mathrm{AM} \\ 06 / 16 / 9512: 43: 30 \mathrm{BM} & \text { Pressure: } & 75 \\ \text { GPC } & \text { Submitter: } & \text { RTL }\end{array}$

C300-3, Thermal 450-2 prepped 6/15/95 .25g/7ml TCB no fl. rt. mkr. 95060801

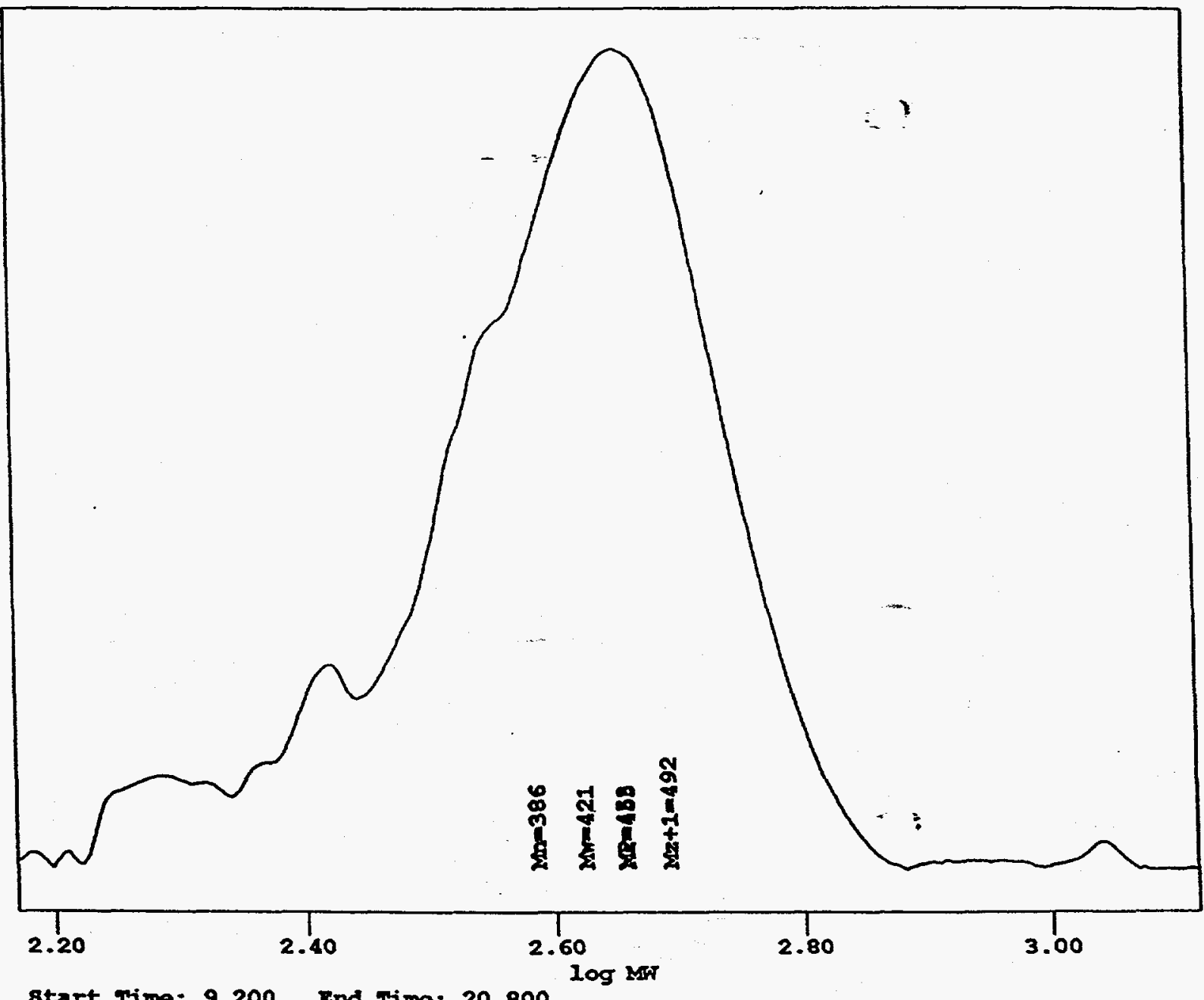

start rime: 9.200 End rime: 20.800

Peak Results

\begin{tabular}{|c|c|c|r|r|r|r|r|}
\hline & $\begin{array}{c}\text { Ret Iime } \\
\text { (min) }\end{array}$ & $\begin{array}{c}\text { Mn } \\
\text { (Daitons) }\end{array}$ & $\begin{array}{c}\text { KR } \\
\text { (Daitons) }\end{array}$ & $\begin{array}{c}\text { Mw } \\
\text { (Daitons) }\end{array}$ & \multicolumn{1}{c|}{$\begin{array}{c}\text { Mz } \\
\text { (Daitons) }\end{array}$} & $\begin{array}{c}\text { Mz+1 } \\
\text { (Daltons) }\end{array}$ & Polydlspersity \\
\hline 1 & 14.817 & 386 & 453 & 121 & 155 & 192 & 1.091709 \\
\hline
\end{tabular}

Figure 16: Gel Permeation Chromatography Curve for C-300-3, Hydrotreated Coal $450^{\circ} \mathrm{C}-2$ Hours, No Catalyst 
Project Name: GPC Sample Name:

vial:

$701-2-16-8$

Injection:

Date Acquired:

Processing Method:

Comments:

1

GPC
Sample Type: Broad Unknown

Volume:

Run Time:

100.00

30.0 min

06/16/95 01:23:06 PM

Pressure:

06/19/95 09:37:30 AM

75

Submitter: RTL

C300-6, Ee Cat. 450-2 prepped 6/15/95 .25g/7ml TCB no fl. rt. mkr. 95060801

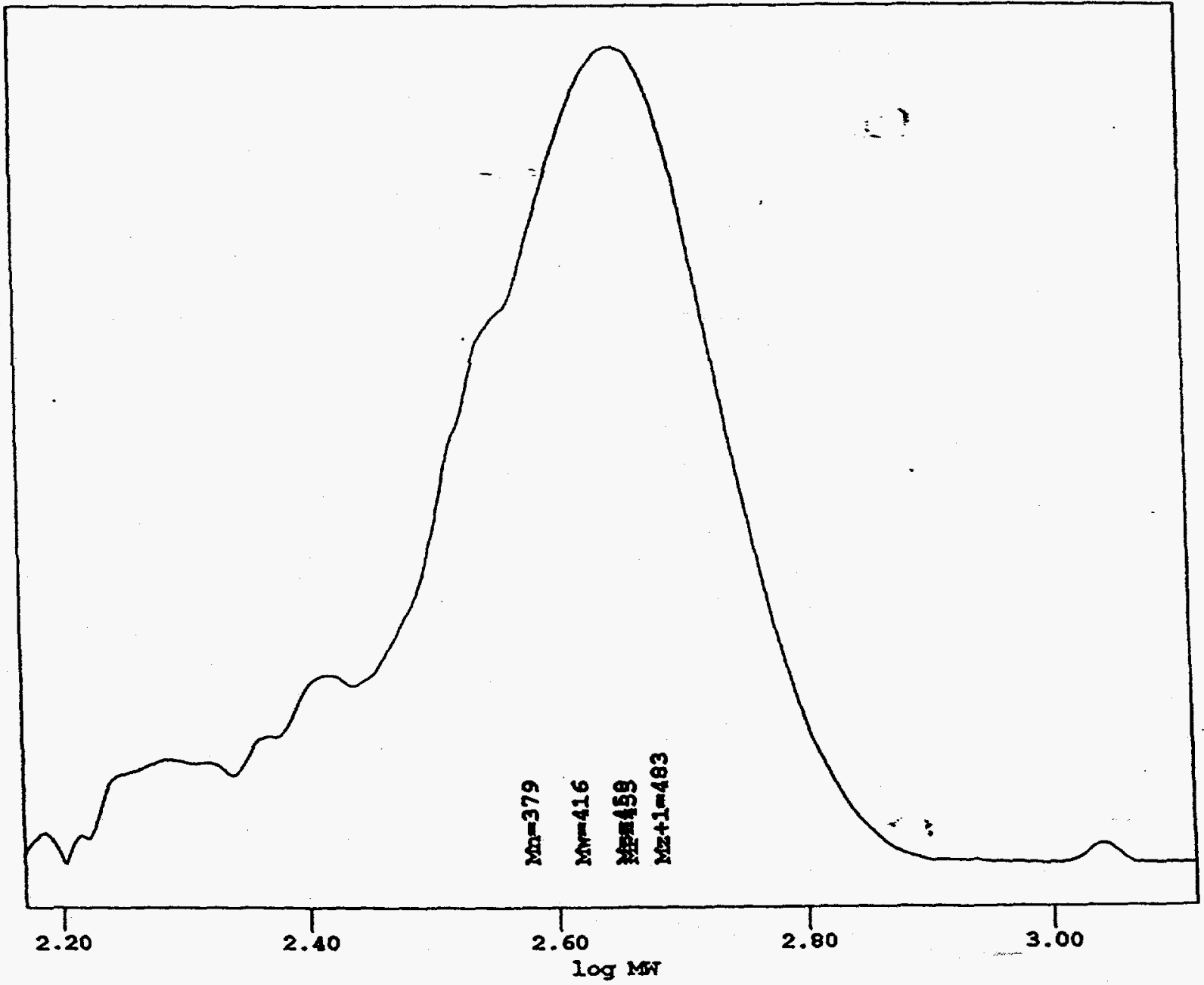

Start Time: 9.200 End Time: 20.800

Peak Results

\begin{tabular}{|c|c|c|c|c|c|c|c|}
\hline 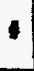 & $\begin{array}{l}\text { Ret Time } \\
\text { (min) }\end{array}$ & $\stackrel{\text { Mn }}{\text { (Dajtons) }}$ & $\underset{\text { (Daltons) }}{\text { MP }}$ & $\underset{\text { (Daltons) }}{M}$ & $\stackrel{M z}{M}$ & $\begin{array}{c}M(z+1 \\
\text { (Daltons) }\end{array}$ & Rolydl spersity \\
\hline 1 & 14.783 & 379 & 155 & 416 & 150 & 483 & 1.096545 \\
\hline
\end{tabular}

Figure 17: Gel Permeation Chromatography Curve for C-300-6, Hydrotreated Coal $450^{\circ} \mathrm{C}-2$ Hours, $\mathrm{Fe}_{2} \mathrm{~S}_{3}$ Catalyst 
Project Name: GPC

Sample Name:

vial:

Injection:

bate Acquired:

Processing Method:

Comments:

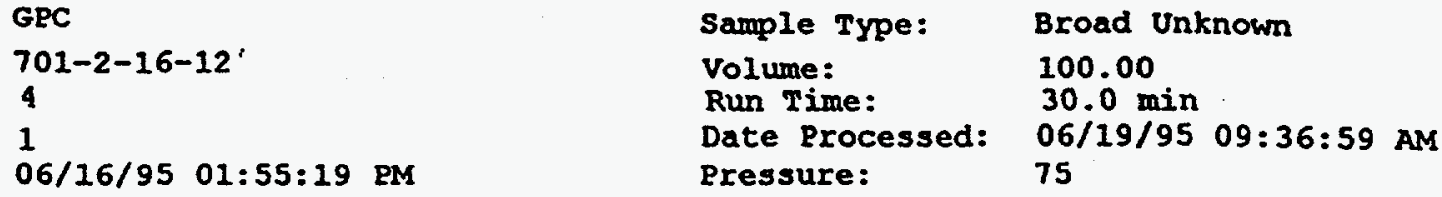

Sample Type: Broad Unknown

Volume: 100.00

Run Time:

30.0 min

Date Processed: 06/19/95 09:36:59 AM

Pressure:

75

submitter: $\quad$ RTI

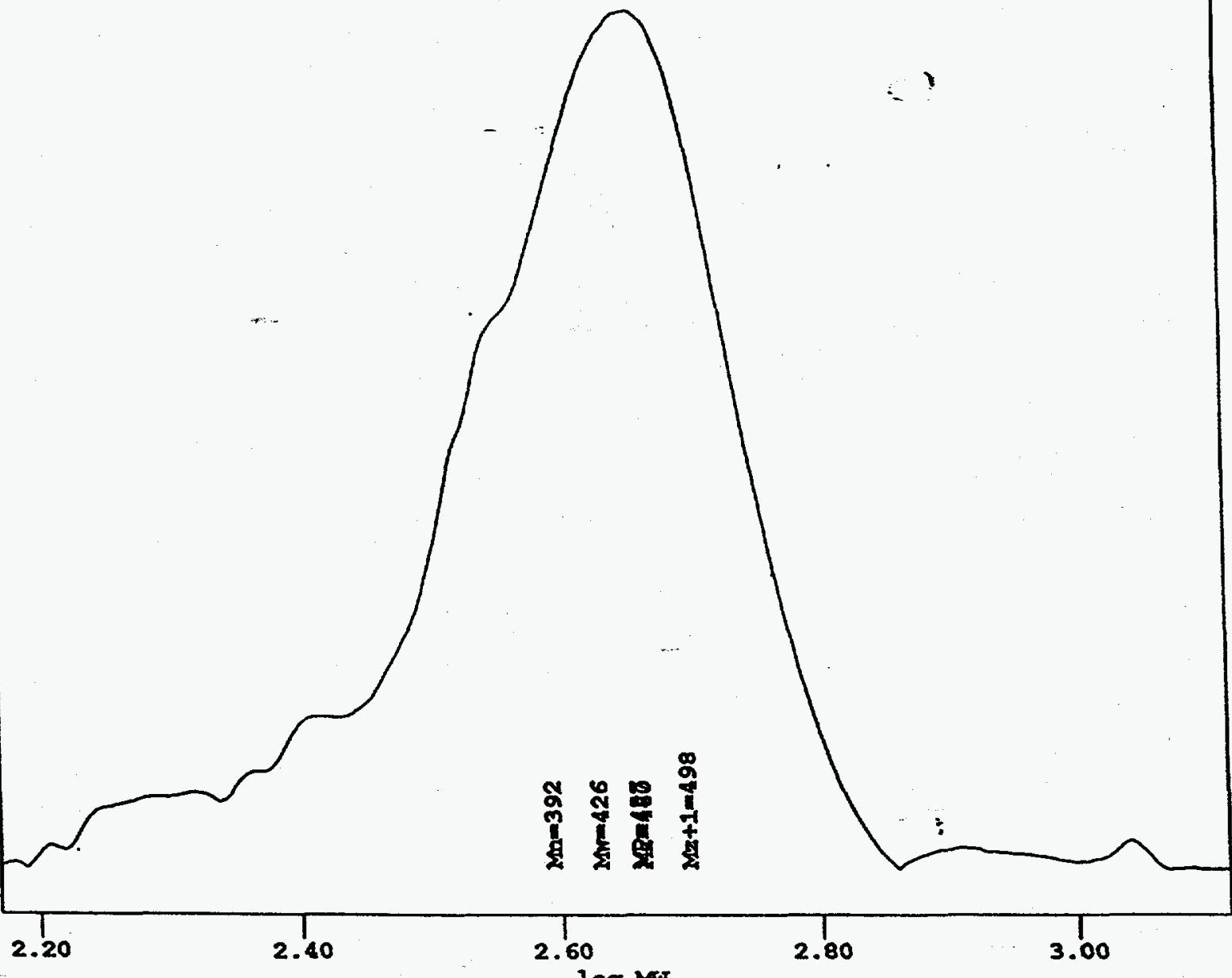

start Time: 9.200 Ind wime: 20.800

Peak Results

\begin{tabular}{|c|c|c|r|r|r|r|r|}
\hline 1 & $\begin{array}{c}\text { Ret Iime } \\
\text { (min) }\end{array}$ & $\begin{array}{c}\text { Mn } \\
\text { (Daitons) }\end{array}$ & $\begin{array}{c}\text { MP } \\
\text { (Daltons) }\end{array}$ & $\begin{array}{c}\text { Mw } \\
\text { (Daltons) }\end{array}$ & $\begin{array}{c}\text { Mz } \\
\text { (Daltons) }\end{array}$ & $\begin{array}{c}\text { Mz+1 } \\
\text { (Daltons) }\end{array}$ & Polydispersity \\
\hline 1 & 14.767 & 392 & 157 & 126 & 460 & 198 & 1.087104 \\
\hline
\end{tabular}

Figure 18: Gel Permeation Chromatography Curve for C-300-9, Hydrotreated Coal $450^{\circ} \mathrm{C}-2$ Hours, Mo(S) Catalyst 


\section{PRODUCTS FROM $400^{\circ} \mathrm{C}-6$ HR. HEAT TREATMENTS OF WVU COAL EXTRACTS}

(Schematic Diagram)

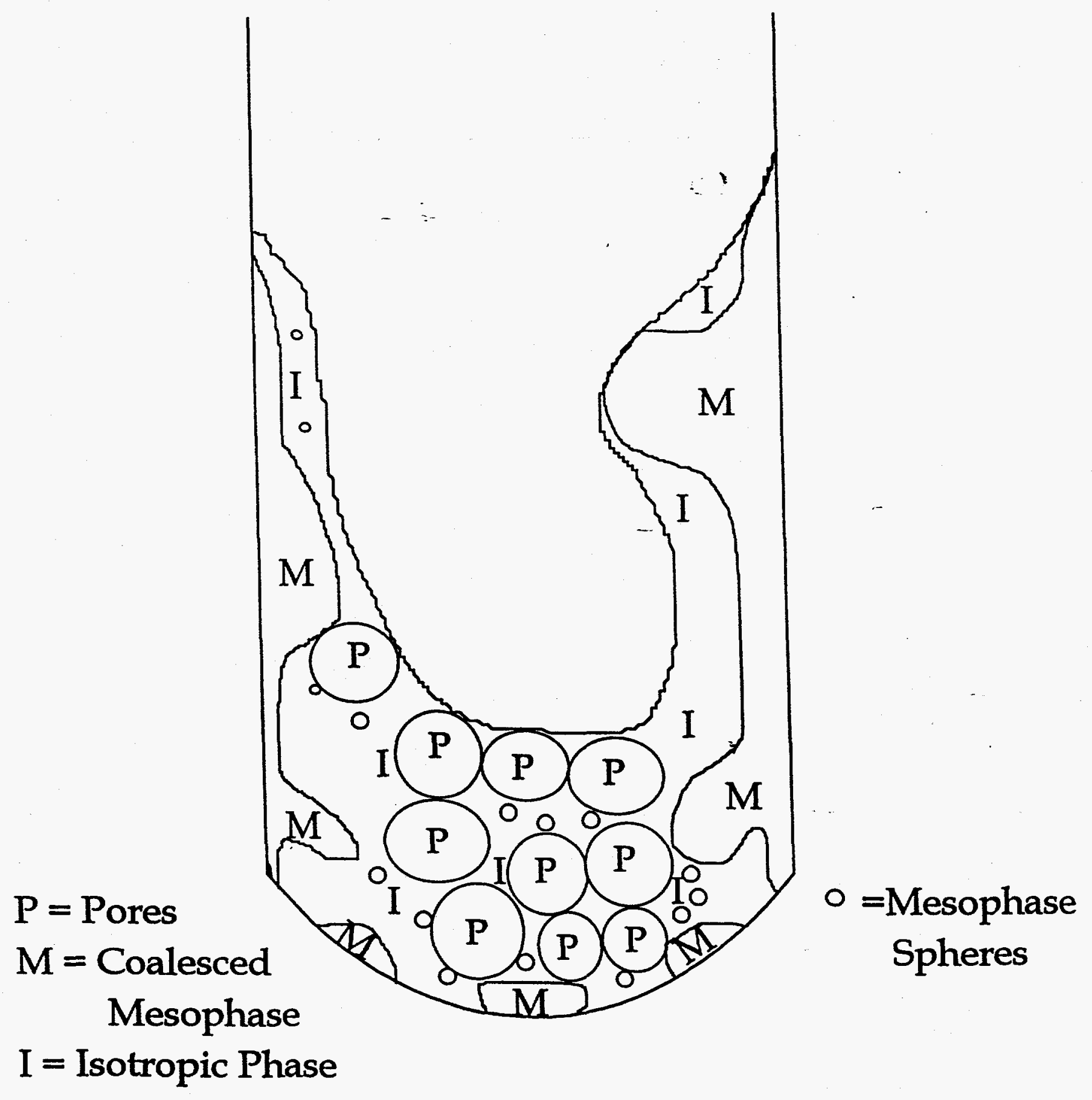


+m +10

.

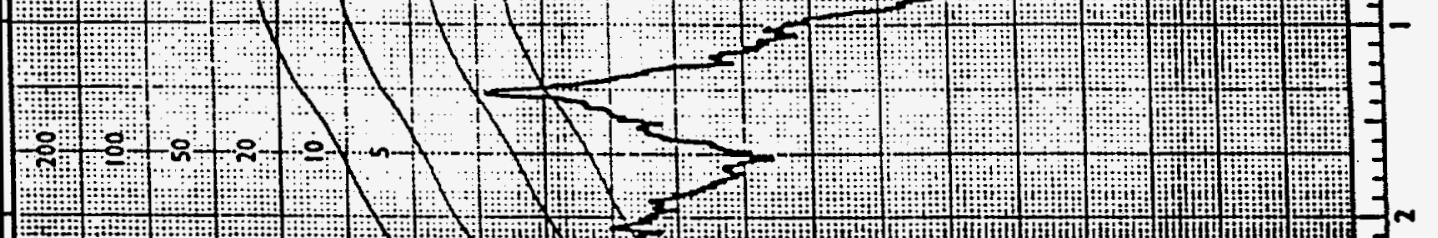

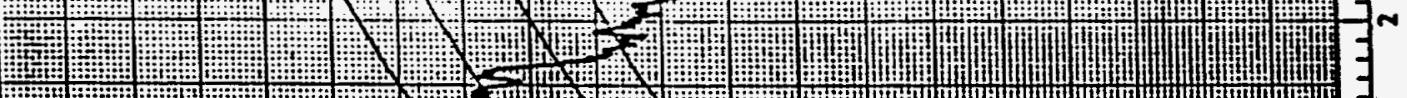
- $2+1$ Of

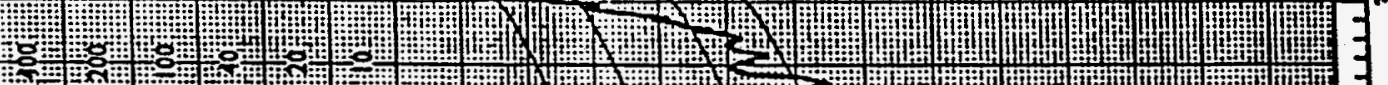

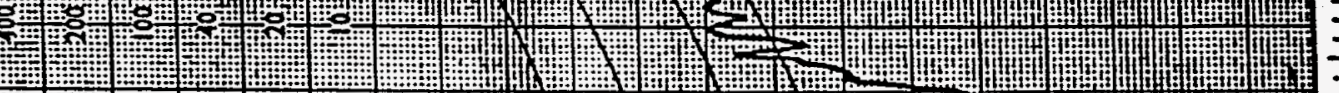

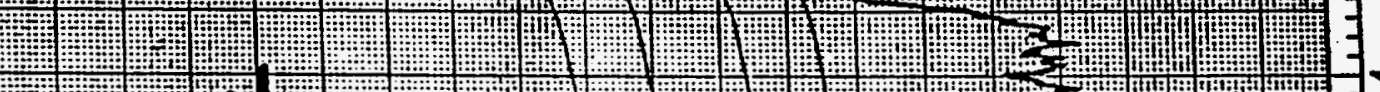
F

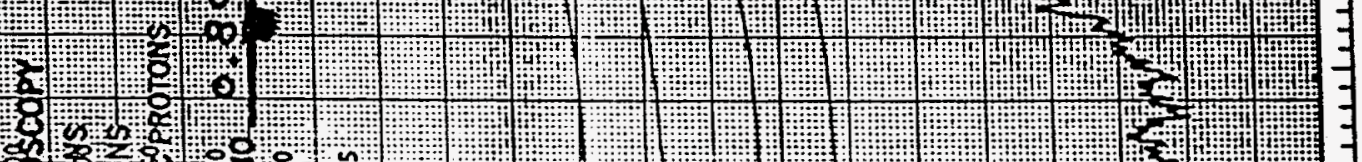
28 (a) Put e S2

\#

$\sqrt{3}$

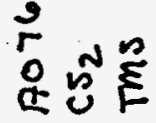

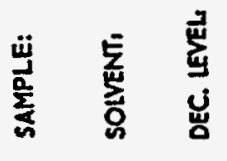

$\left.\right|_{3}$

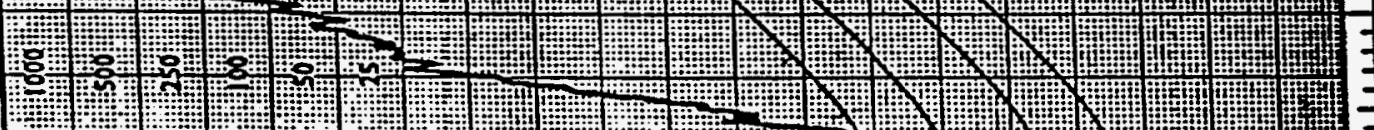

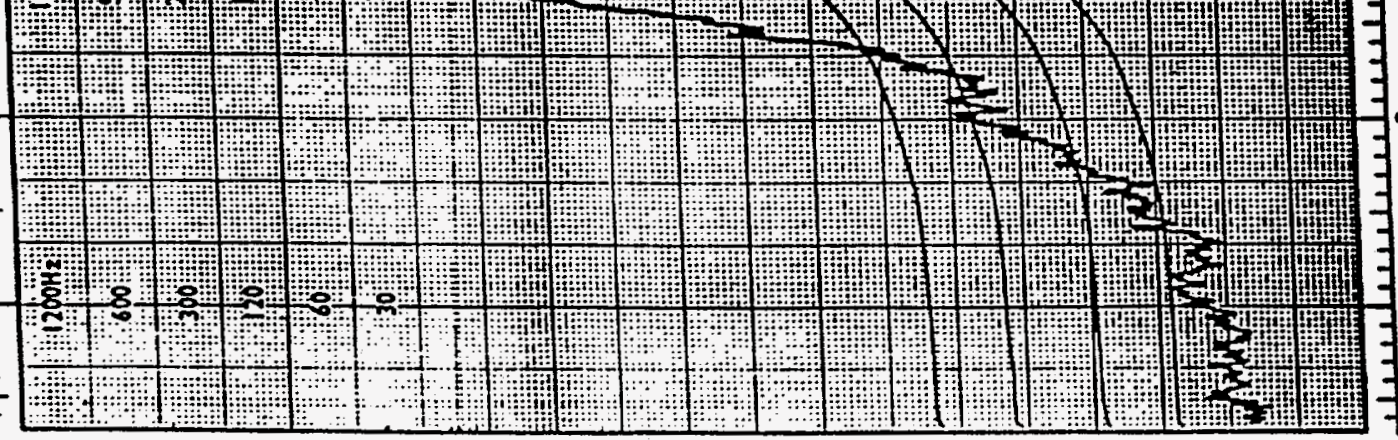

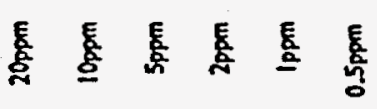

F1gure 20: Proton NMR Spectrum for A076 from Hydrotreated Coa1 WVGS $-13421-450^{\circ} \mathrm{C}, 2$ : Hours 


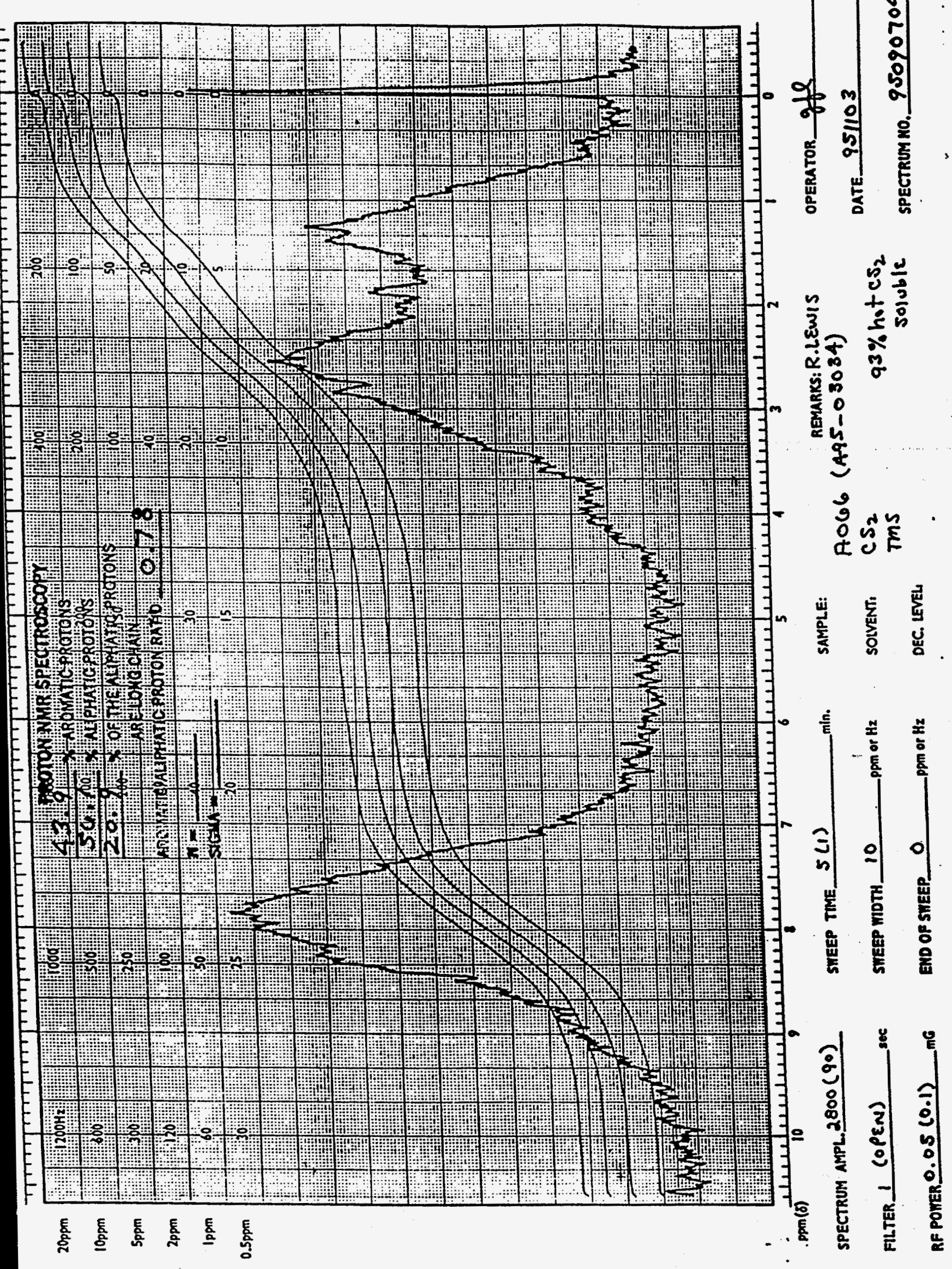

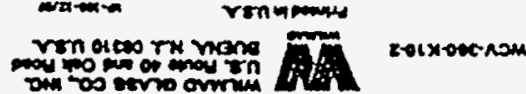

Figure 21: Proton NMR Spectrum for A066 from Hydrotreated Coal WVGS $-13421-450^{\circ} \mathrm{C}, 1$ Hour 


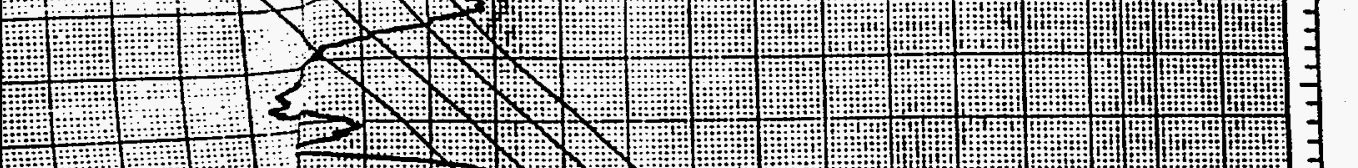

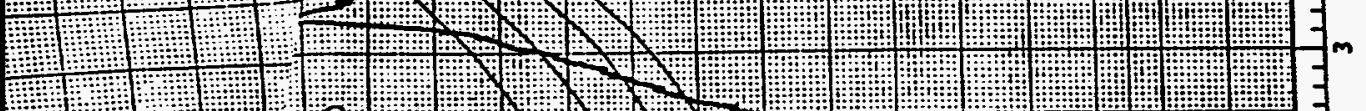

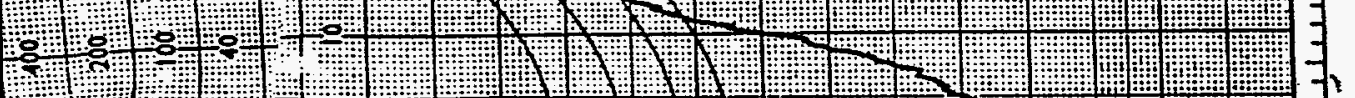

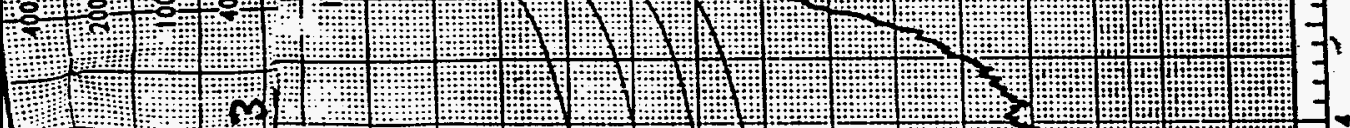

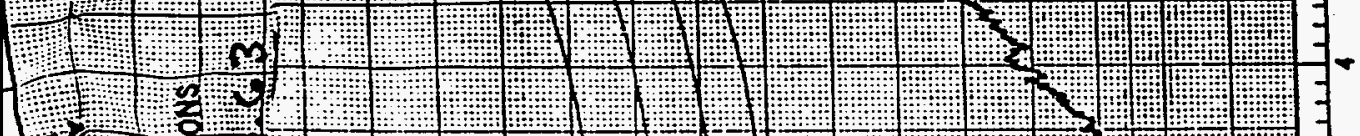

F)

fE 0 :

to $3 \geq 0$

Lelo

(a)

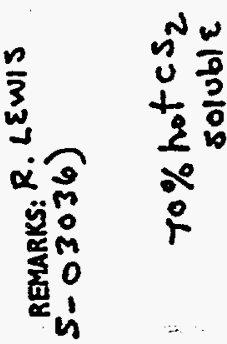

焉

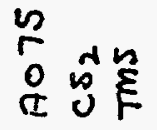

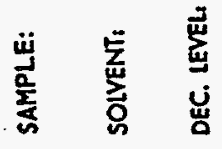

|

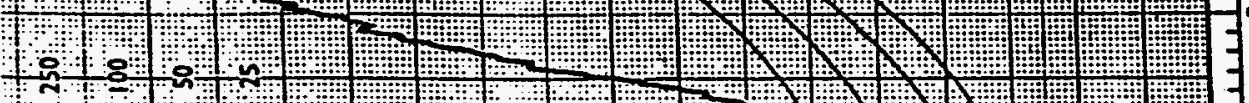

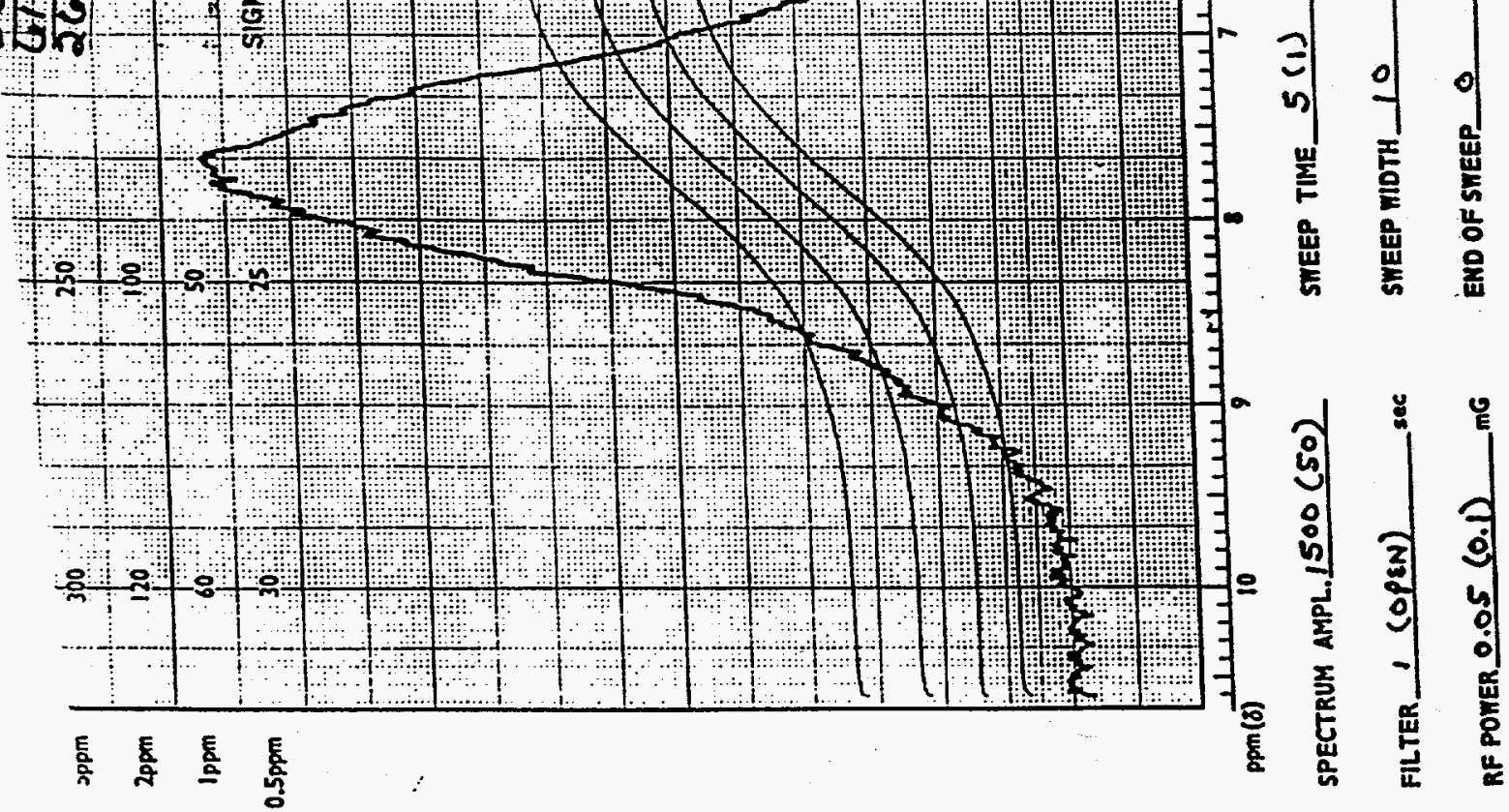

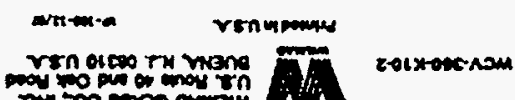

Figure 23: Proton NMR Spectrum for A075 from Hydrotreated Coal WVGS- $13423-450^{\circ} \mathrm{C}, 1$ Hour 


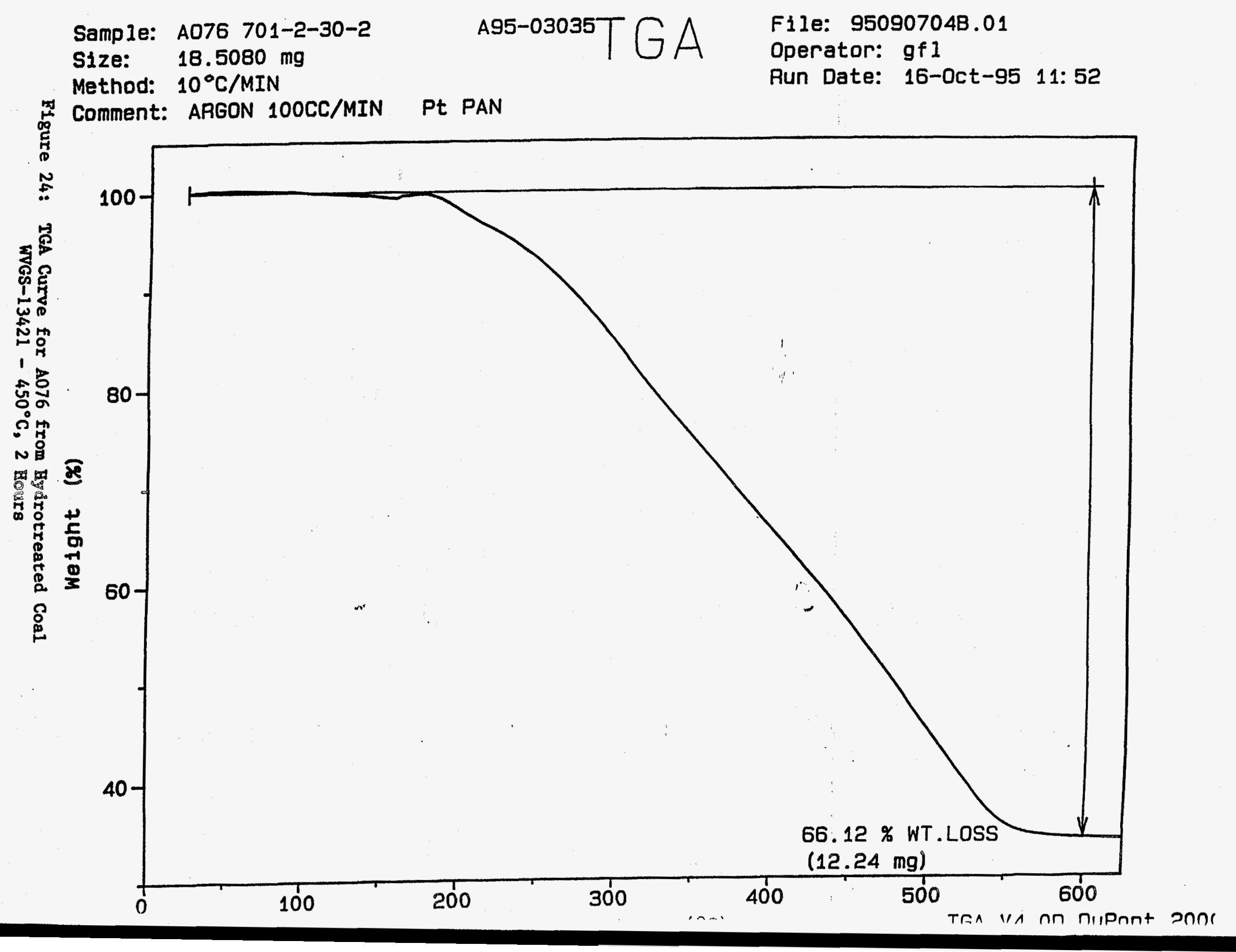




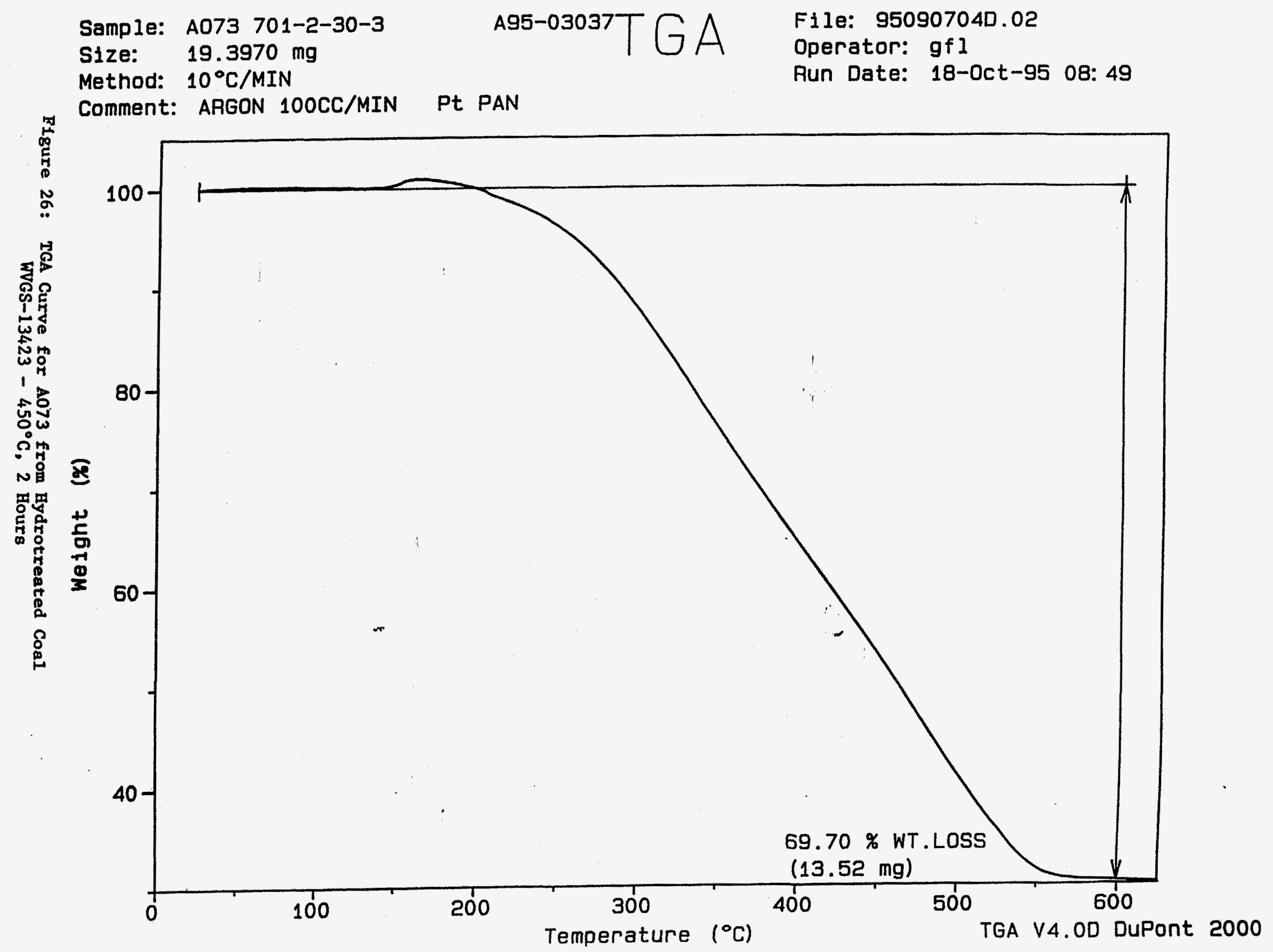




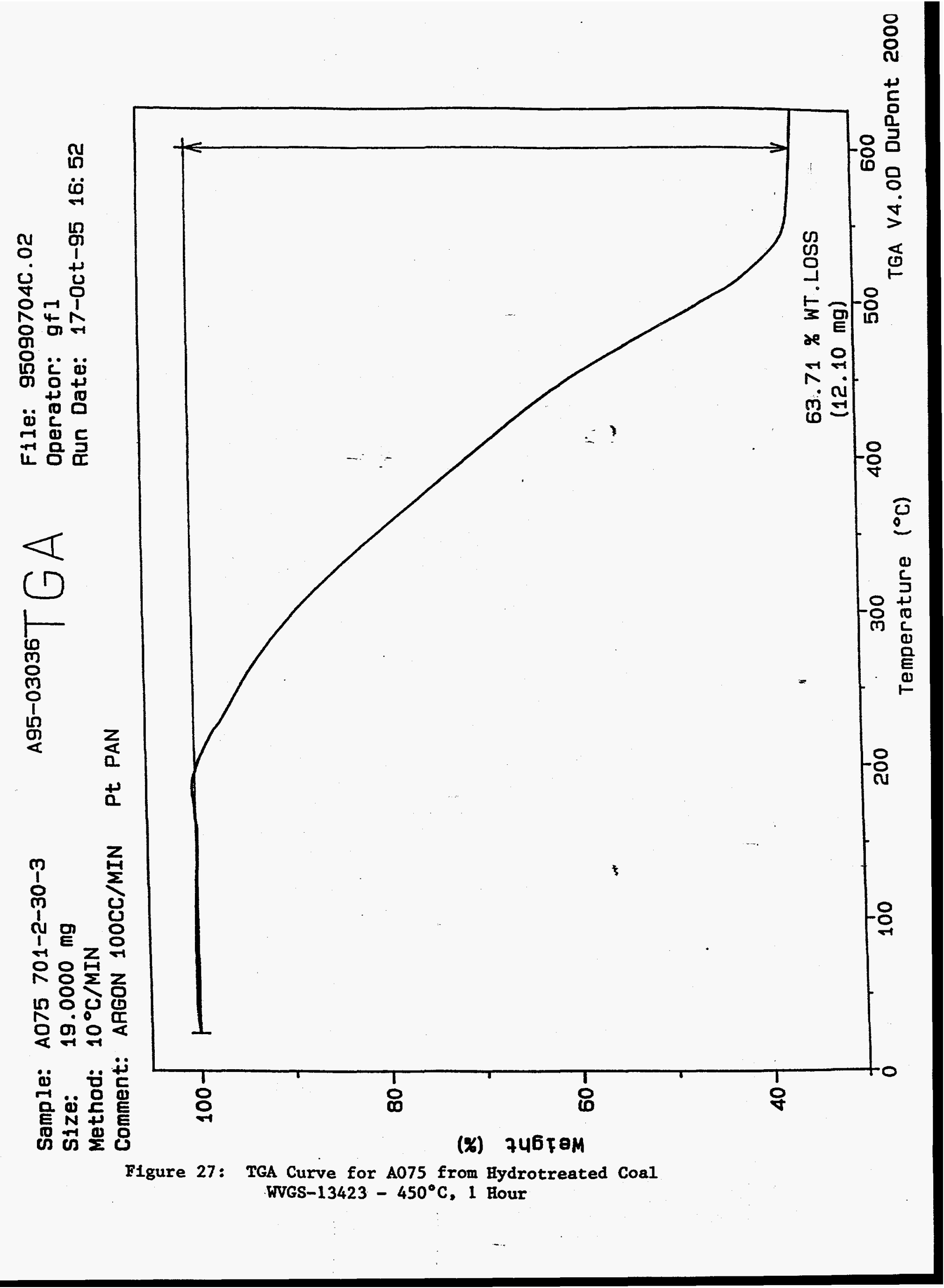


Project Name:

Sample Name:

Vial:

Injection:

Date Acquired:

Processing Method:

Comments :
GPC

A076

4

1

09/25/95 02:08:13 PM

GPC

701-2-30-2 (WVU) prepped 7/21/95
Sample Type:

Volume:

Run Time:

Date Processed:

Pressure:

Submitter:
Broad Unknown

100.00

$30.0 \mathrm{~min}$

09/25/95 03:49:51 PM 73

rtI

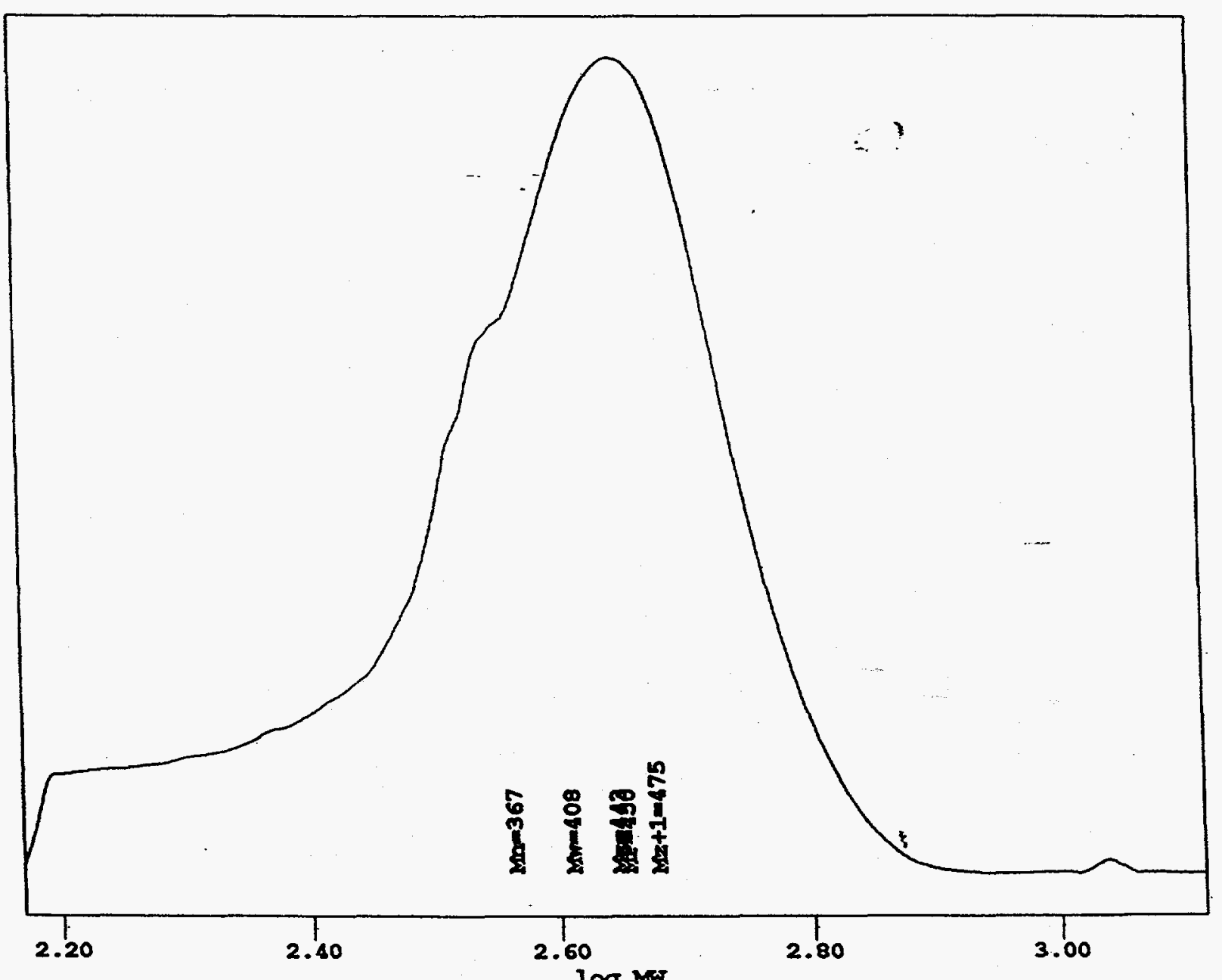

8tart Fime: 9.200 fnd rime: 20.800

Peak Results

\begin{tabular}{|c|c|c|r|r|r|r|r|}
\hline 1 & $\begin{array}{c}\text { Ret rime } \\
\text { (min) }\end{array}$ & $\begin{array}{c}\text { Mn } \\
\text { (Daitions) }\end{array}$ & $\begin{array}{c}\text { MP } \\
\text { (Daitons) }\end{array}$ & $\begin{array}{c}\text { Mw } \\
\text { (Daitons) }\end{array}$ & $\begin{array}{c}\text { Mz } \\
\text { (Daltons) }\end{array}$ & $\begin{array}{c}\text { Mz+1 } \\
\text { (Daltons) }\end{array}$ & Polydispersity \\
\hline 1 & 14.850 & 367 & 150 & 108 & 143 & 175 & 1.111614 \\
\hline
\end{tabular}

Figure 28: Gel Permeation Chromatogram for A076 from Hydrotreated Coal WVGS-13421 $-450^{\circ} \mathrm{C}, 2$ Hours 
Project Name: . GPC

Sample Name: A066

Vial:

Injection:

Date Acquired:

Processing Method:

Corments:
3

09/25/95 01:11:58 PM

GPC

701-2-30-1(WVU) prepped $7 / 21 / 95$
Sample Type:

Volume:

Run Time:

Date Processed:

Pressure:

submitter:
Broad Unknown

100.00

$30.0 \mathrm{~min}$

09/25/95 03:48:09 PM 73

rtl

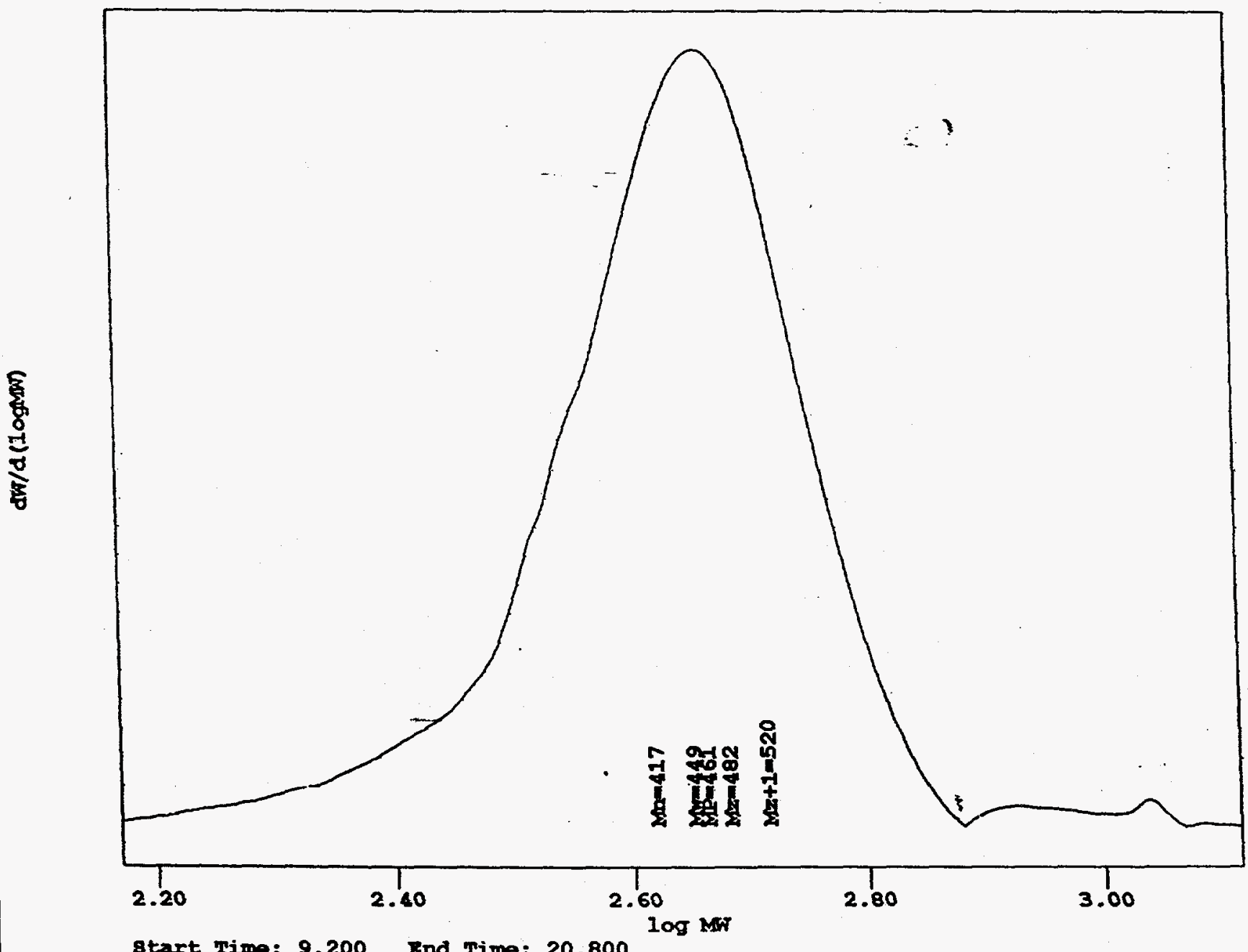

Peak Results

\begin{tabular}{|c|c|c|c|c|c|c|c|}
\hline 1 & $\begin{array}{c}\text { Ret Time } \\
\text { (min) }\end{array}$ & $\begin{array}{c}\text { Mn } \\
\text { (Daltons) }\end{array}$ & $\underset{\text { (Deltons) }}{\text { MP }}$ & (Daltons) & $\begin{array}{c}\mathrm{Mz} \\
\text { (Daltons) }\end{array}$ & $\begin{array}{c}M z+1 \\
\text { (Daltons) }\end{array}$ & Polydispersity \\
\hline 1 & 14.717 & 117 & 461 & 149 & 482 & 520 & 1.076375 \\
\hline
\end{tabular}

Figure 29: Gel Permeation Chromatogram for A066 from Hydrotreated Coa1 WVGS- $13421-450^{\circ} \mathrm{C}, 1$ Hour 


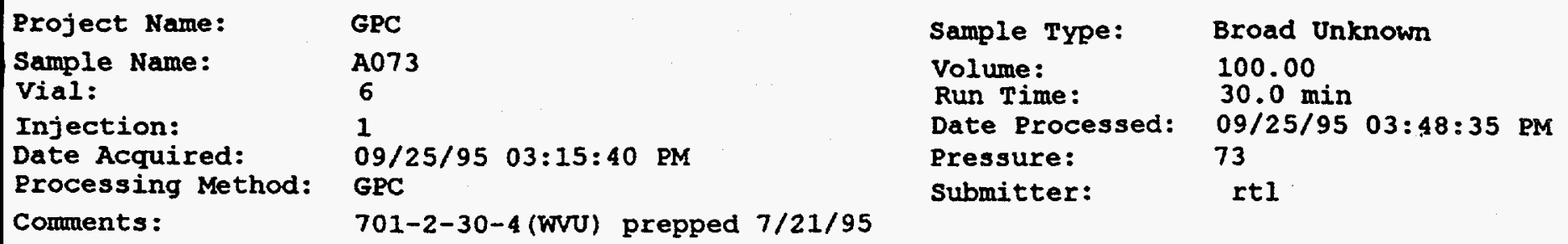

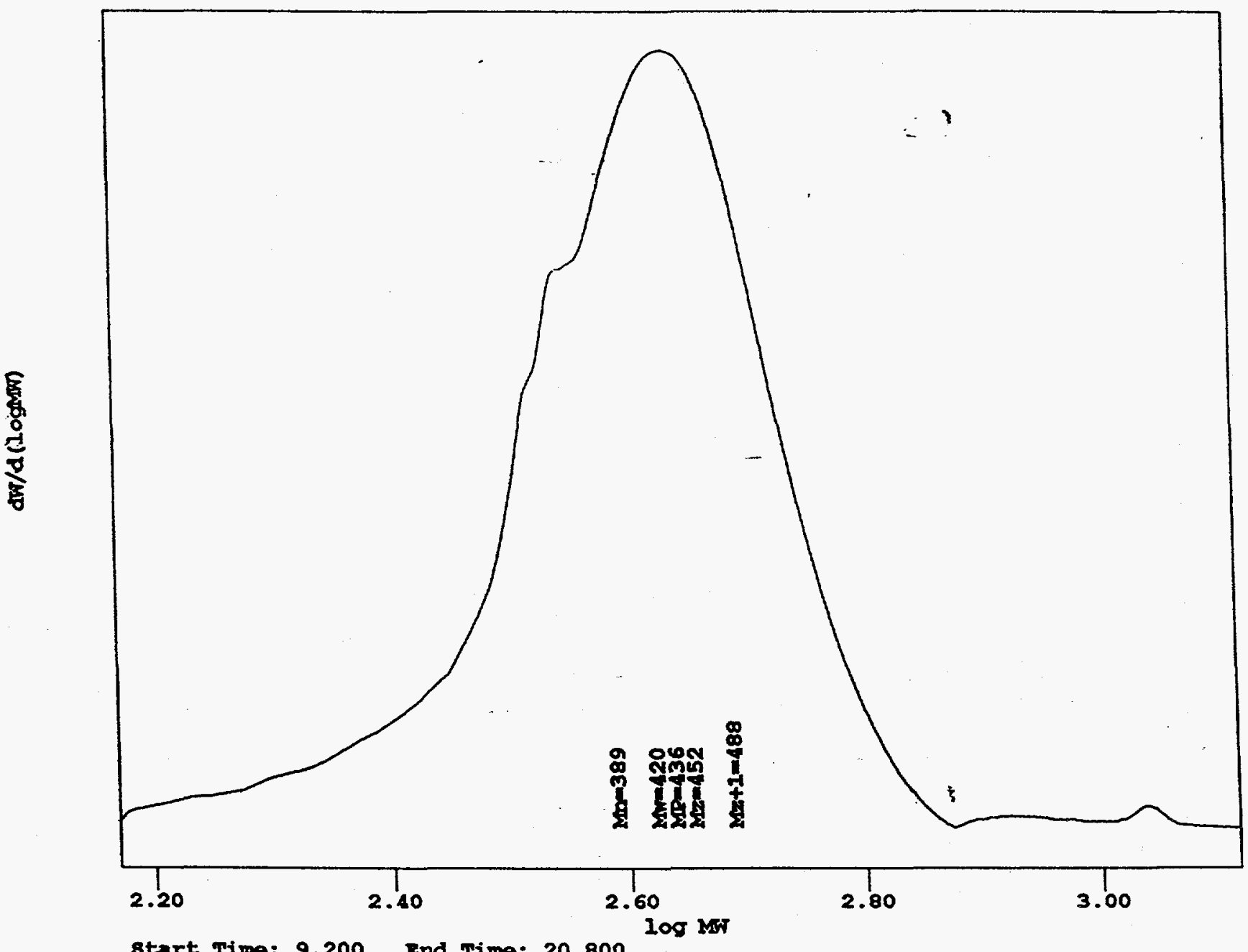

Btart Time: 9.200 End Time: 20.800

Peak Results

\begin{tabular}{|c|c|r|r|r|r|r|r|}
\hline & $\begin{array}{c}\text { Ret Time } \\
\text { (Min) }\end{array}$ & $\begin{array}{c}\text { Mn } \\
\text { (Daitons) }\end{array}$ & $\begin{array}{c}\text { MP } \\
\text { (Daltons) }\end{array}$ & $\begin{array}{c}\text { Mw } \\
\text { (Deitons) }\end{array}$ & $\begin{array}{c}\text { Mz } \\
\text { (Daltons) }\end{array}$ & $\begin{array}{c}\text { Mz+1 } \\
\text { (Daltons) }\end{array}$ & Polydispersity \\
\hline 1 & 15.017 & 389 & 436 & 420 & 452 & 188 & 1.079811 \\
\hline
\end{tabular}

Figure 30: Gel Permeation Chromatogram for A073 from Hydrotreated Coal WVGS-13423 - $450^{\circ} \mathrm{C}, 2$ Hours 
Project Name: Sample Name:

Vial:

Injection:

Date Acquired:

Processing Method:

Comments :
GPC

A075

5

1

09/25/95 02:44:30 PM

GPC

701-2-30-3 (WvU) prepped 7/21/95
Sample Type: Broad Unknown

Volume:

Run Time:

Processed: 09/25/95 03:49:10 PM

Pressure:

Submitter:
100.00 73

rtl

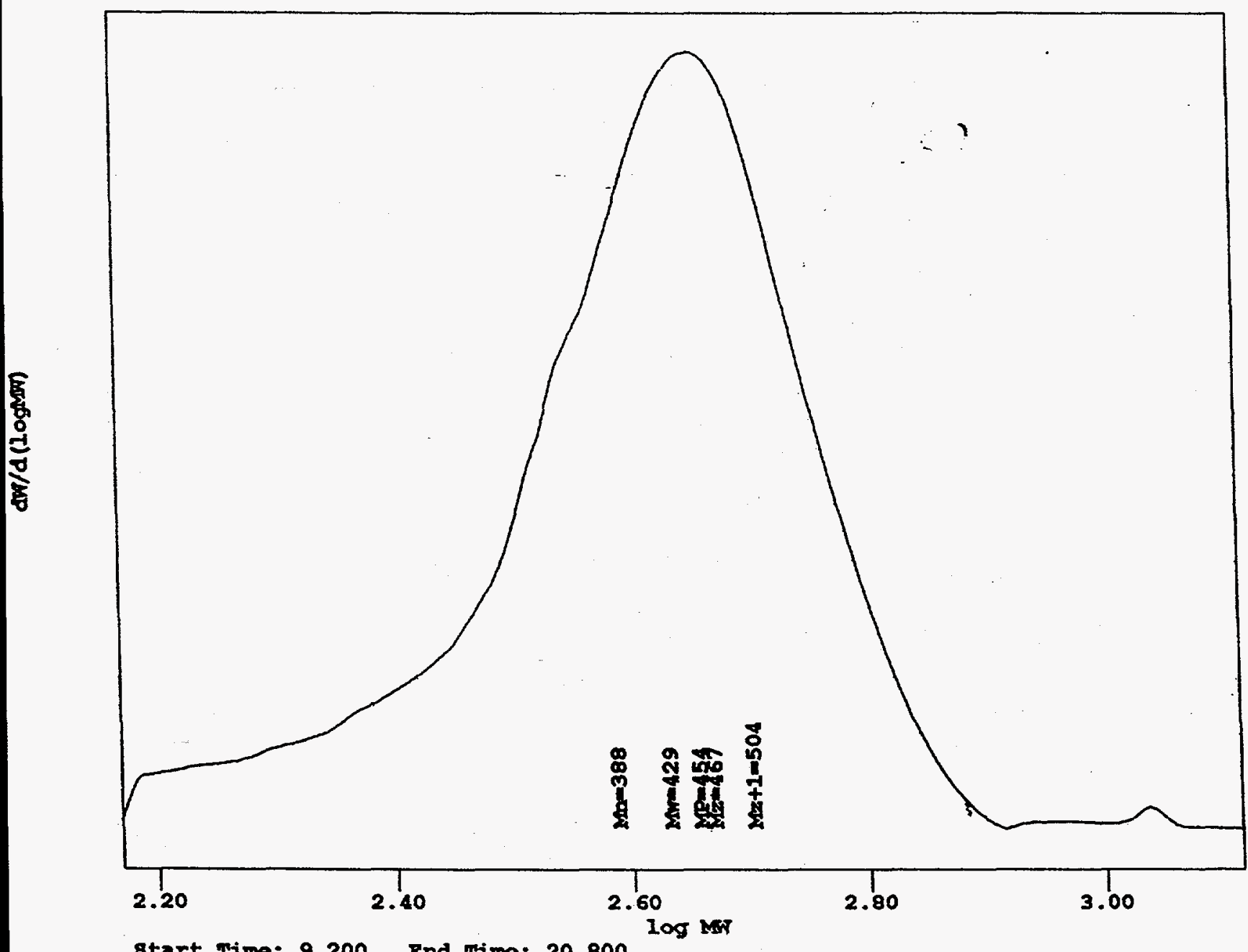

Peak Results

\begin{tabular}{|c|c|c|c|c|c|c|c|}
\hline$F$ & $\begin{array}{c}\text { Ret Iime } \\
\text { (min) }\end{array}$ & $\begin{array}{c}\text { Mn } \\
\text { (Daltons) }\end{array}$ & $\underset{\text { (Daitons) }}{\text { MP }}$ & $\stackrel{M w}{\text { (Daltons) }}$ & $\begin{array}{c}\mathrm{Mz} \\
\text { (Daltons) }\end{array}$ & $\begin{array}{c}\mathrm{Mz+1} \\
\text { (Daltons) }\end{array}$ & Polydisperaity \\
\hline 1 & 14.800 & 388 & 154 & 129 & 167 & 504 & 1.106079 \\
\hline
\end{tabular}

Figure 31: Ge1. Permeation Chromatogram for A075 from Hydrotreated Coal WVGS $-13423-450^{\circ} \mathrm{C}, 1$ Hour 


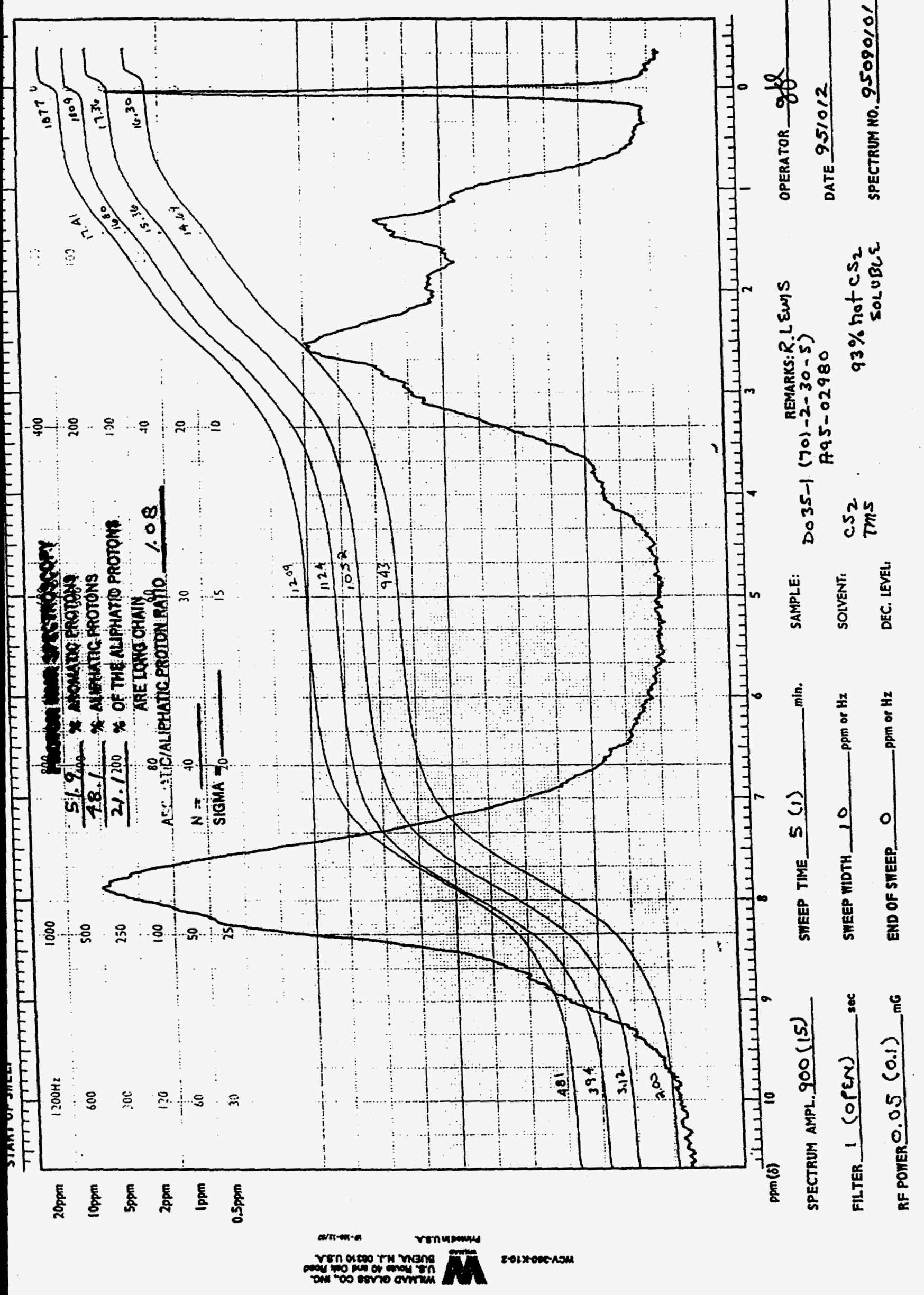

Figure 32: Proton NMR Spectrum for $250^{\circ} \mathrm{C}$ Distillation Resldue D035-1 


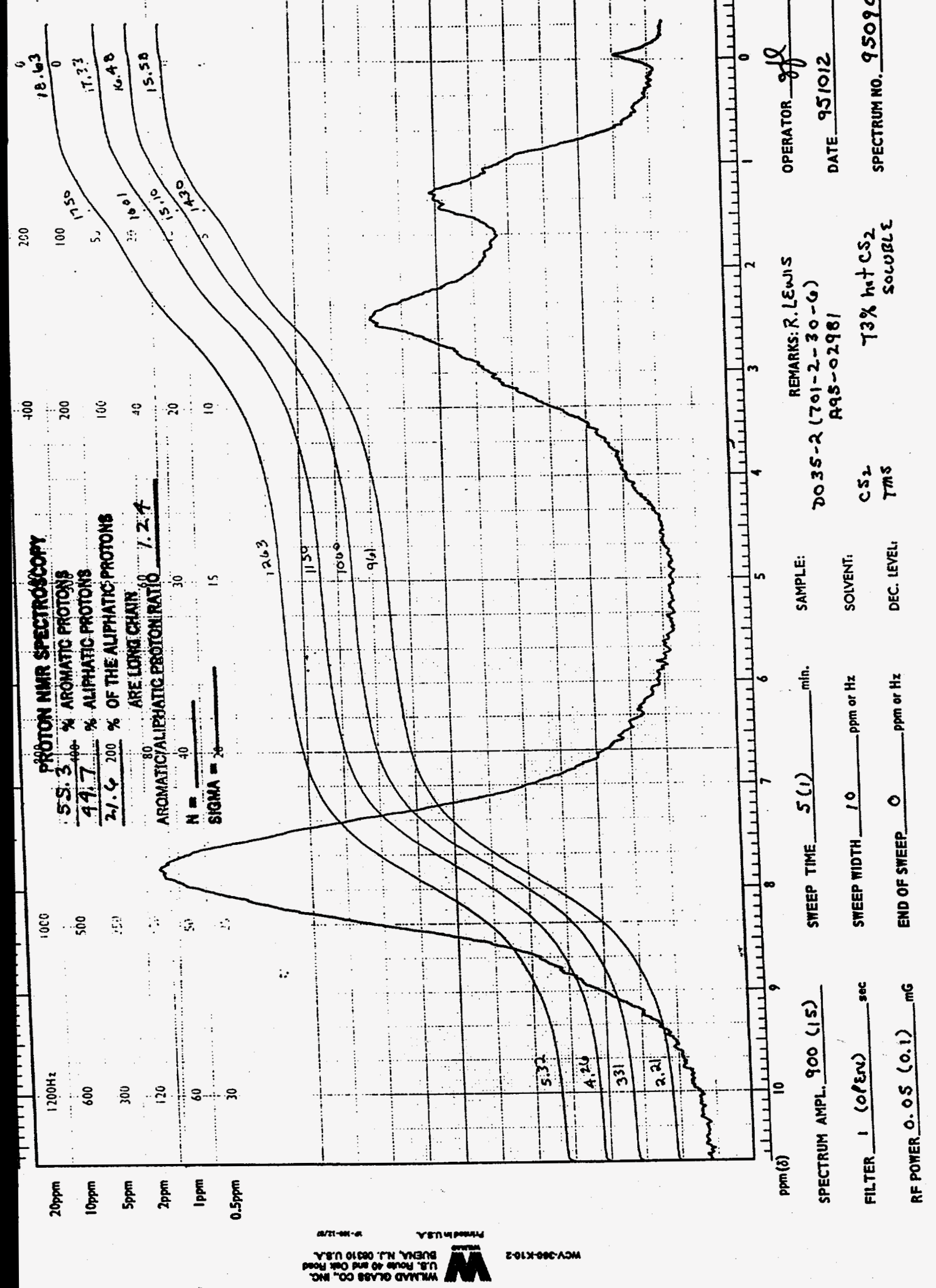

Figure 33: Proton MMR Spectrum for $350^{\circ} \mathrm{C}$ Dlstillation Residue D035-2 


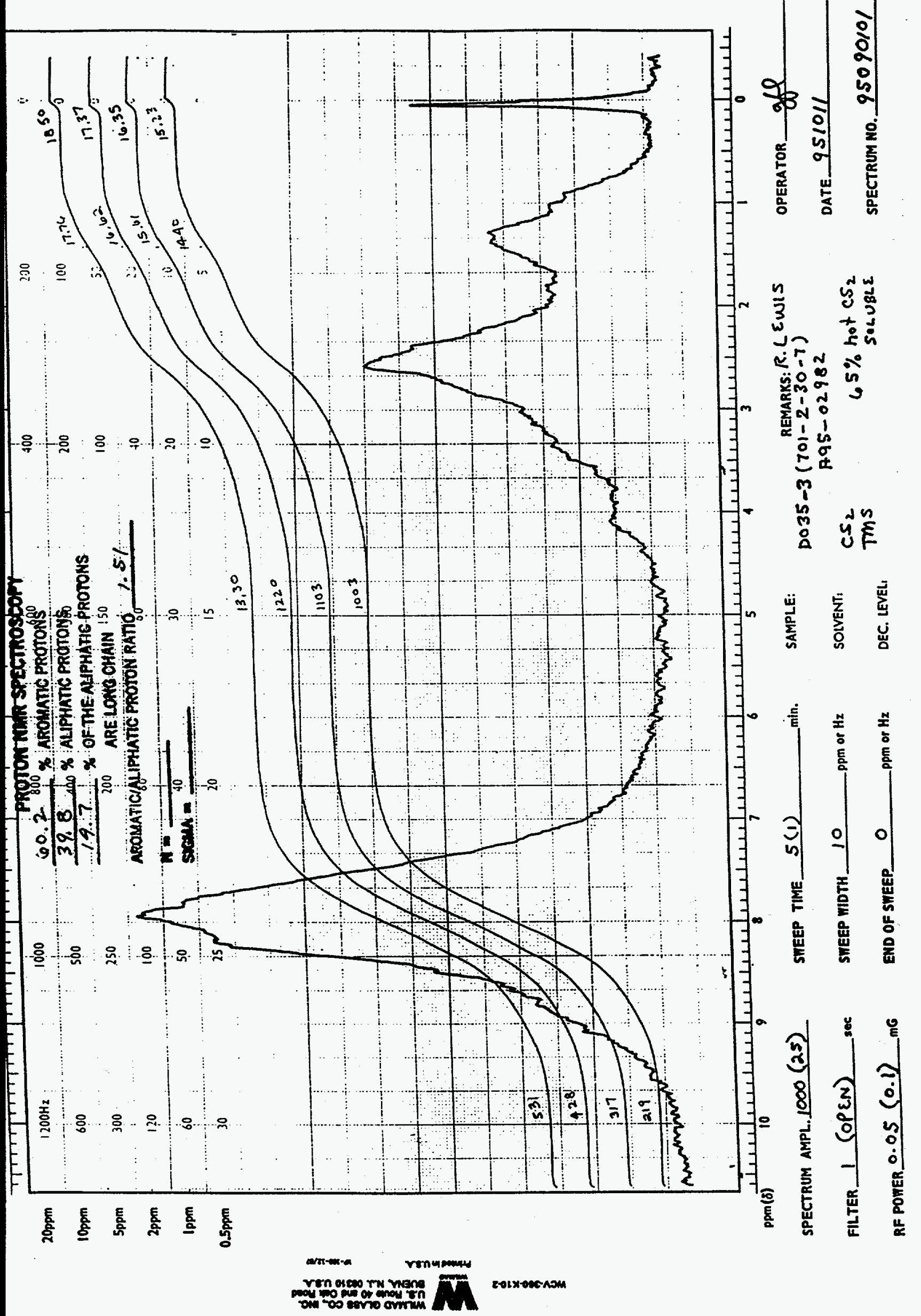

Figure 34: Proton NMR Spectrum for $400^{\circ} \mathrm{C}$ Dist11lation Residue D035-3 


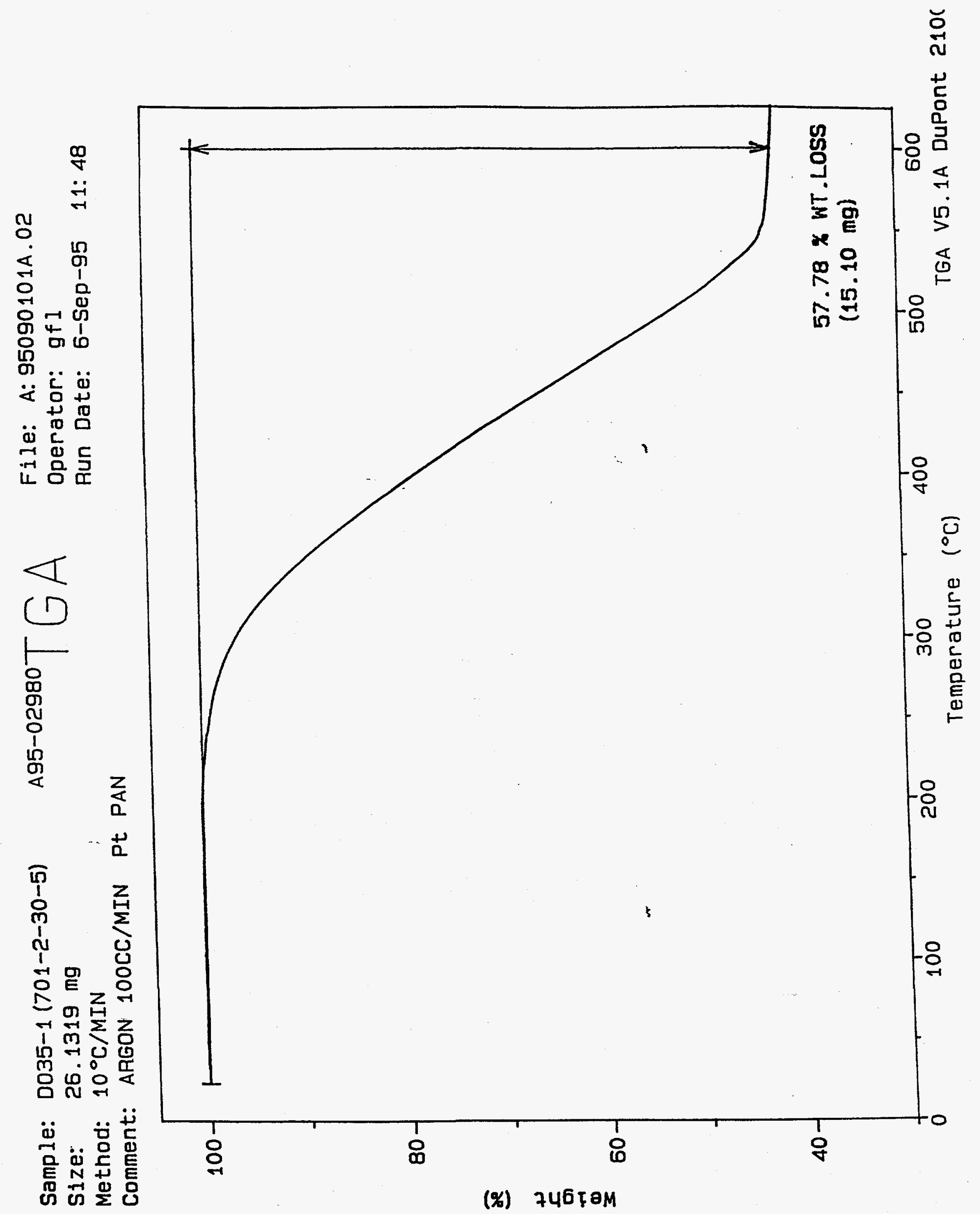

FIgure 35: TGA Curve for $250^{\circ} \mathrm{C}$ Dist111ation Residue D035-1 
Sample: $0035-2(701-2-30-6)$

Size: $\quad 26.2477 \mathrm{mg}$

File: A: $95090101 \mathrm{~B} .02$

Operator: gf 1

Method: $10^{\circ} \mathrm{C} / \mathrm{MIN}$

Run Date: 6-Sep-95 14: 12

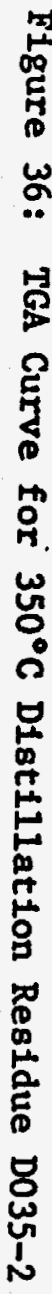

Comment: ARGON 100CC/MIN Pt PAN

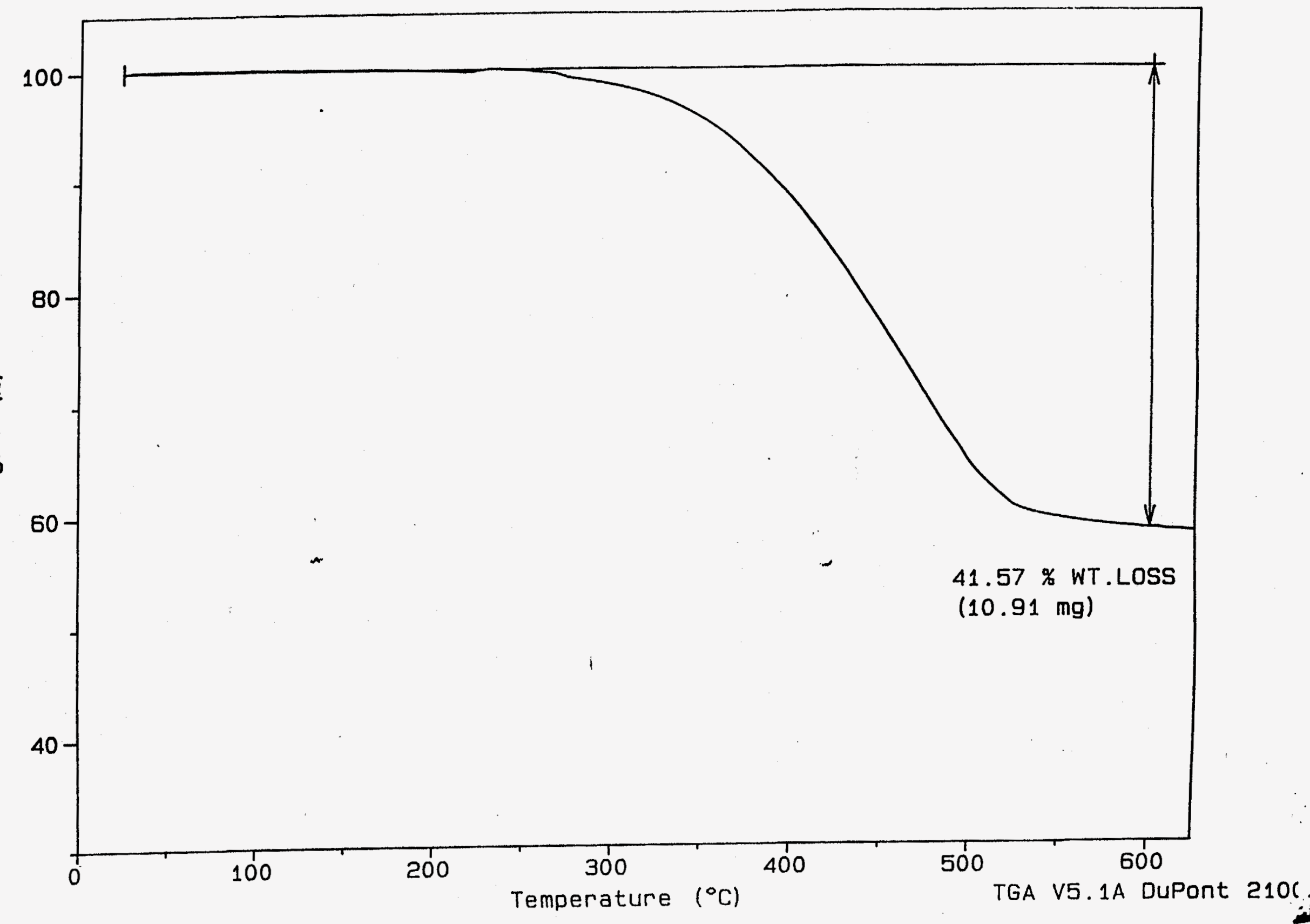




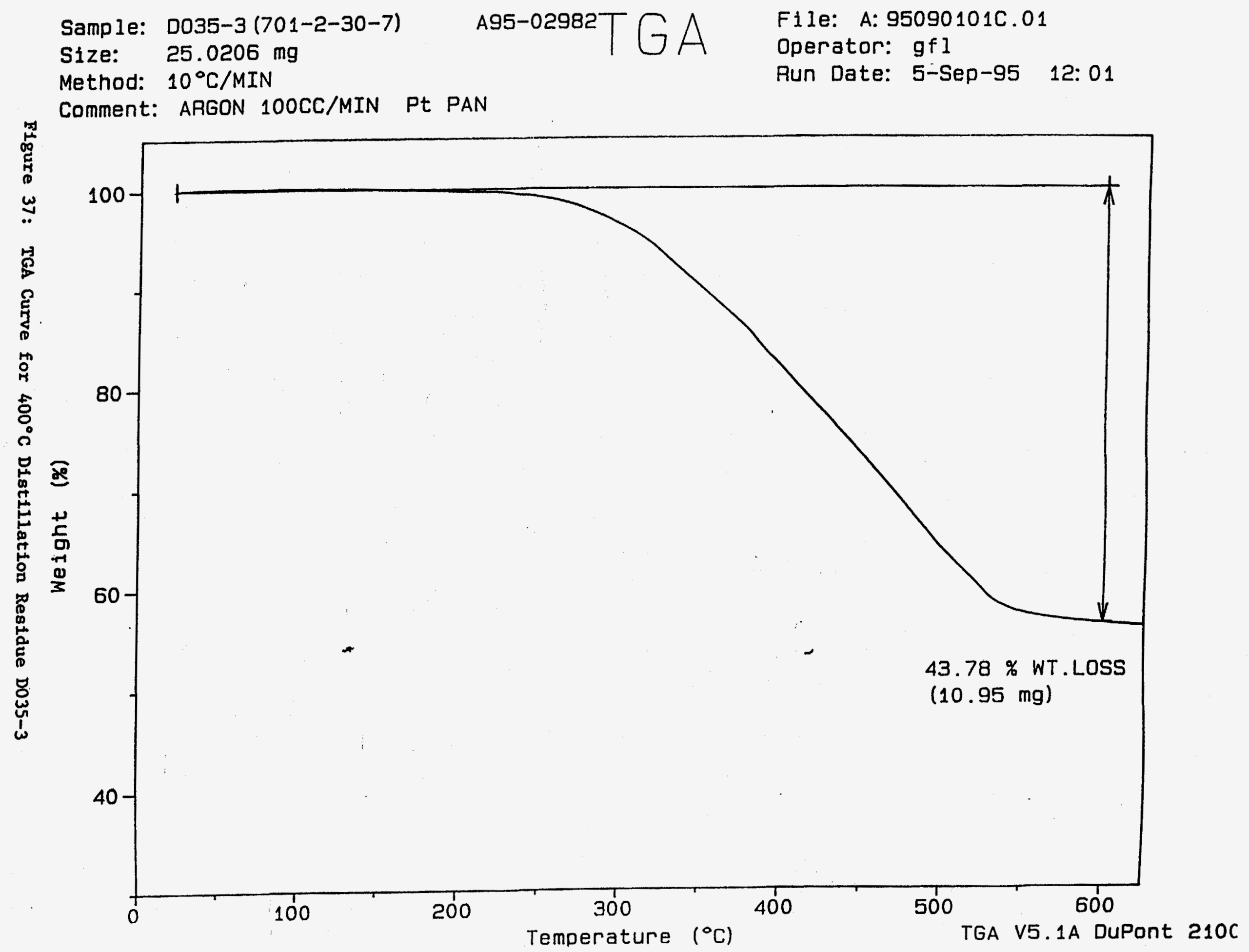


Annealed Mesophase Pitch from Sample A076

$$
450^{\circ} \mathrm{C} \text { - } 2 \text { Hr., Coal WVGS } 13421
$$

A076

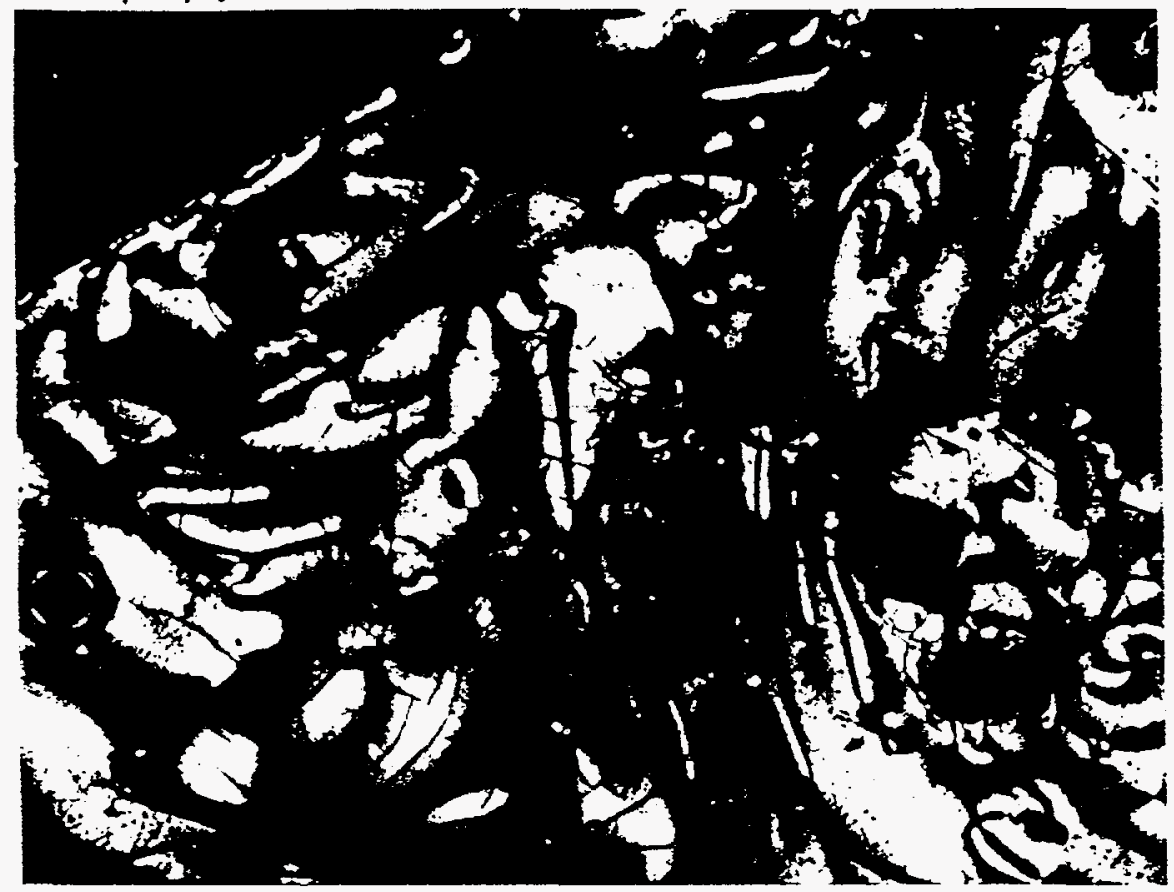

e:
$\times$
:

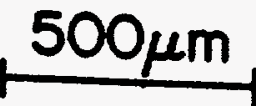

50X, POLARIZED LIGHT

\section{f.076}

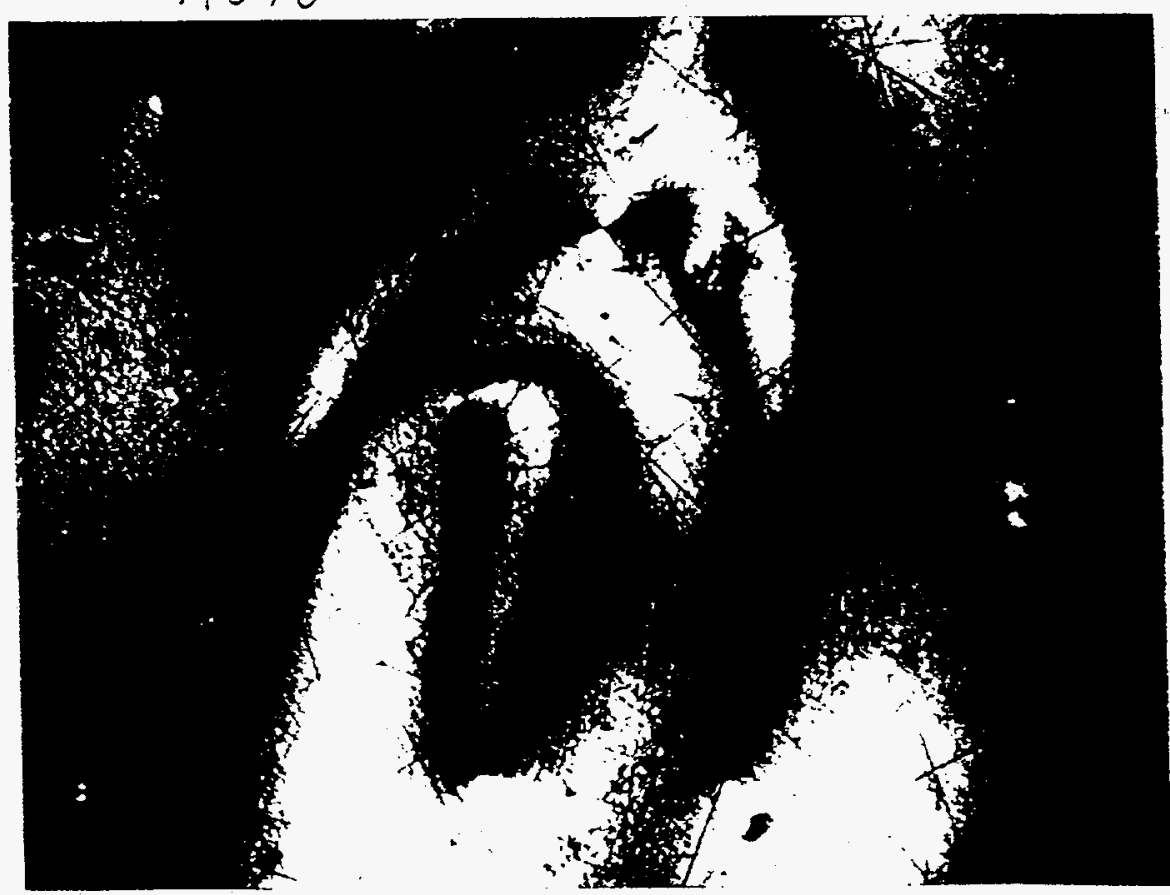

1
2
2

N:

$\therefore$

i:

$\frac{10}{\infty}$

$\infty$

sis 
Annealed Mesophase Pitch from Sample A066

$$
450^{\circ} \mathrm{C} \text { - } 1 \text { Hr., Coal WVGS } 13421
$$

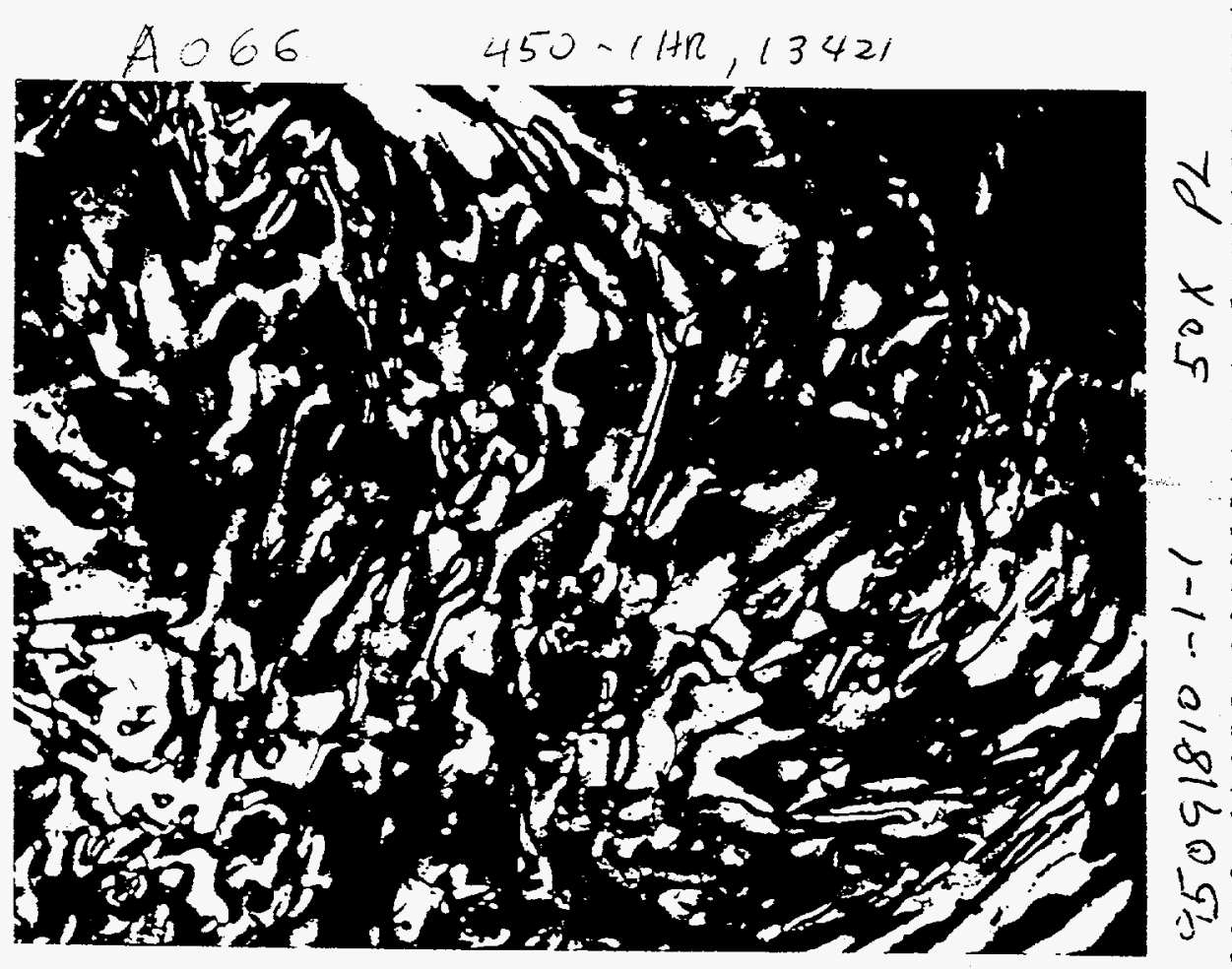

\section{X, POLARIZED LIGHT}

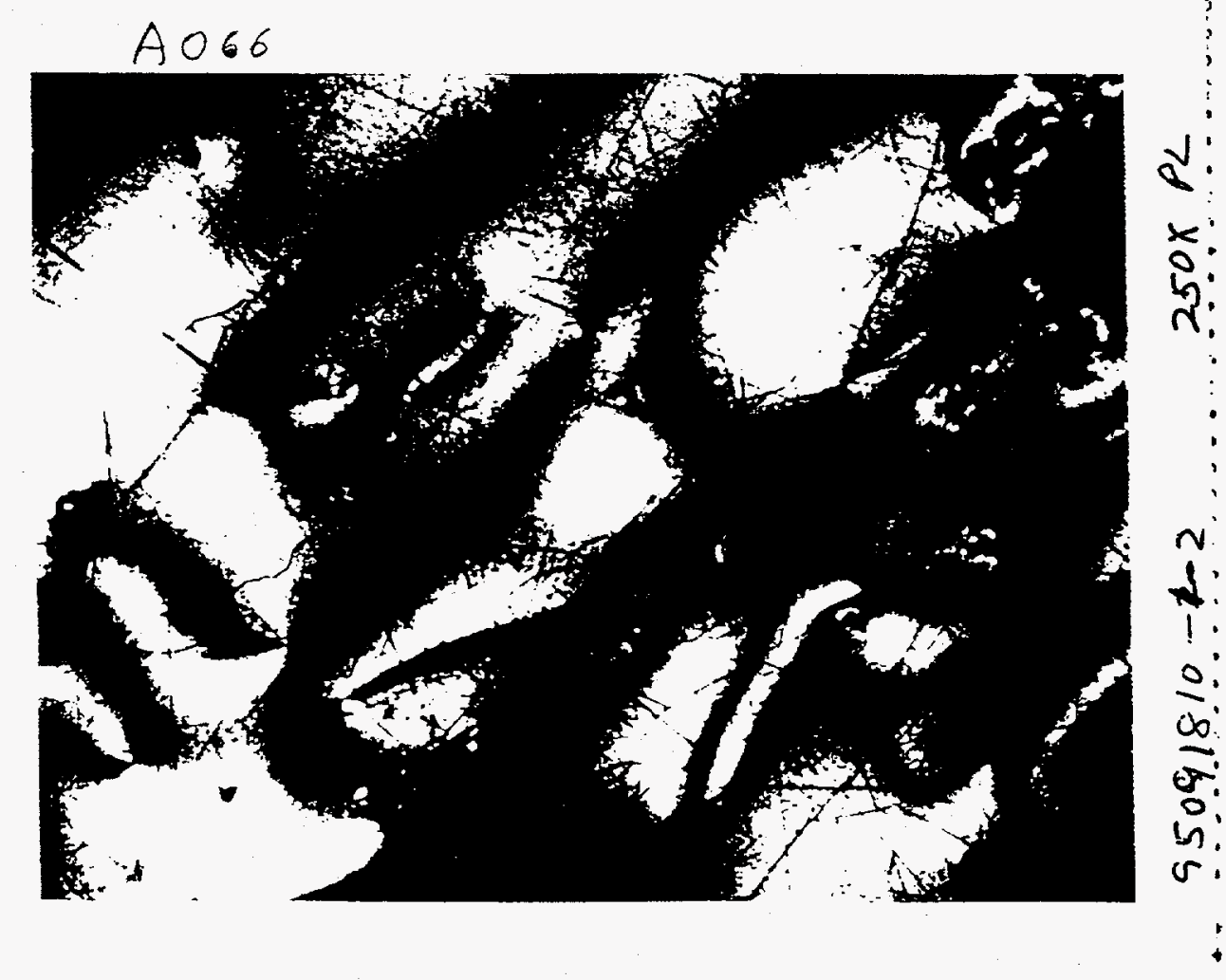

$100 \mu \mathrm{m}$ 
Annealed Mesophase Pitch from Sample A073

$450^{\circ} \mathrm{C}-2 \mathrm{Hr}$, Coal WVGS 13423

A073 $450-24 R \quad 13423$

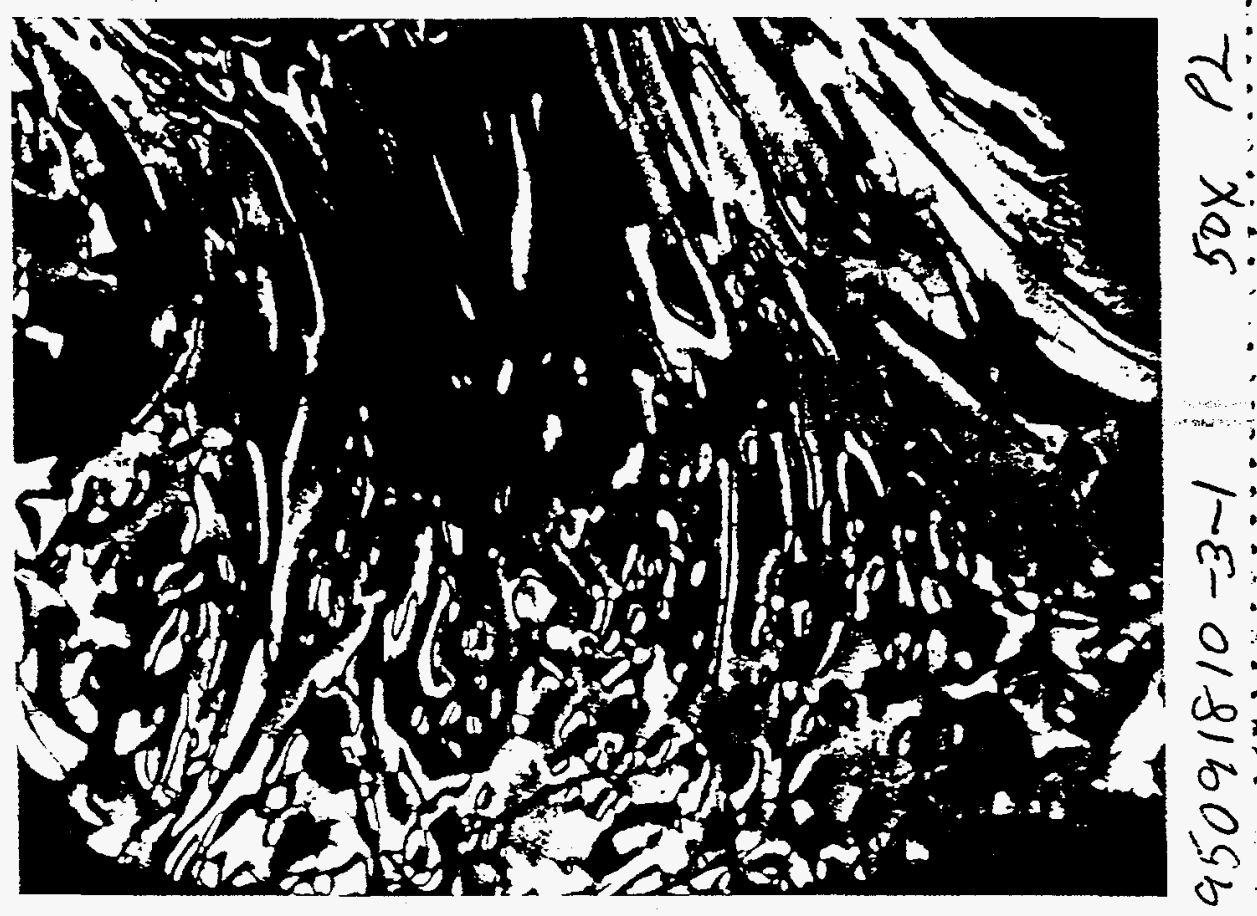

$500 \mu \mathrm{m}$

50X, POLARIZED LIGHT

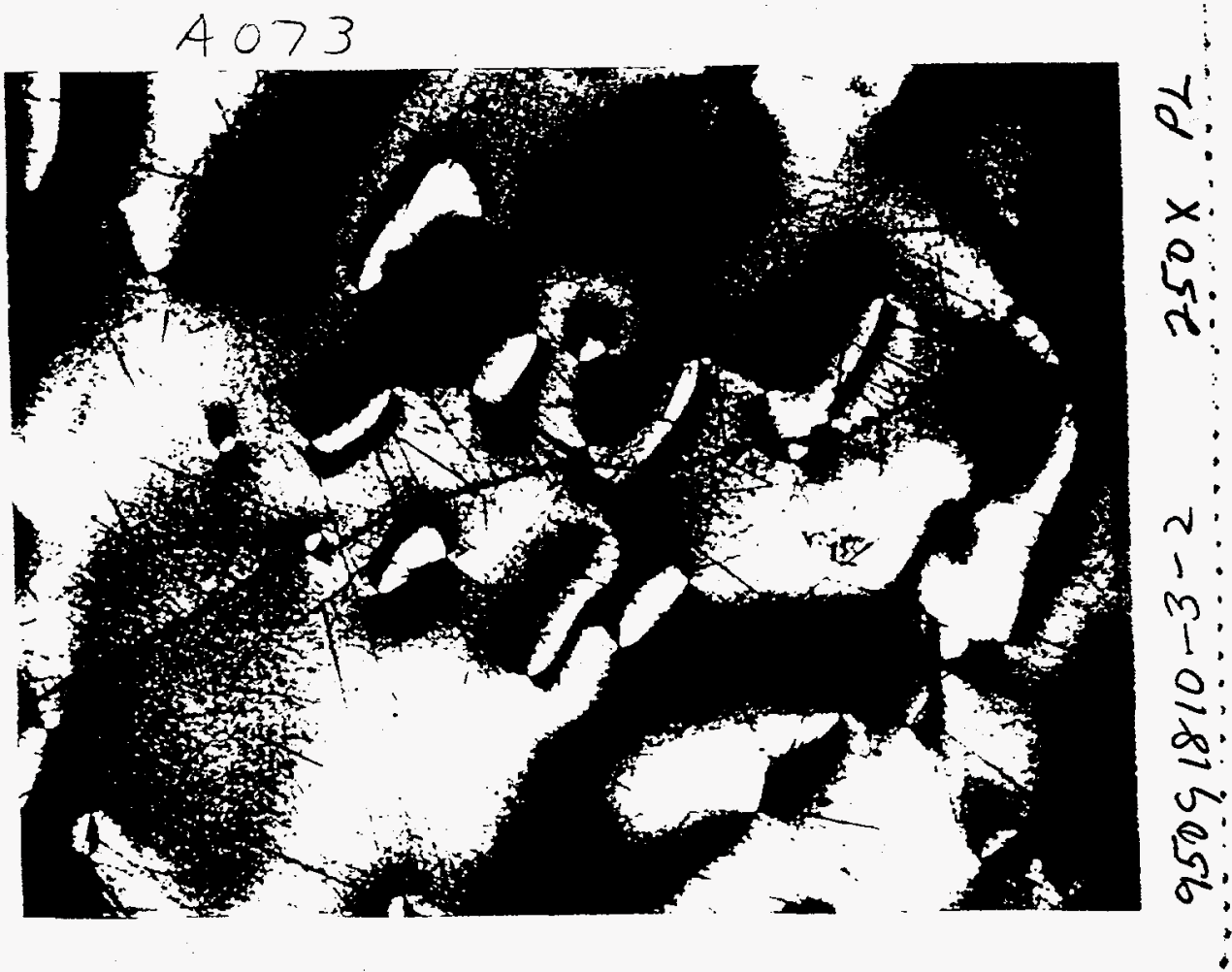

$100 \mu \mathrm{m}$ 
Annealed Mesophase Pitch from Sample A075 $450^{\circ} \mathrm{C}-1 \mathrm{Hr}$., Coal WVGS 13423
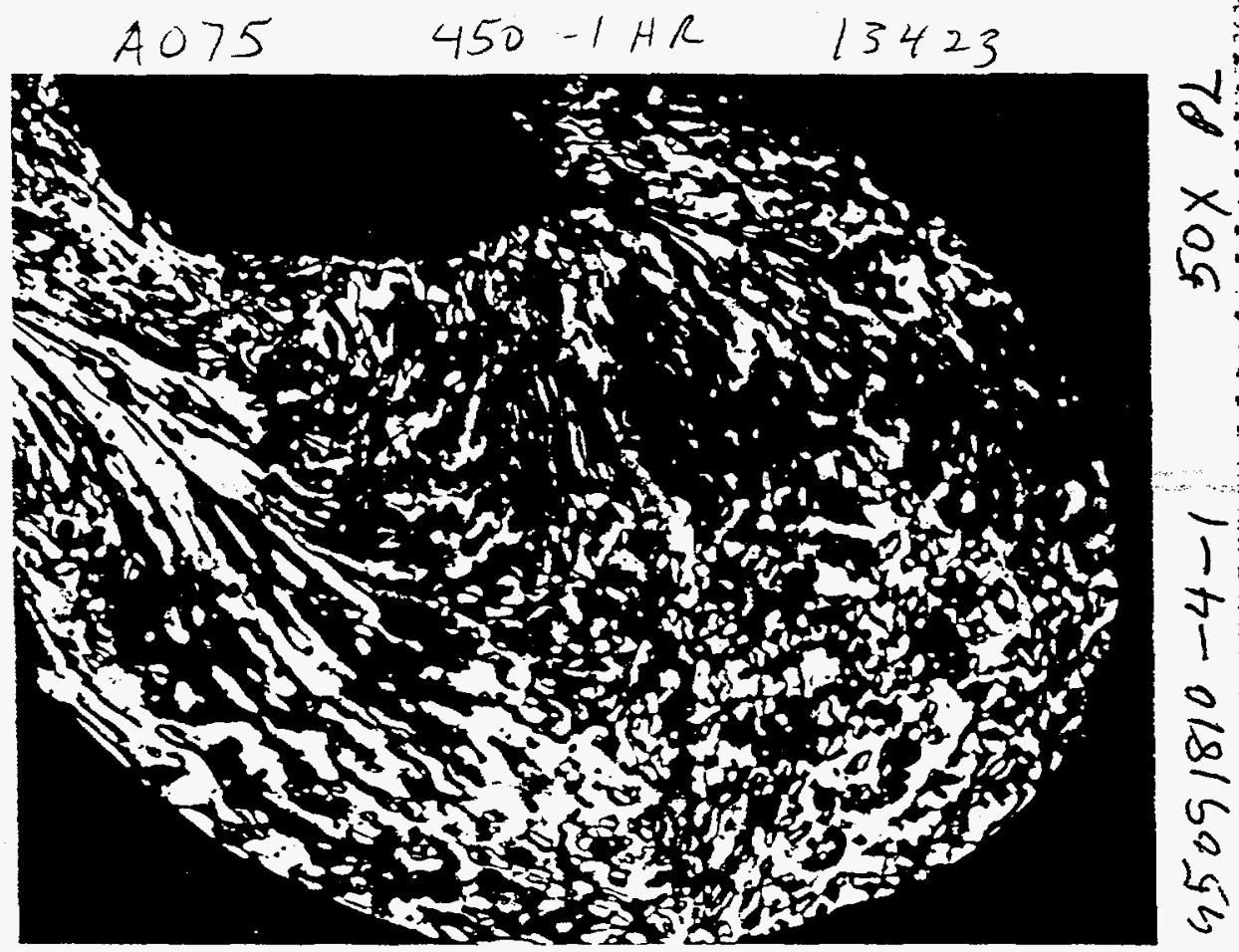

50X, POLARIZED LIGHT

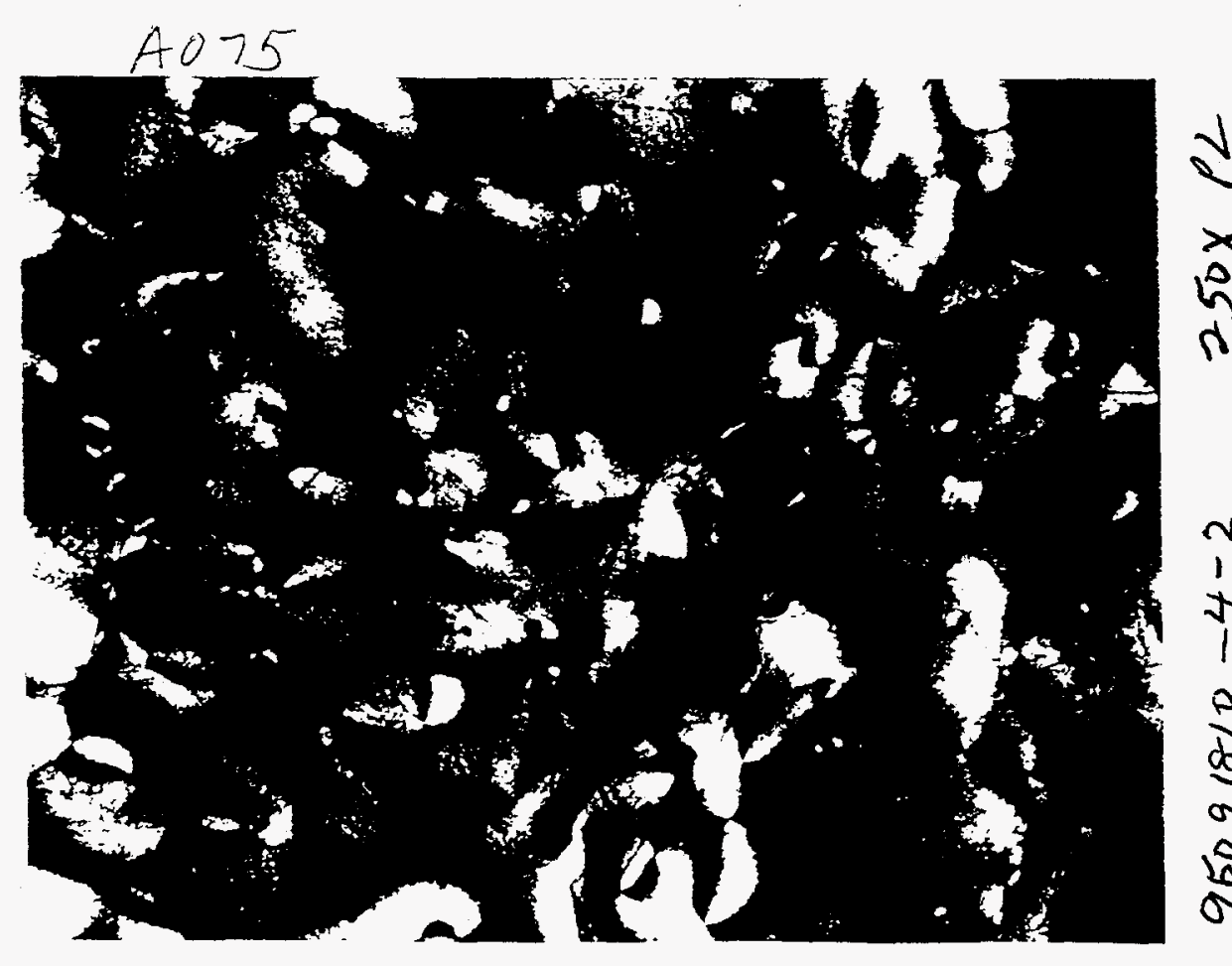


3M COMPANY

Ceramic Materials Department

201-4N-01 3M Center,

St. Paul, MN 55144

M. A. Leitheiser

AIR PRODUCTS AND CHEMICALS

P.O. Box 538

Allentown, PA 18105

S. W. Dean

ALLISON GAS TURBINE DIVISION

P.O. Box 420

Indianapolis, IN 46206-0420

P. Khandelwal (Speed Code W-5)

R. A. Wenglarz (Speed Code W-16)

AMA RESEARCH \& DEVELOPMENT

CENTER

5950 McIntyre Street

Golden, CO 80403

T. B. Cox

ARGONNE NATIONAL LABORATORY

9700 S. Cass Avenue

Argonne, IL 60439

W. A. Ellingson

J. P. Singh

ARGONNE NATIONAL

LABORATORY-WEST

P.O. Box 2528

Idaho Falls, ID 83403-2528

S. P. Henslee

BABCOCK \& WILCOX

Domestic Fossil Operations

20 South Van Buren Avenue

Barberton, OH 44023

M. Gold
BRITISH COAL CORPORATION

Coal Technology Development Division

Stoke Orchard, Cheltenham

Glocestershire, England GL52 4ZG

J. Oakey

CANADA CENTER FOR MINERAL \& ENERGY TECHNOLOGY

568 Booth Street

Ottawa, Ontario

Canada K1A OG1

R. Winston Revic

Mahi Sahoo

DOE

DOE OAK RIDGE OPERATIONS

P.O.Box 2001

Oak Ridge, TN 37831

Assistant Manager for

Energy Research and Development

DOE

DOE OAK RIDGE OPERATIONS

P. O. Box 2008

Building 4500N, MS 6269

Oak Ridge, TN 37831

M. H. Rawlins

DOE

OFFICE OF BASIC ENERGY SCIENCES

Materials Sciences Division

ER-131

19901 Germantowy Road

Germantown, MD 20874-1290

H. M. Kerch

DOE

IDAHO OPERATIONS OFFICE

P. O. Box 1625

Idaho Falls, ID 83415

J. B. Malmo 


\section{DOE}

MORGANTOWN ENERGY TECHNOLOGY CENTER

P.O. Box 880

Morgantown, WV 26505

R. C. Bedick

D. C. Cicero

F. W. Crouse, Jr.

N. T. Holcombe

W. J. Huber

J. E. Notestein

DOE

OFFICE OF FOSSIL ENERGY

FE-72

19901 Germantown Road

Germantown, MD 20874-1290

J. P. Carr

DOE

OFFICE OF VEHICLE AND ENERGY R\&D CE-151 Forrestal Building

Washington, DC 20585

R. B. Schulz

DOE

OFFICE OF SCIENTIFIC AND TECHNICAL INFORMATION

P. O. Box 62

Oak Ridge, TN 37831

For distribution by microfiche as shown in DOE/TIC-4500, Distribution Category:

UC-114 (Coal Based Materials and

Components)

\section{DOE}

PITTSBURGH ENERGY TECHNOLOGY

CENTER

P.O. Box 10940

Pittsburgh, PA 15236
A. L. Baldwin
G. V. McGurl
T. M. Torkos

DOW CORNING CORPORATION

3901 S. Saginaw Road

Midland, MI 48686-0995

H. Atwell

EC TECHNOLOGIES

3614 Highpoint Drive

San Antonio, TX 78217

D. J. Kenton

\section{ELECTRIC POWER RESEARCH}

INSTITUTE

P.O. Box 10412 ,

3412 Hillview Avenue

Palo Alto, CA 94303

W. T. Bakker

J. Stringer

\section{EUROPEAN COMMUNITIES JOINT}

RESEARCH CENTRE

Petten Establishment

P.O. Box 2

1755 ZG Petten

The Netherlands

M. Van de Voorde

GA TECHNOLOGIES. INC.

P.O. Box 85608

San Diego, CA 92138

T. D. Gulden

GAS RESEARCH INSTITUTE

8600 West Bryn Mawr Avenue

Chicago, IL 60631 t

H. S. Meyer

GEORGIA INSTITUTE OF TECHNOLOGY

Materials Science \& Engineering (0245)

Bunger-Henry Building, Room 276

Atlanta, GA 30332-0245

T. L. Starr 
IDAHO NATIONAL ENGINEERING

LABORATORY

P. O. Box 1625

Idaho Falls, ID 83415

B. H. Rabin

LAVA CRUCIBLE-REFRACTORIES CO.

P.O. Box 278

Zelienople, PA 16063

T. Mulholland

LAWRENCE LIVERMORE NATIONAL

LABORATORY

P.O. Box 808, L-325

Livermore, CA 94550

W. A. Steele

LOS ALAMOS NATIONAL LABORATORY

P.O. Box 1663

Los Alamos, NM 87545

J. D. Katz

NATIONAL INSTITUTE OF STANDARDS

AND TECHNOLOGY

U.S. Dept. of Commerce

Bldg. 220, Rm A215

Gaithersburg, MD 20899

S. G. Malghan

\author{
NATIONAL MATERIALS ADVISORY \\ BOARD \\ National Research Council \\ 2101 Constitution Avenue \\ Washington, DC 20418 \\ K. M. Zwilsky
}

OAK RIDGE NATIONAL LABORATORY

P.O. Box 2008

Oak Ridge, TN 37831

P. T. Carlson

N. C. Cole

R. R. Judkins

R. A. Lawson (8 copies)

E. L. Long, Jr.

D. P. Stinton

M. R. Upton

OFFICE OF NAVAL RESEARCH

Code 431,800 N. Quincy Street

Arlington, VA 22217

S. G. Fishman

SANDIA NATIONAL LABORATORIES

Department 6211, MS 0710

Albuquerque, NM 87185

R. J. Buss

G. A. Carlson

A. G. Sault

SHELL DEVELOPMENT COMPANY

P.O. Box 1380

Houston, TX 77251-1380

L. W. R. Dicks

TENNESSEE VALLEY AUTHORITY

Energy Demonstration \& Technology

MR2N58A

Chattanooga, TN 37402-2801

C. M. Huang

THE JOHNS HOPKINS UNIVERSITY

Materials Science \& Engineering

Maryland Hall

Baltimore, MD 21218

R. E. Green, Jr. 
THE MATERIALS PROPERTIES COUNCIL, INC.

United Engineering Center

345 E. Forty-Seventh Street

New York, NY 10017

M. Prager

THE NORTON COMPANY

High Performance Ceramics Division

Goddard Road

Northborough, MA 01532-1545

N. Corbin

THE TORRINGTON COMPANY

Advanced Technology Center

59 Field St.

Torrington, CT 06790

W. J. Chmura

UNION CARBIDE CORPORATION

Linde Division

P.O. Box 44

175 East Park Drive

Tonawanda, NY 14151-0044

Harry Cheung

UNITED TECHNOLOGIES RESEARCH

CENTER

MS 24, Silver Lane

East Hartford, CT 06108

K. M. Prewo

UNIVERSITY OF WASHINGTON

Department of Materials Science and

Engineering

101 Wilson, FB-10

Seattle, WA 98195

T. G. Stoebe

VIRGINIA POLYTECHNIC INSTITUTE \&

STATE UNIVERSITY

Department of Materials Engineering

Blackburg, VA 24601

W. A. Curtin

K. L. Reifsnider
WESTERN RESEARCH INSTITUTE

365 N. 9th Street

P.O. Box 3395

University Station

Laramie, WY 82071

V. K. Sethi

WESTINGHOUSE ELECTRIC CORPORATION

Research and Development Center

1310 Beulah Road

Pittsburgh, PA 15235

S. C. Singhal

?

DR. CAULTON L IRWIN

WEST VIRGNIA UNIVERSTTY

P. O. BOX 6064

MORGANTOWN, WV 26506-6064

JOHN ZONDLO

WEST VIRGINIA UNIVERSITY

P. O. BOX 6102

MORGANTOWN, WV 26506

AL STILLER

WEST VIRGINLA UNIVERSITY

P.O. BOX 6102

MORGANTOWN, WV 26506

DR. T.D. BURCHELL

OAK RIDGE NATIONAL LABORATORY

P.O. BOX 2008 MS 6088

OAK RIDGE, TN 37831-6088 


\section{ATTACHMENT 3}

MOST RECENT WORKSHOP AGENDA 


\section{WORKSHOP ON}

\section{APPLICATIONS OF CARBON PRODUCTS FOR EFFICIENT OPERATION OF HEAVY TRUCKS, BUSES, AND OTHER COMMERCIAL VEHICLES}

The workshop will result in a Multi-Year Program Plan (MYPP) for the U.S. DOE Office of Heavy Vehicle Technologies on long-term research, exploratory development, and implementation of carbon products for heavy vehicle applications.

\section{TENTATIVE AGENDA}

* Designates panel or session moderator.

Wednesday, September 4, 1996

7:30 Continental breakfast

8:00 General introduction to the workshop

8:10 Tom Gross, Deputy Assistant Secretary, U.S. DOE Office of Transportation Technologies: A Vision for Transportation Technologies.

8:30 Jim Eberhardt, Director, U.S. DOE Office of Heavy Vehicle Technologies: Development and Funding Outlook for R\&D Programs on Heavy Vehicle Technologies.

9:15 Panel One: Needs, priorities and bottom line values for trucks, buses and other heavy vehicles: Industry vision and challenges of the future. Goals for the workshop.

- John Leinonen, Failure Analysis Associates, Inc.

Bill Peerenboom, American Trucking Association

Norm Littler, American Bus Association

Louis Kleinstiver, National Truck Equipment Association (invited)

Mark Wilkins, Motor Coach Industries

10:45 Break

11:00 Panel Two: Background on carbon products and composite materials. Experience with carbon composites from defense, aerospace, automobile, and heavy vehicle industries. Examples of new products and processes.

* Dick Ziegler, Advanced Automotive Technologies, ORNL

Alan Taub, Ford Research Lab \& Automotive Composites Consortium

Carol Schutte, NIST Advanced Technology Program

Adi Arieli, Northrop/Advanced Technology Transit Bus

Bob Frankle, Failure Analysis Associates, Inc.

12:30 Lunch 
1:15 Panel Three: On-going truck and bus research, tests, and demonstrations relative to use of carbon products and composite materials for meeting heavy vehicle challenges of the future. Where is heavy vehicle carbon materials work being done and by whom?

V. K. Sharma, Navistar International

Roy Baggerly, PACCAR Technical Center (Invited)

Arie Brouwer, NOVEM, Utrecht, Netherlands

John Shaffer, Center for Manufacturing Technologies, ORNL

Rich Bergstrand, Kenworth Trucks

Gary Rossow, Freightliner (Invited alternate)

\section{2:45 Break}

3:00 Panel Four. Cost and material performance of carbon products relative to metals and other composites. What are new and innovative approaches to reducing the selling price of carbon products while continuing to improve material performance?

- $\quad$ Mike Michno, AMOCO Polymers

Steve Koff, Hardcore/DuPont

Zsolt Rumy, Zoltek

John Weis, DFI Composites

Al Stiller, West Virginia University

Jeremy Hale, Hexel (Invited alternate)

4:30 Distribute and discuss MYPP Outline developed by the Workshop Planning Committee. Assign breakout areas for dinner groupings and day-two breakout sessions.

5:00 Adjourn Day One formal sessions

5:30 Social

7:00 Dinner with groupings according to breakout topics $A, B, C$, and D.

Overview Presentation:

Industrial Carbons and Graphites, John Chang, UCAR Carbon Company

Thursday, September 5, 1996

7:30 Continental breakfast 
8:30 Charge and directions to breakout working groups.

8:45 Breakout sessions:

A. Body, chassis, cargo area, trailers, seat structures, fuel and air tanks, wheel wells, vehicle interior, engine rails, other structural members;

* $\quad$ Mike Scotese, Mack Truck

Ever Barbero, WVU

B. Crash protection components, energy absorbing materials, bumpers and impact guards (front, rear, and side), vehicle crashworthiness, fire protection components;

* Victor Suski, American Trucking Association

Sotiris Kellas, NASA Langley Research Center

C. Running gear: brakes, clutches, suspension, axles, wheels, steering components;

* Larry Stoneburner, Dana Corporation (Invited)

Tim Burchell, Carbon and Insulation Materials, ORNL

D. Power train: engine components, drive shafts, radiators, transmissions.

Chuck Jones, Dana Corporation

Each breakout group addresses the following questions:

1. Current state of the art and cost-benefit outlook for making the components from carbon/composite materials? Manufacturability? Raw material and processing costs?

2. Effect of material properties on ride, handling, and general performance of heavy vehicles? Damping characteristics of carbon products. Flammability and smoke toxicity properties of carbon products? Insulation properties (thermal and acoustic) of carbon products? Compatibility of carbon materials with fuels, temperatures, etc.?

3. Cost-performance thresholds to be achieved, i.e., what performance levels are you willing to pay for?

4. Environmental issues, recyclability, disposability?

10:30 Break 
11:00 Breakout sessions resume and address the following:

5. R\&D needed on fabrication, product manufacture, product development, material development?

6. R\&D needed on overall vehicle systems design and manufacture?

7. Other R\&D needs? Test beds and demos needed?

12:00 Each breakout group determines their top ten long-term $R \& D$ needs. Breakout group results are put into MYPP form for discussion in afternoon plenary session.

12:30 Lunch

12:50 Luncheon speaker: Congressional Views on R\&D Funding (Invited)

2:00 Plenary Session

* Sid Diamond, U.S. DOE Office of Heavy Vehicle Technologies

All breakout session moderators

Breakout session moderators will explain and justify their groups' recommendations.

Discussion by all participants of findings, recommendations, and possible omissions of other high priority R\&D objectives.

3:15 Wrap-up discussion

4:00 Conclusion of workshop

Draft MYPP to be sent to all participants by end of September for comment.

Final MYPP recommendation submitted to U.S. DOE Office of Heavy Vehicle Technologies.

CARL6:HVPROGA.WPD 
ATTACHMENT 4

JACK WHITE LETTER 
June 27, 1996

Jack L. White

Chair, American Carbon Society

Department of AMES

University of California, San Diego

La Jolla, CA 92957-0411

Dear Professor White:

This is to confirm our interest in organizing an American Carbon Society workshop for the May-June, 1998 time-frame on the general topic of the role of carbon products in critical

industries of the future. An intent of the proposed workshop is to elevate the status of carbon materials as a principal crosscutting technology. Positioning carbon products in such a manner will help ensure continued support for carbon materials R\&D.

One such slate of industries, as designated by the U.S. DOE office of Industrial Technologies (OIT), includes steel, aluminum, glass, metals casting, chemicals, refining, and forest products. The OIT selected these "Industries of the Future" based on their rather high consumption of energy, level of pollution, and low ratio of $R \& D$ expenditures to total sales.

The proposed ACS workshop would not be limited to the above seven industries, but would certainly include some of them. Based on our preliminary discussions with the OIT, we would expect a good bit of synergy between the proposed ACS workshop and on-going OIT programs, especially since advanced materials is an orT designated cross-cut technology.

There would also be significant synergy with the Carbon Products Consortium (CPC), an industry, government, university cooperative $R \& D$ organization which includes, UCAR Carbon, Koppers Industries, CONOCO, ALCOA, AMOCO POlymers, and West Virginia University. ORNL, Eiber Materials Inc., and BASE Corp are affiliates of the CPC.

We would foresee the workshop being a two and one-half day program with plenary speakers and panels, and possibly breakout groups meeting in parallel which would reconvene in plenary session to report results. We think there are at least four general themes which would be of concern to the carbon products industry: 1) feedstock/raw material quality, supply, and domestic availability; 2) loss of American carbon manufacturing 
capability to off-shore interests; 3) pressure to produce carbon products at lower costs while improving material performance; 4) transfer and implementation of technology from research labs to commercial application.

Regarding topic one, some attention would be given to recent developments obtained through CPC programs on coal-based feedstocks for carbon products.

Conference facilities are available at West virginia University in the recently constructed National Research Center for Coal and Energy. A broad range of housing is available in the Morgantown area from lower-cost campus housing to resort style accommodations with golf courses, health clubs, and other amenities.

A tentative agenda for the workshop is enclosed. We propose to cover five categories of industrial users of carbon products, but would focus on the four themes mentioned above within each industrial category.

Thank you for considering our workshop proposal. We would look forward to working with you, Bill Nystrom, Tim Burchell and others to develop further details of the workshop.

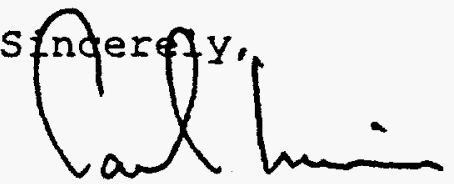

Caulton I. Irwin

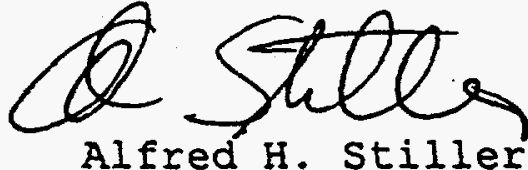

Alfred $\mathrm{H}$. Stiller

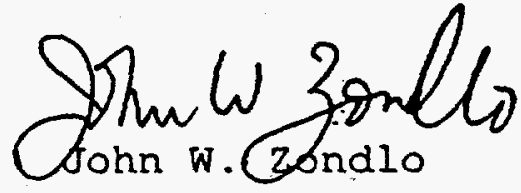

enc.

X.C. William A. Nystrom

Timothy D. Burchell 